This is the final peer-reviewed accepted manuscript of:

Montanari, S.; Scalvini, L.; Bartolini, M.; Belluti, F.; Gobbi, S.; Andrisano, V.; Ligresti, A.; Di Marzo, V.; Rivara, S.; Mor, M.; Bisi, A.; Rampa, A. Fatty Acid Amide Hydrolase (FAAH), Acetylcholinesterase (AChE), and Butyrylcholinesterase (BuChE): Networked Targets for the Development of Carbamates as Potential Anti-Alzheimer's Disease Agents. J. Med. Chem. 2016, 59 (13), 6387-6406.

The final published version is available online at:

https://doi.org/10.1021/acs.jmedchem.6b00609.

Rights / License:

The terms and conditions for the reuse of this version of the manuscript are specified in the publishing policy. For all terms of use and more information see the publisher's website.

This item was downloaded from IRIS Università di Bologna (https://cris.unibo.it/)

When citing, please refer to the published version. 


\section{Fatty acid amide hydrolase (FAAH), acethylcholinesterase (AChE) and butyrylcholinesterase (BuChE): networked targets for the development of carbamates as potential anti Alzheimer's Disease agents}

Serena Montanari,${ }^{1 \dagger}$ Laura Scalvini, ${ }^{2}$ Manuela Bartolini, ${ }^{1}$ Federica Belluti, ${ }^{1}$ Silvia Gobbi, ${ }^{1}$ Vincenza Andrisano, ${ }^{3}$ Alessia Ligresti, ${ }^{4}$ Vincenzo Di Marzo, ${ }^{4}$ Silvia Rivara,${ }^{2}$ Marco Mor, ${ }^{2}$ Alessandra Bisi, ${ }^{1}$ Angela Rampa ${ }^{1 *}$

${ }^{1}$ Department of Pharmacy and Biotechnology, Alma Mater Studiorum University of Bologna, Via Belmeloro 6, 40126 Bologna, Italy; ${ }^{2}$ Department of Pharmacy, University of Parma, Parco Area delle Scienze 27/A, 43124 Parma, Italy; ${ }^{3}$ Department for Life Quality Studies, Alma Mater Studiorum University of Bologna, Corso d'Augusto 237, 47921 Rimini, Italy; ${ }^{4}$ Endocannabinoid Research Group, Institute of Biomolecular Chemistry, National Research Council, Via Campi Flegrei 34, 80078 Pozzuoli, NA, Italy. 
Abstract. The modulation of the endocannabinoid system is emerging as a viable avenue for the treatment of neurodegeneration, being involved in neuroprotective and anti-inflammatory processes. In particular, indirectly enhancing endocannabinoid signaling to therapeutic levels through FAAH inhibition might be beneficial for neurodegenerative disorders such as Alzheimer's disease, effectively preventing or slowing the progression of the disease. Hence, in the search for a more effective treatment for Alzheimer's disease, in this paper, the multi-target-directed ligand paradigm was applied to the design of carbamates able to simultaneously target the recently proposed endocannabinoid system and the classic cholinesterase system, and achieve effective dual FAAH/cholinesterase inhibitors. Among the two series of synthesized compounds, while some derivatives proved to be extremely potent on a single target, compounds $\mathbf{9}$ and $\mathbf{1 9}$ were identified as effective dual FAAH/ChE inhibitors, with well-balanced nanomolar activities. Thus, 9 and 19 might be considered as new promising candidates for Alzheimer's disease treatment. 


\section{Introduction}

The progressive aging of the population in western countries undoubtedly reflects the continuous improvements in living conditions. Consequently, an increase in age-related diseases, among which Alzheimer's Disease (AD) plays a primary role, is being observed, and a growing trend can be anticipated for the coming years. ${ }^{1}$

$\mathrm{AD}$ is characterized by progressive mental deterioration, associated with degeneration of brain regions involved in superior cognitive functions. The neuropathological hallmarks include extracellular deposition of amyloid- $\beta$ peptides $^{2}$ to form $A \beta$ plaques, intraneuronal accumulation of aberrant forms of hyperphosphorylated tau $\operatorname{protein}^{3}$ (neurofibrillary tangles), as well as synapse dysfunction and neuronal loss. ${ }^{4}$ In this scenario, information transfer at synapses begins to fail, the number of synapses declines, and neurons eventually die. ${ }^{5}$

The major pathological changes in $\mathrm{AD}$ involve cholinergic nerve pathways, from the frontal base to the cerebral cortex and hippocampus, associated with attention, learning ability, task and memory related activities, and other cognitive processes. The loss of basal forebrain cholinergic neurons leads to reduction of the cholinergic tone, and memory and cognitive deficits which are characteristic of this disease. ${ }^{6}$ Acetylcholinesterase inhibitors (AChEIs) boost cholinergic neurotransmission in forebrain regions by preventing the breakdown of acetylcholine (ACh), and temporary ameliorate the clinical condition. Mammal brain contains two major forms of cholinesterases (ChEs), acetylcholinesterase (AChE) and butyrylcholinesterase (BuChE). In healthy brain, AChE is the major actor in ACh breakdown. Conversely, in AD affected brain, BuChE levels and activity progressively rise, while AChE activity declines. Therefore, both enzymes are likely to be involved in the regulation of ACh central levels in AD patients and represent validated therapeutic targets to counteract the cholinergic deficit. ${ }^{7,8}$ 
Currently approved AD treatments only provide temporary and modest improvement in cognitive functions, through cholinergic and antiglutamatergic mechanisms, but they cannot significantly modify the course and the ultimate outcome of the disease. Thus, there is an urgent need for disease-modifying therapies to fight the upcoming Alzheimer's disease epidemic.

Over the past two decades, neuroinflammation has emerged as an integral process in the pathogenesis of $\mathrm{AD}$. Post-mortem analysis of the brains of $\mathrm{AD}$ patients has revealed an increased amount of activated microglia and astrocytes as well as significantly higher levels of proinflammatory cytokines, namely IL-1, IL-6 and TNF- $\alpha$, and reactive oxygen species (ROS). ${ }^{9}$ Microglia represent brain's innate immune system, hence the first line of defense against invading pathogens. However, microglial activation may also be evoked by endogenous proteins and can significantly contribute to neuronal damage. Indeed, inflammatory changes are observed at the amyloid deposits, which are rich in activated microglia. Once stimulated, the microglia release a wide variety of pro-inflammatory mediators that contribute to neuronal dysfunction and eventually result in cell death. These mediators create and feed a vicious cycle that may play an important role in the pathological progression of $\mathrm{AD} .{ }^{10}$ When activated, microglia cells may also recruit astrocytes that actively enhance the inflammatory response to extracellular $\mathrm{A} \beta$ deposits. Moreover, reactive microglia play an important role in governing the expression of $A \beta$ and tau, with a positive feedback mechanism that drives disease progression.

The modulation of the endogenous cannabinoid system (ECS) is now emerging as a potentially viable option for the treatment of neurodegeneration. ECS is composed of the endocannabinoid signaling molecules, including anandamide ( $N$-arachidonoylethanolamine, AEA) and 2arachidonoyl glycerol (2-AG), their $\mathrm{G}$ protein-coupled cannabinoid receptors $\mathrm{CB}_{1}$ and $\mathrm{CB}_{2}$, and enzymes for endocannabinoid biosynthesis and inactivation. $\mathrm{CB}_{1}$ receptors are highly expressed at the terminals of central and peripheral neurons, where they regulate neurotransmitter release. $\mathrm{CB}_{2}$ receptor expression is associated with the peripheral immune system and microglia during 
neuroinflammation. ${ }^{11}$ Endocannabinoids are lipid compounds of the eicosanoid family, derived from the processing of membrane phospholipids, and are synthesized on-demand in response to (patho)physiological stimuli. Two specific enzymes are mostly responsible for their degradation: fatty acid amide hydrolase (FAAH) and monoacylglycerol lipase (MAGL), which metabolize AEA and 2-AG, respectively. ${ }^{12}$ Endocannabinoid signaling has been found to be altered in many neurodegenerative disorders including $\mathrm{AD}$, in which AEA levels are decreased and are inversely correlated with those of $\mathrm{A} \beta \cdot{ }^{13}$ In $\mathrm{AD}$ brain, the expressions of $\mathrm{CB}_{2}$ receptors in microglia and of FAAH in astrocytes are increased, as a response to the inflammatory processes typical of the disease. ${ }^{14}$ Since AEA is a substrate for FAAH, the higher levels of this enzyme in astrocytes surrounding neuritic plaques suggest that these cells, via FAAH, might be responsible for the lower levels of $\mathrm{AEA}$ and the decreased neuroprotection promoted by AEA activation of $\mathrm{CB}_{1}$ and $\mathrm{CB}_{2}$ receptors. FAAH inhibition might therefore be beneficial in preventing or reducing the inflammatory process associated with $\mathrm{A} \beta$ deposition, by indirectly enhancing endocannabinoid signaling to therapeutic levels, and might be considered an attractive therapeutic avenue, adding a new piece to the Alzheimer's puzzle.

For the treatment of disorders involving multiple and complex pathways such as AD, a drug endowed with a single-target mechanism of action may not be the most effective agent. In this case, polypharmacy, that is the synergistic delivery of a "cocktail" of two or more drugs, may give enhanced beneficial effects and potentially lead to disease modification. However, poor patient compliance and pharmacokinetic interferences are negative aspects potentially associated with such an approach. Alternatively, a single therapeutic agent could be purposely designed to interact with different targets and/or systems involved in the onset or progression of the disease. This multi-target approach would allow attacking the disease from many sides, thus greatly enhancing the probability of disease modification. ${ }^{15,16}$ 
Taking into account these elements, we tried to tackle AD's multifaceted nature using the multitarget-directed ligand (MTDL) paradigm, thus combining our long lasting experience in the design of inhibitors of classic AD targets with the attempt to hit the ECS. In this respect, we recently reported compound 1 (Figure 1) as first dual ChE/FAAH inhibitor, with activity in the nanomolar range. ${ }^{17}$ In this paper, appropriately designed modifications were performed on lead molecule $\mathbf{1}$ in order to increase potency and obtain well-balanced activities on the selected targets, namely FAAH, $\mathrm{AChE}$ and BuChE. In particular, to explore the chemical space of these enzymes and to determine the structural features required for high potencies, various carbamic functions were inserted in selected oxygenated heterocycles, related to natural products and considered as privileged structures, with spacer chains of different length (Figure 1). As a result, a first small library of 16 compounds (2-17) was synthesized and tested for activity against AChE, BuChE, and FAAH. Furthermore, a new series of eight compounds (18-25, Figure 1) was designed and synthesized by inserting a triazole ring in the spacer chain, to evaluate the impact of a lower flexibility and the importance of the basic center for biological activities.<smiles>CN(CCCOc1ccc2ccc(=O)oc2c1)Cc1cccc(OC(=O)NCCCCCc2ccccc2)c1</smiles><smiles>CCI</smiles>

1<smiles>[R]NC(=O)Oc1cccc(CN(C)CCCC(C)O[Al])c1</smiles><smiles>[R]NC(=O)Oc1cccc(OCC)c1Cn1cc(COc2ccc3ccc(=O)oc3c2)nn1</smiles> 
Figure 1. Structure of lead compound 1 and design strategies for the studied compounds, involving the introduction of flexible and rigid spacers. Ar represents a variety of substituted heterocycles and $\mathrm{R}$ represents alkyl and phenyl alkyl substituted groups.

\section{Chemistry}

The synthetic procedures to obtain non commercially available hydroxycoumarins (Ar-OH) are reported in the supporting information (SI, scheme 1S). The synthesis of compounds 2-17 was accomplished as shown in Scheme 1. The hydroxy group of the naturally inspired heterocycles was alkylated with 1-bromo-3-chloropropane or 1-bromo-5-chloropentane, in the presence of $\mathrm{K}_{2} \mathrm{CO}_{3}$, to afford the chloroalkoxy derivatives $\mathbf{2 6 - 3 7}$. These intermediates were then reacted with NaI to obtain the iodinated analogues (38-49), more reactive species for the following nucleophilic substitution, that was accomplished by refluxing $N, N$-(3-hydroxybenzyl)-methylamine, ${ }^{18}$ compounds 38-49 and TEA in refluxing toluene to obtain compounds 50-61. Finally, compounds 50-61 were treated with the selected isocyanate, in the presence of $\mathrm{NaH}$, to give the desired compounds $\mathbf{2 - 1 7}$. The synthetic procedures to obtain the isocyanate not yet described in literature were reported in the SI (schemes $2 \mathrm{~S}$ and $3 \mathrm{~S})$.

Scheme 1. ${ }^{a}$ Synthesis of compounds 2-17.
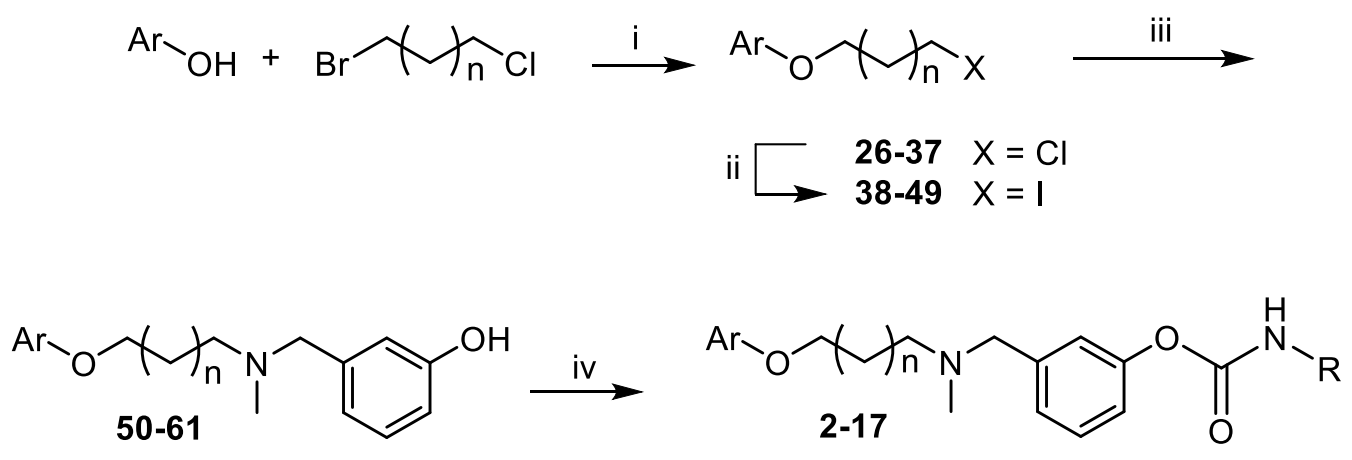
${ }^{a}$ Reagents and conditions: i) $\mathrm{K}_{2} \mathrm{CO}_{3}$, acetone, reflux, 10h; ii) NaI, MeCOEt, reflux; 3h iii) $N$-(3hydroxybenzyl)methylamine, TEA, toluene, reflux, 20h; iv) RNCO, NaH, toluene, rt, $24 \mathrm{~h}$.

According to Scheme 2, compounds 18-25 were synthesized starting from 7-hydroxycoumarin, which was reacted with propargyl bromide obtaining 62. Then, the 1,2,3-triazole framework was introduced via a click chemistry reaction (Huisgen 1,3-dipolar cycloaddition), in which the alkyne was reacted with the selected azides, in the presence of $\mathrm{CuSO}_{4}$ and sodium ascorbate to obtain $\mathbf{6 3 a}, \mathbf{b}$. The synthetic procedures for achieving the azides are reported in the SI (scheme 4S). Subsequently, the methoxy group of $\mathbf{6 3 a}, \mathbf{b}$ was removed by treatment with $\mathrm{BBr}_{3}(\mathbf{6 4 a}, \mathbf{b})$. When tert-butyl dimethylsilane was employed as protecting group, the free phenolic oxygen $(\mathbf{6 5 a}, \mathbf{b})$ was obtained during purification via flash chromatography. Finally, compounds 64a,b and 65a,b were combined with the appropriate isocyanate to afford the final carbamates 18-25.

Scheme 2. ${ }^{a}$ Synthesis of compounds 18-25. 

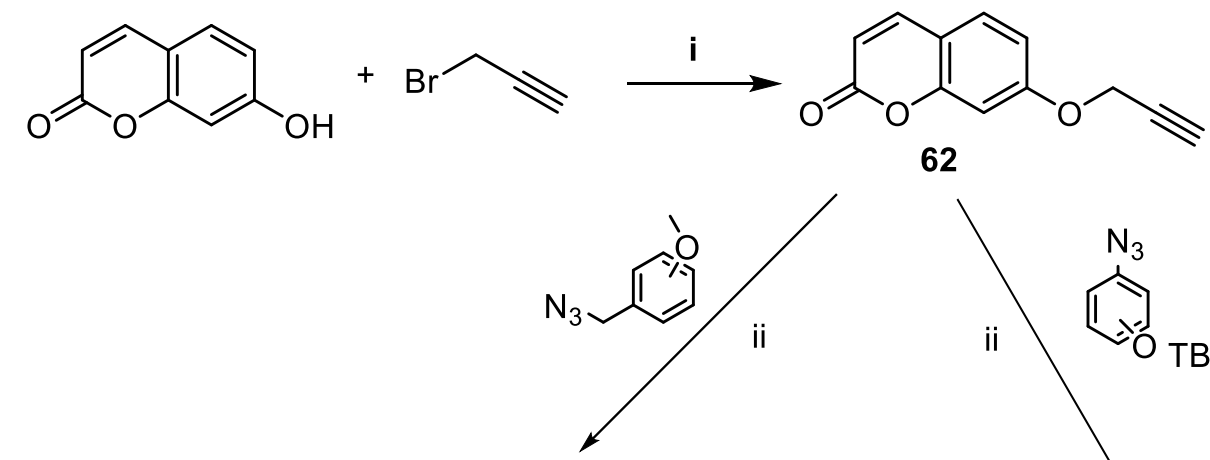<smiles>COc1ccc(Cn2cc(COc3ccc4ccc(=O)oc4c3)nn2)cc1</smiles><smiles></smiles><smiles>CC(C)(C)Oc1ccc2ccc(=O)oc2c1</smiles><smiles>O=c1ccc2ccc(OCc3cn(C4=CC5CCC(O4)C5O)nn3)cc2o1</smiles><smiles></smiles><smiles>[R]NC(=O)Oc1ccccc1Cn1cc(COc2ccc3ccc(=O)oc3c2)nn1</smiles><smiles>[R]NC(=O)Oc1cccc(-n2cc(COc3ccc4ccc(=O)oc4c3)nn2)c1</smiles>

${ }^{a}$ Reagents and conditions: i) $\mathrm{K}_{2} \mathrm{CO}_{3}$, acetone, reflux, 8h; ii) TEA, selected azide, $\mathrm{CuSO}_{4}$, sodium ascorbate, DMSO, rt, 24h; iii) $\mathrm{BBr}_{3}, \mathrm{DCM}, \mathrm{N}_{2}$ atmosphere, rt, 48h; iv) Silica gel (flash chromatography); v) RNCO, NaH, toluene, rt, 24h.

\section{Results and discussion}

Cholinesterase inhibition by compounds 2-17. 
The activities of the newly synthesized compounds 2-17 were evaluated against human recombinant AChE ( $h \mathrm{AChE})$ and BuChE from human serum $(h \mathrm{BuChE})$, using the method of Ellman ${ }^{19}$ and the inhibitory potencies, expressed as $\mathrm{IC}_{50}$ values, are reported in Table 1.

Inhibition values for compound $\mathbf{1}$ and rivastigmine, the only marketed carbamate drug approved for AD treatment, are also listed in Table 1 for comparison. Due to the presence of a carbamic residue, ${ }^{20,21}$ all compounds showed a time-dependent ChEs inhibition.

Regarding AChE inhibitory activity, different results were observed maintaining the same carbamic substituent of $\mathbf{1}$ and varying the substitution pattern on the coumarin scaffold (2-8). The introduction of a methyl group on the 4-position of the coumarin scaffold (compound 2), and its extension to a cyclohexane ring (compound 3), did not significantly alter the inhibitory activity with respect to the lead $\mathbf{1}$. A lower potency was observed for the corresponding derivative $\mathbf{4}$, in which an aromatic ring was introduced on the coumarin lactone ring. The introduction of an aryl moiety in position 3 of the coumarin was also detrimental (5-8), especially when a chlorine atom was introduced in the para position (compound 8). Therefore, the simple coumarin core of the lead $\mathbf{1}$ was maintained and the phenylpenthyl carbamic function was varied, introducing heptyl (9), hexylphenyl (12) and phenylhexyl (13) groups. A slight decrease in potency was observed for compound 13, bearing an additional methylene unit with respect to $\mathbf{1}$. Compound $\mathbf{9}$, with a linear heptyl chain, proved to be the most potent of the series $\left(\mathrm{IC}_{50}=37.4 \mathrm{nM}\right)$, being twice as potent as $\mathbf{1}$. The presence of a phenyl ring directly bound to the carbamate nitrogen, as in compound $\mathbf{1 2}$, led to a remarkable reduction in potency (two orders of magnitude). Afterwards, in an attempt to improve potency, the heptyl carbamic function was introduced on the heterocycles that showed a comparable activity, namely 7,8,9,10-tetrahydro-6H-benzo [c] chromen-6-one in this series and azaxanthone in a previously reported paper. ${ }^{17}$ This modification led to an increased inhibitory activity (10 vs $\mathbf{3}$, IC 50 $=21.6 \mathrm{vs} 89.9 \mathrm{nM}$, and $11 \mathrm{vs}$ the previously reported azaxanthone $\left.{ }^{17} \mathrm{IC}_{50}=13.0 \mathrm{vs} 89.5 \mathrm{nM}\right)$. Finally, for 9-11, the elongation of the alkoxy chain from three to five methylene units provided a 
remarkable increase in potency, being compounds $\mathbf{1 5 - 1 7}$ the most potent of the series, while for compound 1 chain elongation (14) essentially allowed to maintain the original potency.

All the tested compounds 2-17 turned out to inhibit $h \mathrm{BuChE}$ more effectively than $h \mathrm{AChE}$, with $\mathrm{IC}_{50}$ values within a close inhibition range (from 0.27 to $\left.3.51 \mathrm{nM}\right)$, except for derivative $12\left(\mathrm{IC}_{50}=\right.$ 32.1 nM). In particular, compounds $\mathbf{1 0 - 1 1}$ and $\mathbf{1 5 - 1 7}$ proved to be the most potent BuChE inhibitors in the series with inhibitory activities in the subnanomolar range.

Table 1. Inhibitory activity against $h \mathrm{AChE}, h \mathrm{BuChE}$ and $r \mathrm{FAAH}, \mathrm{IC}_{50}$ values of the studied compounds and of the commercial anti-AD drug Rivastigmine (Riva). 


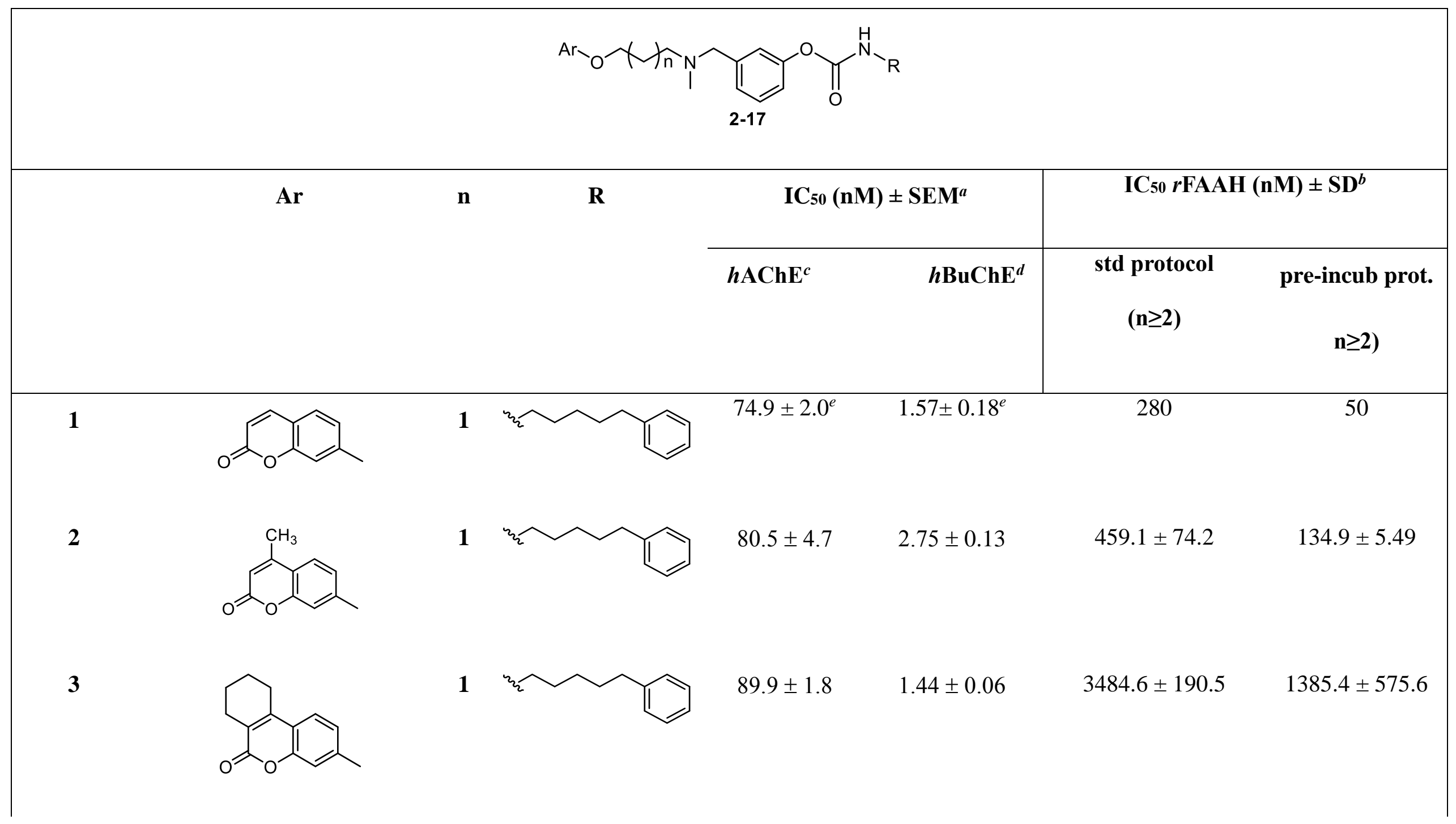




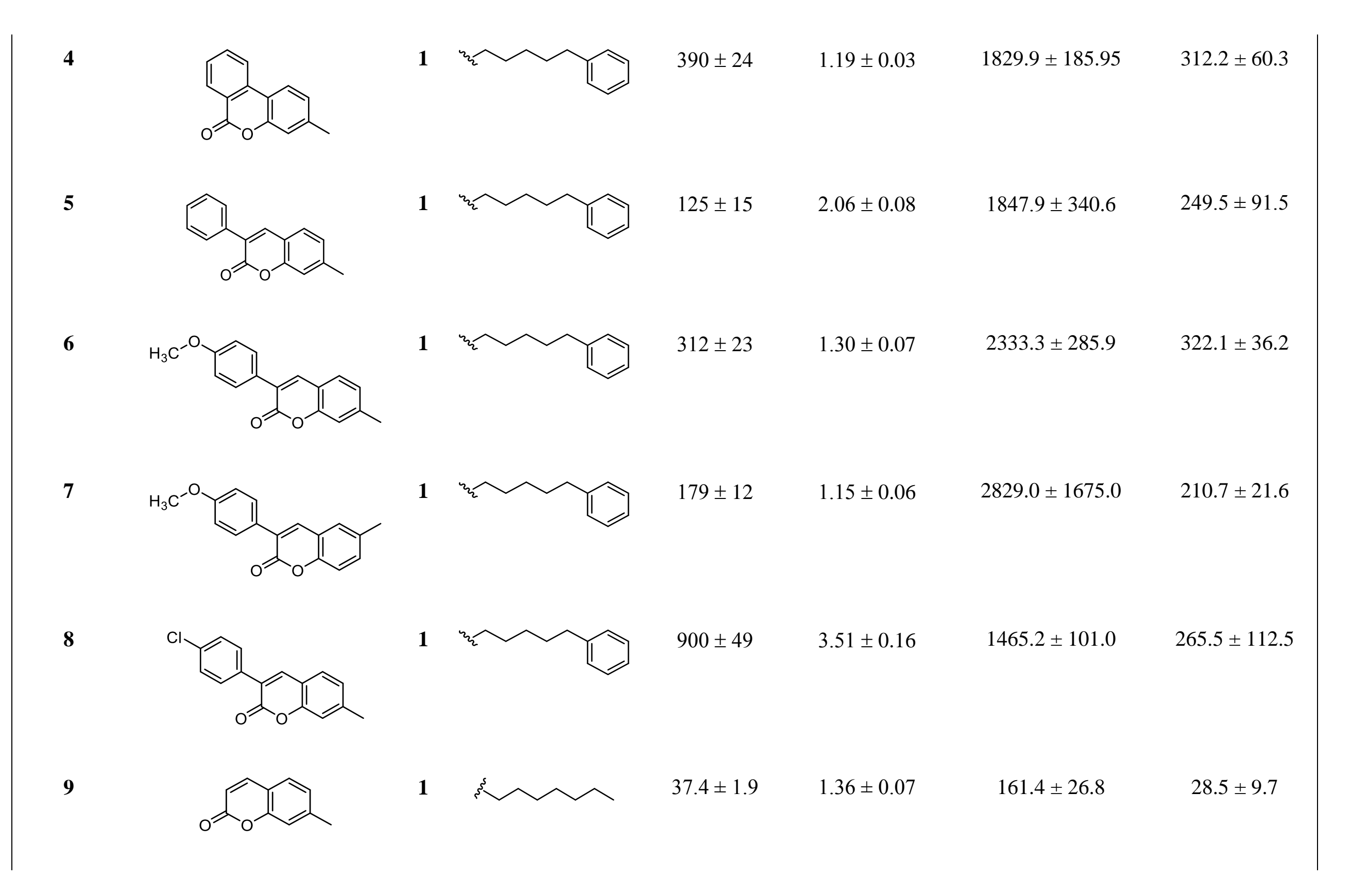


10<smiles>Cc1ccc2c3c(c(=O)oc2c1)CCCC3</smiles>

$121.6 \pm 0.7 \quad 0.27 \pm 0.01 \quad 2487.4 \pm 886.5$

1

ร

12<smiles>Cc1ccc2ccc(=O)oc2c1</smiles>

13<smiles>Cc1ccc2ccc(=O)oc2c1</smiles>

14<smiles>Cc1ccc2ccc(=O)oc2c1</smiles>

15<smiles>Cc1ccc2ccc(=O)oc2c1</smiles>

16<smiles>Cc1ccc2c3c(c(=O)oc2c1)CCCC3</smiles>

1

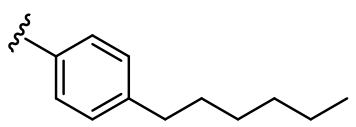

$3800 \pm 540$

1 1 $109 \pm 5$

3

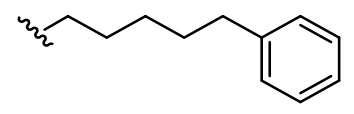

$88.1 \pm 4.0$

3 ร

3

$11.3 \pm 4.9$

凰

$18.3 \pm 0.8$
$13.0 \pm 0.6$

$0.69 \pm 0.02$
$32.1 \pm 2.9$

$2.85 \pm 0.14$

$1.23 \pm 0.10$

$0.79 \pm 0.04$
$>50000$

$1792.2 \pm 283.9$

$798.1 \pm 222.4$

$1288.7 \pm 352.3$

$3134.0 \pm 980.9$

$>50000$

$529.7 \pm 166.5$

$120.2 \pm 38.5$

$241.9 \pm 38.0$

$767.4 \pm 110.8$

$109.1 \pm 6.1$ 
17

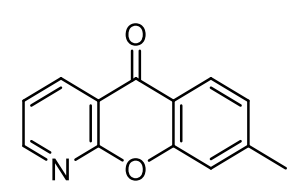

3

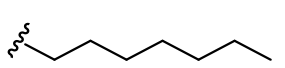

$6.92 \pm 0.58$

$0.53 \pm 0.03$

$2177.1 \pm 419.0$

$178.3 \pm 15.1$

Riva

$1535 \pm 64^{f} \quad 301 \pm 14^{f}$

${ }^{a}$ Human recombinant $\mathrm{AChE}$ and $\mathrm{BuChE}$ from human serum were used. ${ }^{b} \mathrm{FAAH}$ from rat brain membranes was used. IC 50 values represent the concentration of inhibitor required to decrease enzyme activity by $50 \%$ and are the mean of two/three independent measurements, each performed in duplicate. $\mathrm{SEM}=$ standard error of the mean. ${ }^{c} \mathrm{IC}_{50}$ values of all derivatives but $\mathbf{1 2}$ were determined using a 120 min-incubation period; for 12 a 60 min-incubation period was used, according to the inhibition kinetics. ${ }^{d} \mathrm{IC}_{50}$ values of all derivatives were determined using 15 or 20 min incubation, according to the inhibition kinetics. ${ }^{e}$ Data from reference. ${ }^{17}$ Data from reference. ${ }^{22}$ 
It is well known that the kinetics of ChE inhibition by carbamate derivatives is strongly influenced by the substituent at the $N$-carbamoyl group. Indeed, while short-chain alkyl carbamates, such as those bearing a $\mathrm{H}$ or a methyl residue, give relatively rapid carbamoylation and decarbamoylation (e.g. physostigmine), long-chain alkyl carbamates generally provide a more stable carbamoylated enzyme which is formed slower but also undergoes a slower hydrolysis towards a reactivated enzyme. ${ }^{23,24}$ The kinetics of enzyme inhibition and reactivation influences the duration of action of a carbamate drug. Indeed, the human pharmacodynamic half-life $\left(\mathrm{T}_{1 / 2}\right)$ of $(-)$-eptylstigmine, bearing a hepyl chain at the carbamic nitrogen, is about $10 \mathrm{~h},{ }^{25}$ while that of physostigmine $\left(\mathrm{R}=\mathrm{CH}_{3}\right)$ is about 30 min. ${ }^{26}$

Thus, to assess the influence of the different $\mathrm{R}$ groups on the kinetics of ChEs carbamoylation, studies were carried out on the representative compounds $\mathbf{9}$, bearing a heptyl residue, $\mathbf{1 2}$, with a $p$ hexylphenyl residue and $\mathbf{1 3}$, bearing a phenylhexyl moiety, and data were compared to those previously obtained for $\mathbf{1}$, bearing a phenylpentyl group. The four selected derivatives were characterized by an identical aromatic group ( $2 \mathrm{H}$-chromen-2-one), an identical length of the spacer chain $(n=1)$ and only differed by the $\mathrm{R}$ residue. To exclude an influence of the spacer chain length $(\mathrm{n})$, the inhibition profile of compound $\mathbf{1 5}(\mathrm{n}=3)$ was also evaluated. The time-dependent inhibition of $h \mathrm{AChE}$ by an inhibitor concentration close to its $\mathrm{IC}_{50}$ value was monitored. The obtained profiles are overlaid in Figure 2a. As highlighted in previous studies on 1, the presence of a phenylpentyl moiety determined a rather slow inactivation of $h \mathrm{AChE}$, and a 120 min-incubation period was required to reach the inhibition plateau. ${ }^{17}$ To mention, since $\mathrm{R}$ is the major determinant on the carbamoylation kinetics, similar profiles can be assumed for all derivatives, within this work, bearing a phenylpentyl residue. The introduction of a heptyl chain, as in $\mathbf{9}$, led to a slightly faster AChE inactivation (Figure 2a). Neither the substitution of the phenylpentyl residue with a phenylhexyl one (as in 13) nor the length of the spacer chain $(\mathbf{9}, \mathrm{n}=1$ vs $\mathbf{1 5}, \mathrm{n}=3$ ) significantly modified the kinetics of AChE inactivation (SI, Figure 1S and 2Sa, respectively). Conversely, and quite 
interestingly, the introduction of a $p$-hexylphenyl residue on the $N$-carbamoyl group (compound 12) determined a much faster AChE inactivation and less than 60 min were required to reach the maximum inhibition (Figure 2a).

a)

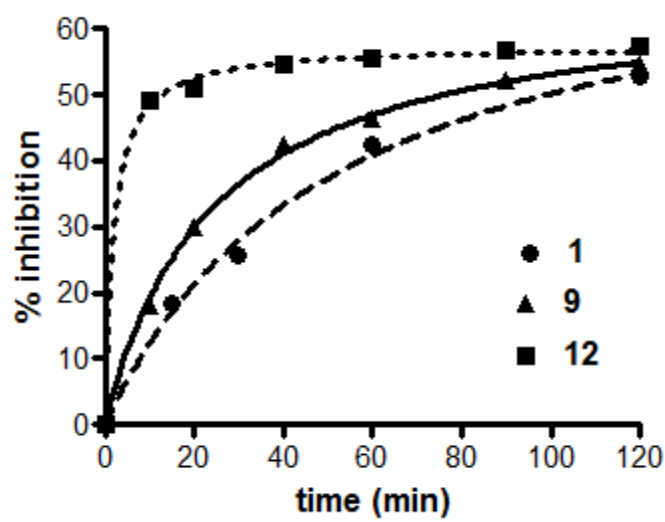

b)

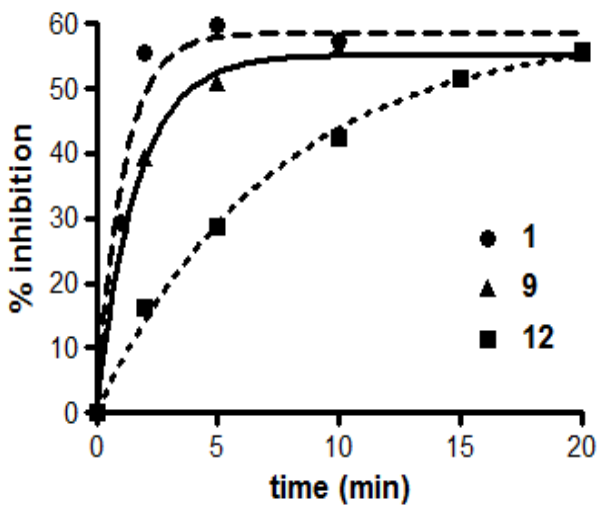

Figure 2. Overlaid carbamoylation profiles of compound 9, 12 and reference compound 1 on a) $h \mathrm{AChE}$ and b) $h \mathrm{BuChE}$.

A similar study was carried out to investigate the kinetics of $h \mathrm{BuChE}$ inhibition. On the basis of the results previously obtained for $\mathbf{1},{ }^{17}$ which was able to inactivate $h \mathrm{BuChE}$ in less than $5 \mathrm{~min}$, the experiments were performed using incubation times ranging from 2 to $20 \mathrm{~min}$. The inhibition profiles obtained for derivatives $9(\mathrm{R}=$ heptyl $), \mathbf{1 2}(\mathrm{R}=\mathrm{p}$-hexylphenyl $)$ and $\mathbf{1}$, as reference, are overlaid in Figure $2 b$.

In opposition to what was observed for $h \mathrm{AChE}$ inactivation, $h \mathrm{BuChE}$ inactivation by 9 was slightly slower, although very rapid (maximum inhibition in $5 \mathrm{~min}$ ), than that observed with $\mathbf{1}$, while inactivation by 12 was significantly slower and the maximum inhibition was reached in 20 min. Finally, similarly to what was observed for AChE, the spacer-chain length did not influence the kinetics of $h \mathrm{BuChE}$ carbamoylation $(\mathbf{9}, \mathrm{n}=1$ vs $\mathbf{1 5}, \mathrm{n}=3$, overlaid profiles in SI, Figure 2Sb) and the $h \mathrm{BuChE}$ inhibition by $\mathbf{1 3}$, bearing a $p$-phenylhexyl residue, closely matched that of $\mathbf{1}$, bearing a phenylpentyl residue. 
Thus, the trend observed for AChE inactivation was $p$-hexylphenyl $>$ heptyl $>$ phenylpentyl $\cong$ phenylhexyl (from faster to slower), while it was phenylpentyl $\cong$ phenylhexyl $>$ heptyl $>p$ hexylphenyl for BuChE. Consequently, because of the opposite trends, the $p$-hexylphenyl derivative 12 inactivated the two ChEs within much closer time-frames (SI, Figure 3S). $\mathrm{k}_{\text {obs }}$ (observed pseudofirst-order inhibition rate constant) values, calculated at concentrations of $\mathbf{1 2}$ close to the $\mathrm{IC}_{50}$ values, were $0.203 \mathrm{~min}^{-1}$ and $0.461 \mathrm{~min}^{-1}$ for $\mathrm{AChE}$ and BuChE inhibition, respectively. The carbamoylation rate constants $\left(\mathrm{k}_{3}\right)$ for $h \mathrm{AChE}$ and $h \mathrm{BuChE}$ inhibition by $\mathbf{9}$, as representative of derivatives bearing an heptyl substituent, were determined. To this aim, different concentrations of 9 were added to the enzyme solution and incubated at $37^{\circ} \mathrm{C}$ for $15-120 \mathrm{~min}$. Data were treated according to Feaster and Quinn method. ${ }^{27}$ Time- and concentration-dependent carbamoylation profiles are shown in Figure 3. The calculated carbamoylation rate constant for AChE inactivation by 9 was $0.238 \pm 0.019 \mathrm{~min}^{-1}$ while it was $11.1 \pm 4.5 \mathrm{~min}^{-1}$ for BuChE inhibition. A comparison with the carbamoylation rate constant obtained for $\mathbf{1}$ confirmed that the presence of the heptyl chain provides a faster inactivation of $h \mathrm{AChE}\left(0.238 \mathrm{~min}^{-1} \mathrm{vs} 0.109 \mathrm{~min}^{-1}\right.$ for $\mathbf{9}$ and $\mathbf{1}$, respectively) and a slower inactivation of $h \mathrm{BuChE}\left(11.1 \mathrm{~min}^{-1} \mathrm{vs} 21.4 \mathrm{~min}^{-1}\right.$ for $\mathbf{9}$ and $\mathbf{1}$, respectively) with respect to the phenylpentyl residue (as in 1). However, kinetics for the inactivation of the two cholinesterases by 9 still differed by an order of magnitude, i.e. 9 carbamoylated $h \mathrm{BChE} 47$ times faster than $h \mathrm{AChE}$. Thus, on the basis of both inhibitory activity and kinetics, 9 will mainly act as a $h \mathrm{BChE}$ inhibitor. This selectivity profile makes this compound potentially more beneficial in moderate forms of $\mathrm{AD}$, in which, because of the progressive reduction of $\mathrm{AChE}$ levels in the cholinergic synapses, $\mathrm{BChE}$ becomes the major actor in the regulation of the central cholinergic tone., 
a)

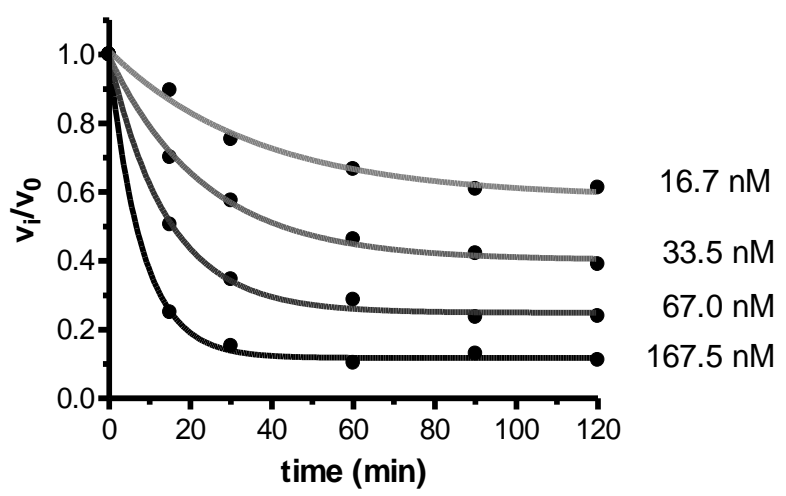

b)

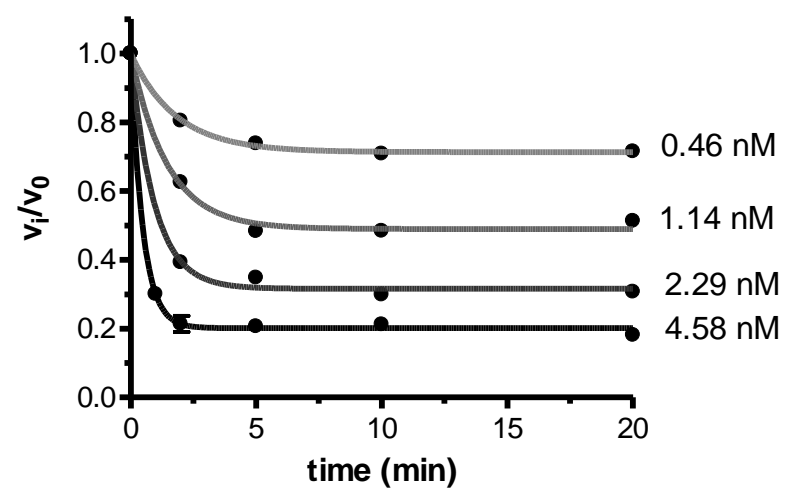

Figure 3. Time- and concentration-dependent carbamoylation of a) $h \mathrm{AChE}$ and b) $h \mathrm{BuChE}$ by compound 9. $\mathrm{v}_{\mathrm{i}}$ and $\mathrm{v}_{0}$ indicate the enzyme activity in the presence and in the absence of inhibitor, respectively.

\section{FAAH inhibition}

The inhibitory potencies of compounds $\mathbf{2 - 1 7}$, expressed as $\mathrm{IC}_{50}$ values, against AEA hydrolysis by FAAH in rat brain membranes are reported in Table 1. All compounds, except for $\mathbf{1 2}$, were able to decrease AEA hydrolysis and, in contrast to what was observed for inhibition of AChE, FAAH seemed to be more susceptible to modifications of the coumarin core. In particular, the introduction of a methyl group in position 4 (compound 2 ) led to a 3-fold decrease in potency with respect to the lead 1, and a drastic drop in potency emerged when a cyclohexane ring was incorporated in the coumarin scaffold (compound 3). When the cyclohexane was replaced by a phenyl ring, activity was partially restored (compound 4), and it was maintained also with the phenylcoumarin core, independently from the presence of a methoxy or chloro $p$-substituent on the phenyl ring (compounds 5-8).

A different behavior was highlighted when the carbamic function was modified: going from the phenylpentyl carbamic function of compound $\mathbf{1}$ to the $N$-heptyl carbamate, an increase in potency was observed. Remarkably, compound $\mathbf{9}$, with the coumarin core, showed, after preincubation, 
activity in the nanomolar range $\left(\mathrm{IC}_{50}=28.55 \mathrm{nM}\right)$ as expected from pseudoirreversible inhibitors, being about twice as potent as the lead compound $\mathbf{1}$. The same trend of potency was noted for compound $\mathbf{1 0}$ when compared to $\mathbf{3}\left(\mathrm{IC}_{50}=306.4 \mathrm{nM}\right.$ vs $\left.1385.4 \mathrm{nM}\right)$. When the phenyl ring was directly bound to the carbamic nitrogen, the inhibitory activity was completely lost (compound $\mathbf{1 2}$, with a hexylphenyl carbamate). This detrimental effect had been previously observed for a series of $\mathrm{O}$-aryl carbamates, ${ }^{28}$ and was attributed to the limited hydrolytic stability of O,Ndiarylcarbamates. ${ }^{29}$ A significant decrease in activity was observed for $\mathbf{1 3}$, bearing only an additional methylene unit, with respect to $\mathbf{1}$.

Regarding the spacer, the elongation of the alkoxy chain from 3- to 5-methylene units allowed to maintain the inhibitory potency in the nanomolar range, still being $\mathbf{1 4}$ twofold less potent than the corresponding lead $\mathbf{1}$.

Finally, the modifications performed on the azaxanthone derivatives (compounds $\mathbf{1 1}$ and 17) did not seem to appreciably affect the activity, unlike what emerged in our previous paper. ${ }^{17}$

\section{FAAH Docking Studies}

Docking studies were performed for the lead compound $\mathbf{1}$ and for other derivatives to explore their possible binding modes to rat FAAH.

The binding site of FAAH (Figure 4) extends from the Acyl Chain Binding (ACB) channel, which receives the substrate from the membrane, to the dimerization interface, which includes the hydrophilic region from which ethanolamine is released after substrate cleavage (cytosolic port). ${ }^{30}$ Just beyond the active site, the cytosolic port divides into a minor branch, which is the putative accommodation pocket of the biphenyl group of the reference inhibitor 66 (URB597), ${ }^{31}$ and a larger cavity, lined by the alcoholic side chain of T236. Compound $\mathbf{1}$, a tertiary amine, could be docked into FAAH binding site either in its protonated-cationic form or in the neutral one. Additional biological assays revealed that $\mathrm{IC}_{50}$ values are affected by $\mathrm{pH}$ conditions (Table 2). Specifically, 66 
showed a 6-fold decrease in potency (increase in $\mathrm{IC}_{50}$ value) when the $\mathrm{pH}$ was lowered from 9 to 7.4. This is consistent with the lower catalytic efficiency of FAAH at lower $\mathrm{pH}$ for both amides ${ }^{32}$ and esters, ${ }^{33}$ which likely reflects a lower carbamoylation rate by the inhibitor. Similarly, concerning the $\mathrm{pH}$-dependence of anandamide hydrolysis by rat brain homogenates, the $\mathrm{IC}_{50}$ values of oleoyltrifluoromethylketone and arachidonoyl serotonin were increased by 7 - and 3 folds, respectively. ${ }^{34}$ Notably, compound $\mathbf{1}$, which is characterized by the same $O$-phenylcarbamic function as 66, showed a significantly higher (22-fold) loss of potency at $\mathrm{pH}$ 7.4. Assuming that the effect of reduced enzyme activity is the same for both compounds, this difference could be attributed to different degrees of protonation of the basic chain of $\mathbf{1}$. This hypothesis, which implies that the tertiary amine of $\mathbf{1}$ binds FAAH in its neutral state, was thus followed throughout this work.

Table 2. Values of $\mathrm{IC}_{50}$ at different $\mathrm{pH}$, with a 10-min preincubation.<smiles>NC(=O)c1cccc(-c2cccc(OC(=O)NC3CCCCC3)c2)c1</smiles>

\begin{tabular}{|ccc|}
\hline Compound & IC50 $(\mathbf{n M})$ & IC50 $(\mathbf{n M})$ \\
& at $\mathbf{p H ~ 9 . 0}$ & at $\mathbf{p H} 7.4$ \\
$\mathbf{n} \geq \mathbf{2}$ & $\mathbf{n} \geq \mathbf{2}$ \\
\hline $\mathbf{6 6}$ & 23.5 & 140.8 \\
$\mathbf{1}$ & 183.1 & 4099.1 \\
\hline
\end{tabular}

Docking studies revealed that compound 1, docked in the neutral form, occupies the binding site almost completely. The carbamate group is placed in close contact with the catalytic serine (S241), and establishes polar interactions with the oxyanion hole residues (I238, G239 and M191). While in all docking poses the N-phenylpentyl chain fits the ACB channel, the O-phenyl group assumes different accommodations within the binding pocket, with different orientations of the 
methylamine linker and of the coumarin scaffold in the cytosolic port. In the first family of docking poses, which includes the top-ranked binding modes, the methylamino group and the coumarin head occupy the upper portion of the cytosolic port major cleft, with the basic nitrogen involved in a hydrogen bond with the hydroxyl group of T236. In the second family, which is less populated and is characterized by lower values of predicted binding affinity, they occupy the minor branch of the cytosolic port, with the coumarin head laying on the lower edge of the major cleft (Figure 4).
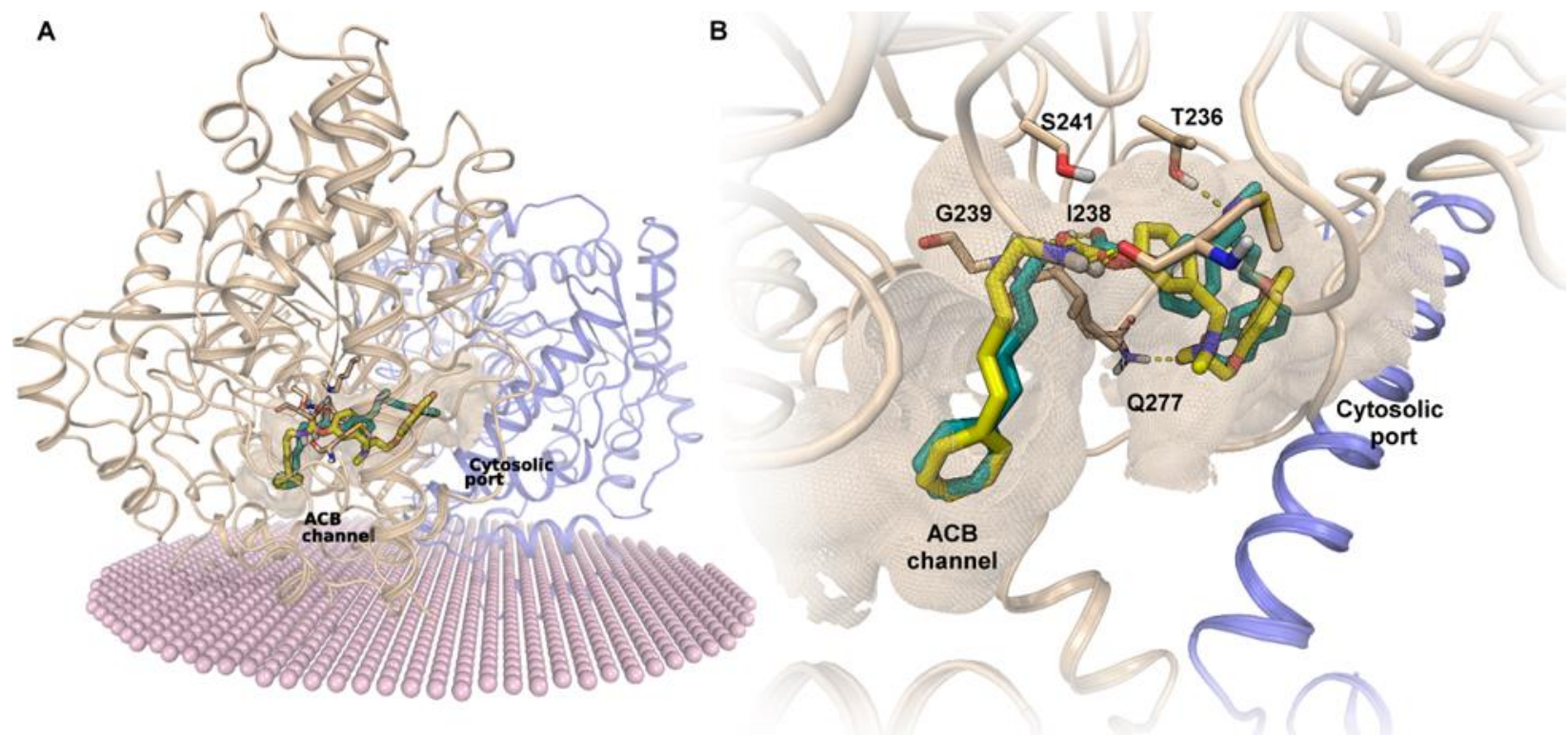

Figure 4. Left panel (A): representation of the FAAH dimer (chain A, light blue ribbons, chain B, wheat ribbons); compound 1, docked in the neutral form occupies the binding site adopting two distinct conformations, clustered in family 1 (green carbons) and family 2 (yellow carbons). Right panel (B): close-up view of the binding modes of compound $\mathbf{1 .}$

The binding mode of the most potent compound 9 in its neutral form to rFAAH (SI, Figure 4S) strictly reproduced the docking solutions illustrated for compound $\mathbf{1}$.

Bulkier derivatives characterized by a five-methylene chain, including compound $\mathbf{1 4}$, tend to adopt the second binding mode, as a consequence of the longer alkyl spacer (Figure 5). 


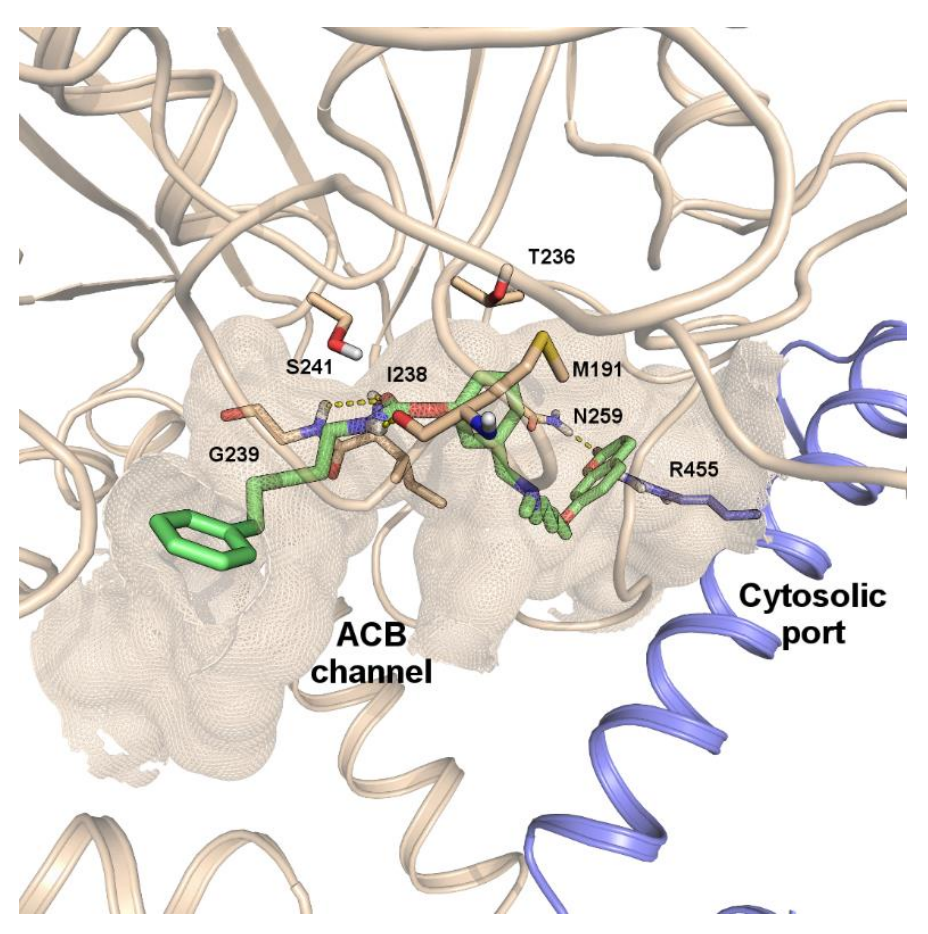

Figure 5. Binding mode of compound 14 docked in its neutral form.

Following the hypothesis that the tertiary amine nitrogen of $\mathbf{1}$ could accept a H-bond by T236, we replaced the amino group with a triazole ring linked to the phenylpentyl- or heptylcarbamate group through a benzyl spacer (compound 18-21), or directly inserted on the phenyl ring (22-25). The inhibitory potencies of compounds $\mathbf{1 8 - 2 5}$ are reported in Table 3.

Table 3. Inhibitory activity of compounds $\mathbf{1 8 - 2 5}$ and reference compound $\mathbf{1}$ against $r$ FAAH, $h \mathrm{AChE}$ and $h \mathrm{BuChE}$.<smiles>[R]NC(=O)Oc1ccccc1Nn1cc(COc2ccc3ccc(=O)oc3c2)nn1</smiles> 


\begin{tabular}{|c|c|c|c|c|c|c|c|}
\hline & \multirow{2}{*}{$\begin{array}{l}\text { Chain } \\
\text { position }\end{array}$} & \multirow[t]{2}{*}{$\mathbf{n}$} & \multirow[t]{2}{*}{$\mathbf{R}$} & \multicolumn{2}{|c|}{$\mathrm{IC}_{50} r \mathrm{FAAH}(\mathrm{nM}) \pm \mathrm{SD}^{a}$} & \multicolumn{2}{|c|}{$\mathrm{IC}_{50}(\mathrm{nM}) \pm \mathrm{SEM}^{b}$} \\
\hline & & & & $\begin{array}{l}\text { std protocol } \\
(n \geq 2)\end{array}$ & $\begin{array}{l}\text { pre-incub prot. } \\
\qquad(\mathrm{n} \geq 2)\end{array}$ & $h \mathrm{AChE}^{c}$ & $h \mathrm{BuChE}^{d}$ \\
\hline 1 & - & - & - & $280^{e}$ & $50^{e}$ & $74.9 \pm 2.0^{e}$ & $1.57 \pm 0.18^{e}$ \\
\hline 18 & para & 1 & & $112.8 \pm 8.6$ & $28.5 \pm 7.9$ & $255 \pm 12$ & $1.17 \pm 0.12$ \\
\hline 19 & meta & 1 & & $157.2 \pm 10.5$ & $27.9 \pm 6.6$ & $922 \pm 89$ & $42.7 \pm 1.5$ \\
\hline 20 & para & 1 & & $353.6 \pm 35.3$ & $55.0 \pm 11.2$ & $214 \pm 19$ & $15.9 \pm 0.5$ \\
\hline 21 & meta & 1 & & $108.6 \pm 67.6$ & $32.6 \pm 8.2$ & $1044 \pm 82$ & $78.2 \pm 4.8$ \\
\hline 22 & para & 0 & & $236.2 \pm 24.3$ & $43.3 \pm 3.0$ & $47900 \pm 1400$ & $1230 \pm 90$ \\
\hline 23 & meta & 0 & & $208.7 \pm 0.3$ & $44.7 \pm 6.1$ & $1175 \pm 145$ & $15.2 \pm 1.2$ \\
\hline
\end{tabular}




$$
\text { meta }
$$

0

$61.9 \pm 26.9$

$15.7 \pm 1.7$

$702 \pm 18$

$71.2 \pm 2.9$

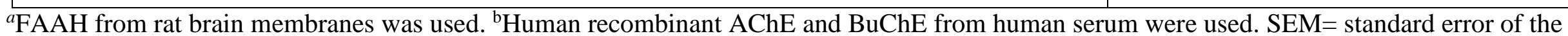
mean. ${ }^{c} \mathrm{IC}_{50}$ values were determined using a 120 min-incubation time; ${ }^{d} \mathrm{IC}_{50}$ values for phenylpentyl derivatives were determined using a 15 -min incubation time, while $\mathrm{IC}_{50}$ values of the heptyl derivatives were determined using a 20-min incubation time. ${ }^{e}$ Data from reference. ${ }^{17}$ 
From a first glance at the results, all the tested compounds of the second series $(\mathbf{1 8 - 2 5})$ turned out to successfully inhibit $\mathrm{FAAH}$, with $\mathrm{IC}_{50}$ values within a close range (from 15.7 to $55.0 \mathrm{nM}$ ), thus confirming the design hypothesis. It should be noted that, unlike what previously reported (2-17), the increase in rigidity of the linker seemed to be the major feature affecting activity. Indeed, compounds 18-25 all showed a comparable potency, regardless of the nature and the insertion position of the carbamate. Remarkably, almost all derivatives in this new series proved to be more potent than the lead compound $\mathbf{1}$, and $\mathbf{2 5}$, with a triazole ring directly connected to the phenyl ring, emerged as the most potent compound.

Docking studies performed for compounds 18-25 revealed the existence of alternative binding modes, comparable to those obtained for derivatives 1-17, depending on the position of the carbamate group and on the flexibility of the triazole-containing linker. Compounds $\mathbf{1 8}$ and $\mathbf{1 9}$, characterized by a flexible linker, assumed binding modes similar to that of the second family for compound 1 (Figure 6).
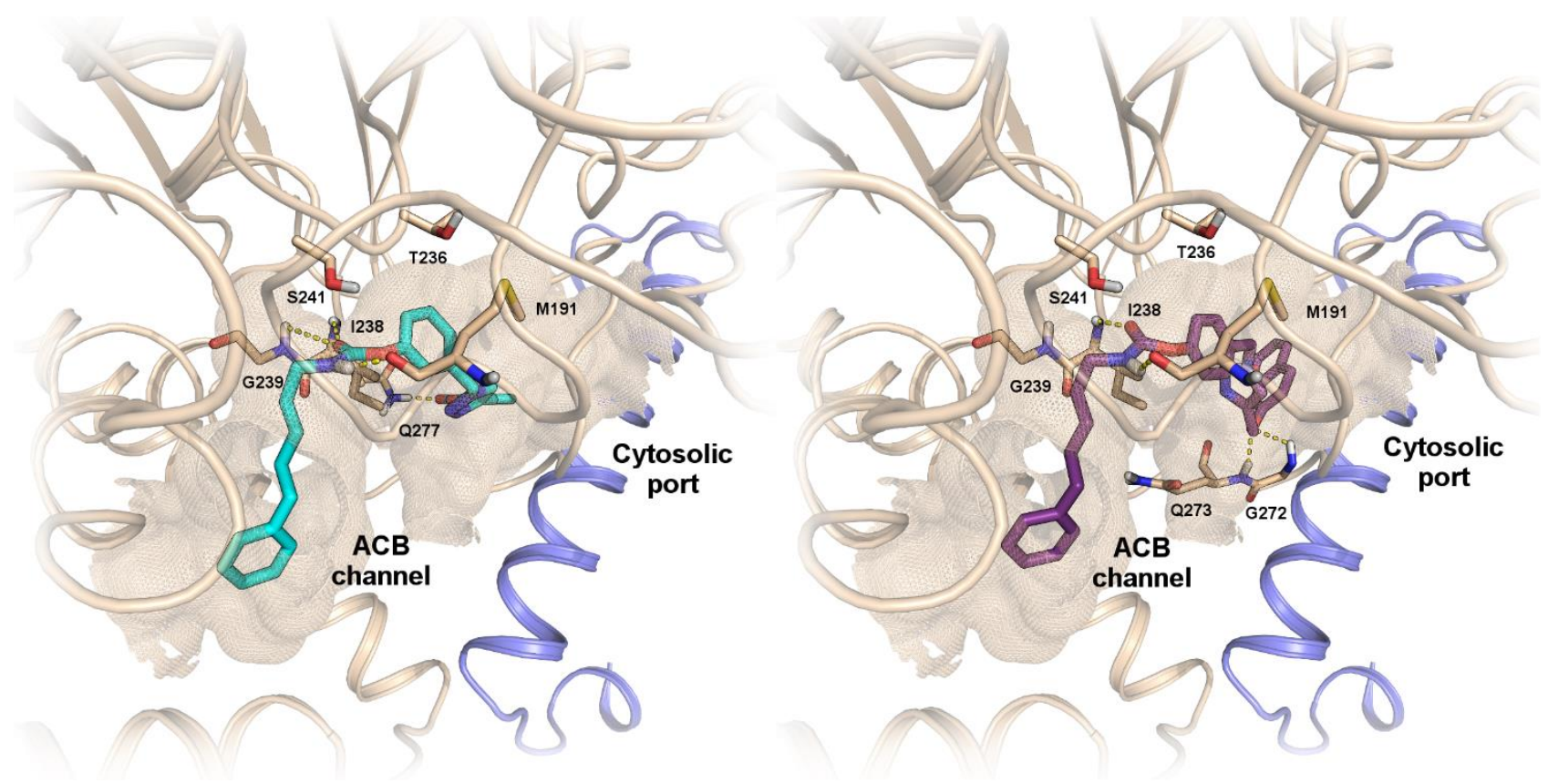
Figure 6. Details of the binding mode of compounds 18 (left panel, cyan carbons) and 19 (right panel, purple carbons)

The reduced flexibility of the linker in compounds $\mathbf{2 2}$ and $\mathbf{2 3}$, due to the direct insertion of the triazole ring on the phenylcarbamate group, led to solutions similar to the binding modes of compound 1 family 1 (Figure 7).
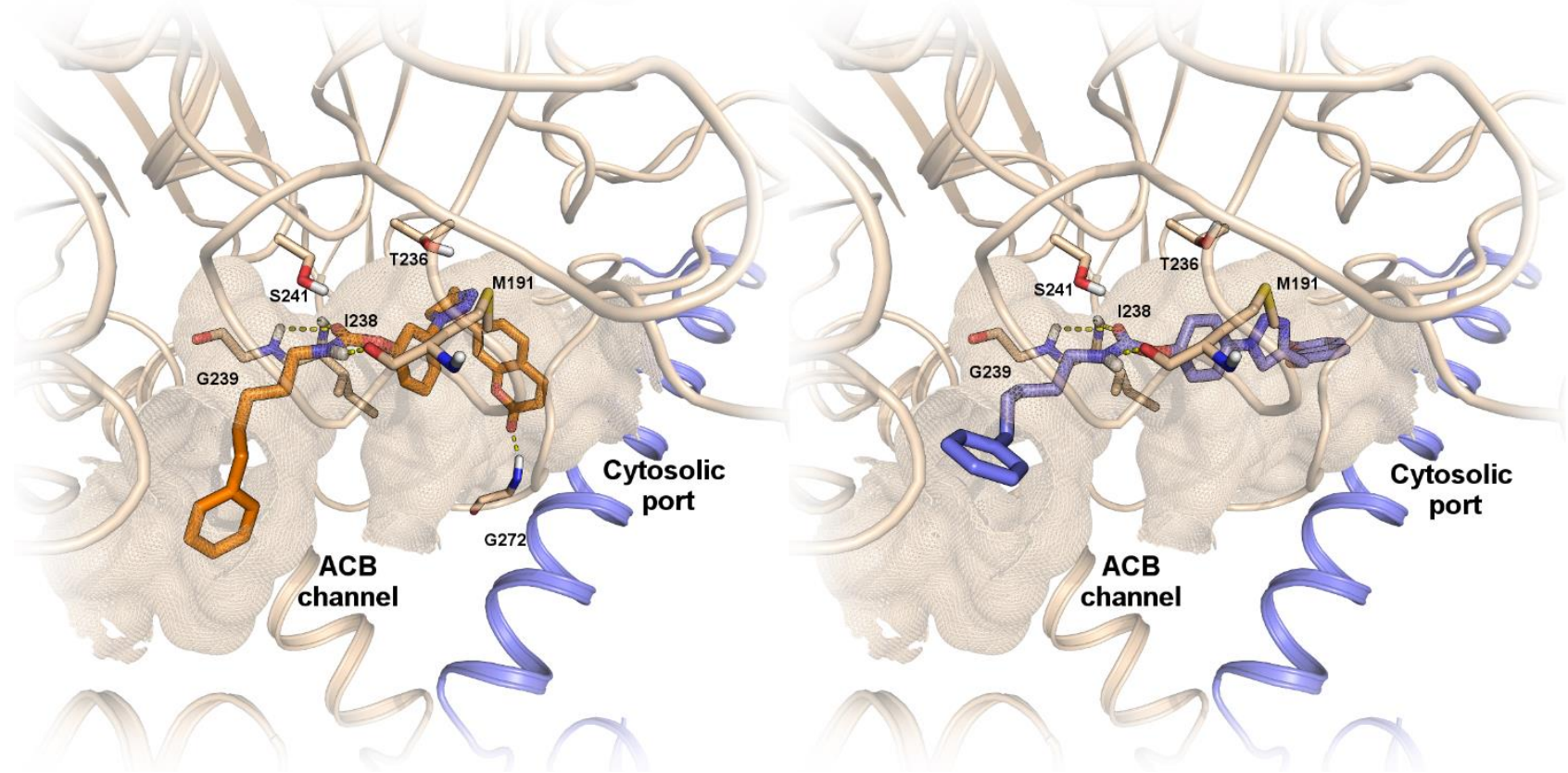

Figure 7. Details of the binding modes of compounds 23 (left panel, orange carbons) and 22 (right panel, light blue carbons)

\section{Cholinesterase inhibition by compounds 18-25 and BuChE Docking Studies}

The new series was also tested on human ChEs using the method of Ellman. ${ }^{19}$ Biological data, reported in Table 3, showed a significant loss of potency against $h \mathrm{AChE}$, probably due to the rigidity of the inhibitor structures, which may hamper a proper accommodation into the enzyme's narrow gorge. A general, although less marked, reduction of inhibitory potency against $h \mathrm{BuChE}$ compared to 1 was also found, with $\mathrm{IC}_{50}$ values still in the nanomolar range, except for $\mathbf{2 2}$ and $\mathbf{2 4}$. Indeed, a comparison of $h \mathrm{BuChE}$ and $h \mathrm{AChE}$ gorges shows differences in size, especially in the 
acyl chain-binding pockets. In $h \mathrm{BuChE}$ the active site gorge is $\operatorname{larger}^{35}$ than in $h \mathrm{AChE}$, due to the presence of a valine and a leucine instead of the bulkier phenylalanines of $h \mathrm{AChE}$, enabling larger molecules to better fit into the gorge. Compounds 18, 20 and 23 proved to be the most potent $h \mathrm{BuChE}$ inhibitors in this second series.

Docking studies were performed to investigate the possible binding mode of the triazole-based derivatives within $h \mathrm{BuChE}$ active site (PDB ID: 4TPK).$^{36}$ Compound $\mathbf{1}$ gave a binding pose consistent with enzyme inhibition by carbamoylation of the catalytic serine and in line with the accommodation reported for similar compounds in both AChE and BuChE. ${ }^{37,38}$ In particular, compound 1 was deeply inserted within the active-site gorge, assuming a folded conformation, with the carbamate group directed toward the catalytic triad (S198, H438 and E325), while the coumarin head and the acyl chain pointed toward the entrance of the gorge (Figure 8A). The carbamate carbonyl was accommodated close to the catalytic serine (S198, Figure 8B), taking polar interactions with the oxyanion hole residues (G116 and G117). At the bottom of the binding site, the phenyl ring attached to the carbamate group pointed toward the choline-binding pocket, occluded by W82. This pose was stabilized by a hydrogen bond between the protonated amino group and the side chain of T120. The coumarin head occupied the wide access channel of the active-site gorge, pointing toward the peripheral anionic site (PAS). Here the bicyclic nucleus could assume different positions in alternative docking solutions: in the pose represented in Figure 8B it establishes a polar interaction with the side chain of Q289. The protein surface at the entrance of the gorge is quite flat and hydrophobic. This could be the reason of the good potency of compounds with tricyclic nuclei, such as $\mathbf{1 0}$ (see SI, Figure 5S), 11, 16 and 17. The phenylpentyl chain at the carbamate nitrogen was accommodated within the putative acyl chain-binding pocket, which is lined by L286 and V288 in $h$ BuChE. Notably, in $h$ AChE these residues are replaced by F295 and F297, which reduce the pocket size, hampering the accommodation of bulky lipophilic groups. Thus, also considering the reduced potency of compounds $\mathbf{1 8 - 2 5}$ as $h \mathrm{AChE}$ inhibitors, we decided not to perform docking studies into hAChE models, to avoid overinterpretation of structure-activty 
relationships. Indeed, the different size of the acyl chain-binding pockets is sufficient to explain the selectivity for $h \mathrm{BuChE}$ (approximately 50 fold) of compound $\mathbf{1}$ and its derivatives, while the $N$ methyl analog xanthostigmine is 160 -fold more potent at $h \mathrm{AChE}$ than at $h \mathrm{BuChE} .{ }^{37}$
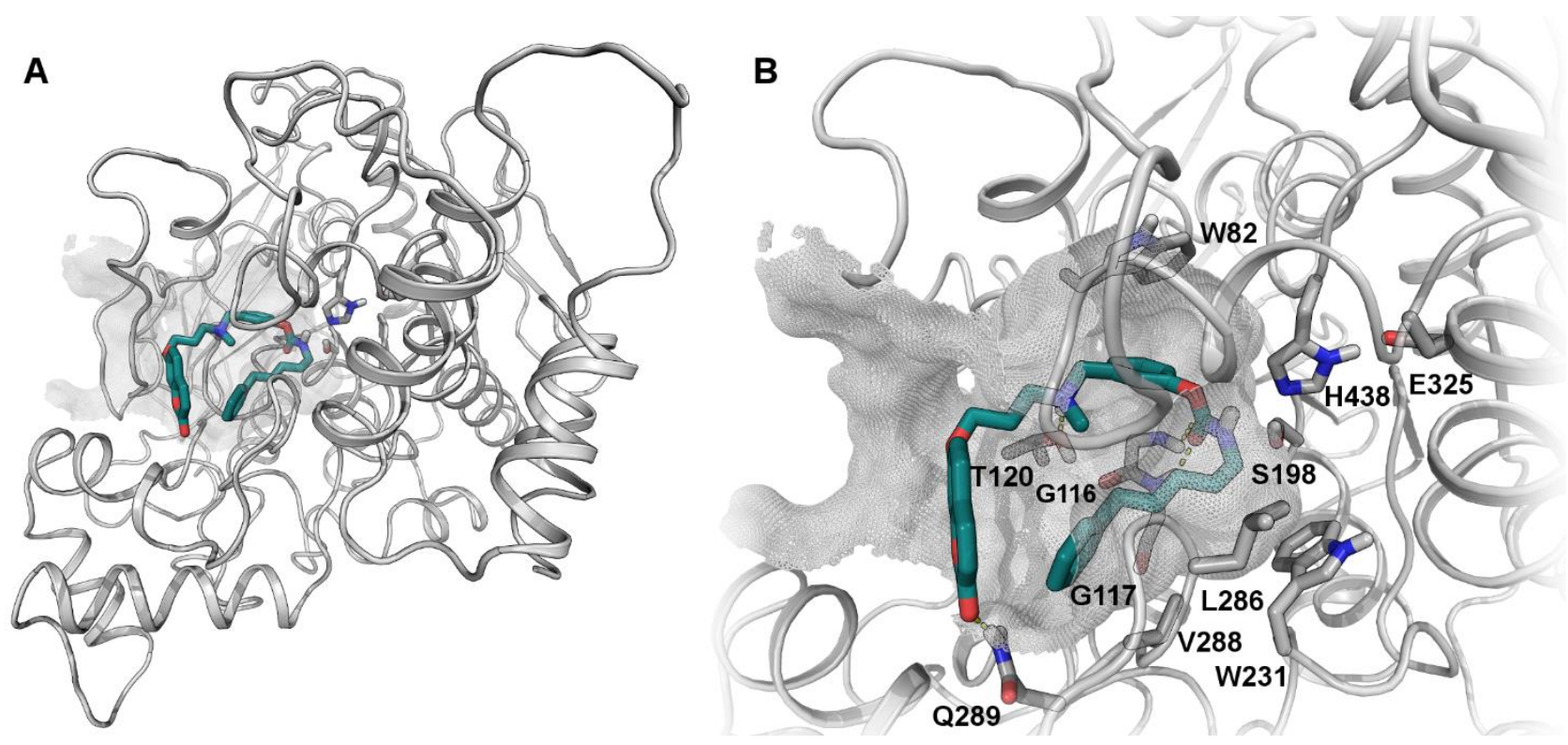

Figure 8. A. Docking of compound 1 (green carbons) within the catalytic gorge of $h \mathrm{BuChE}$. B. Detailed picture of the binding mode of compound 1. Hydrogen bonds are marked with yellow dotted-lines.

Docking studies for triazole derivatives provided similar binding modes, and substitution at the phenyl ring carrying the carbamate group proved to be crucial for structure-activity relationships. While the para-methylene spacer of $\mathbf{1 8}$ allowed the triazole ring to accept a hydrogen bond from the hydroxyl group of T120, the meta-methylene spacer of $\mathbf{1 9}$ allowed the compound to occupy the $h \mathrm{BuChE}$ gorge, but not to take polar interactions with T120 (Figure 9A). On the other hand, when the triazole was directly attached to the phenyl ring (compound 22), no docking poses consistent with carbamoylation of S198 were obtained for the para isomer, due to a steric clash between W82 and the triazole ring, while meta substitution (compound $\mathbf{2 3}$ ) allowed the coumarin head to be 
accommodated at the entrance of the gorge (Figure 9B). These docking poses are consistent with the potency rank order: $18>\mathbf{2 3} \approx \mathbf{1 9}>\mathbf{2 2}$ which was observed for phenylpentyl derivatives and, for corresponding compounds, also for heptyl ones.
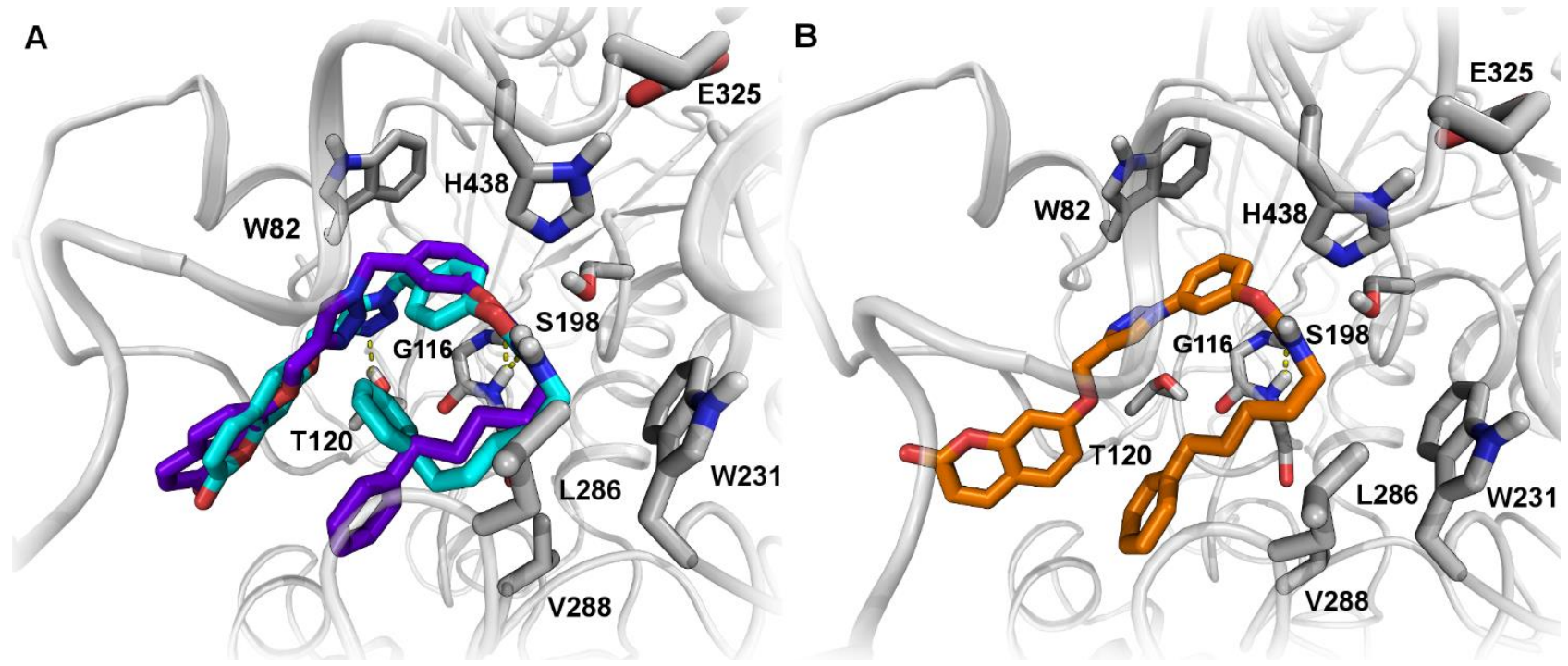

Figure 9. A. Docking of compounds 18 (cyan carbons) and 19 (purple carbons) within the catalytic gorge of $h \mathrm{BuChE}$. B. Binding mode of compound $\mathbf{2 3}$ (orange carbons) within $h \mathrm{BuChE}$. Hydrogen bonds are marked with yellow dotted-lines.

\section{Structure-activity relationship highlights and dual ChE/FAAH inhibition}

Well-balanced activity on different validated targets is an essential requirement for a multi-target drug candidate. Biological results and docking studies clearly show that the basic nitrogen of compound $\mathbf{1}$ is not essential for FAAH inibition. In fact, it can be replaced by a neutral heterocycle, which can be attached to the O-phenyl carbamante at either meta or para position, with or without a methylene spacer, due to the multiple accommodations possible at FAAH binding pocket. These compounds displayed greater potencies at $h \mathrm{BuChE}$ than at $h \mathrm{AChE}$, probably due to the size of the lipophilic chain at the carbamate nitrogen. For $h \mathrm{BuChE}$ inhibition, the tertiary amino group of 
compounds 1-17 provides high potency, allowing different lipophilic chains and terminal coumarin or coumarin-like scaffolds. It can again be replaced by a neutral heterocyle, but its accommodation within the bottom of the enzyme gorge requires specific combinations of substitution at phenyl ring and spacer length. Future developments of dual ChE/FAAH inhibitors with an N-alkyl-Ophenylcarbamate scaffold can be accomplished without a basic functionality, which can be replaced by five-membered neutral heterocycles with the above-mentioned structural requirements. Docking studies and biological data available so far suggest that the most promising series would allow different lipophilic chains and terminal coumarin scaffolds.

It is noteworthy that some compounds presented in this study proved to be very potent inhibitors of a single selected target, while lacking dual activity, and this clearly reflects the different tridimensional structures of cholinesterases and FAAH and the corresponding dissimilar structural requirements for their inhibition. Nevertheless, within the reported first series of compounds, 9 showed an increased potency against all the three selected targets when compared with the lead compound 1, and was endowed with a balanced inhibition of $\mathrm{AChE}$ and FAAH $\left(\mathrm{IC}_{50}=37.4 \mathrm{nM}\right.$ and $28.5 \mathrm{nM}$, respectively). Remarkably, within the second series, compound 19 showed an increased inhibitory activity towards FAAH, and was endowed with a well-adjusted nanomolar inhibitory activity on both BuChE and FAAH ( $\mathrm{IC}_{50}=42.7 \mathrm{nM}$ and $27.9 \mathrm{nM}$, respectively).

\section{Cytotoxicity}

We investigated the effects of the lead compound $\mathbf{1}$ and derivatives $\mathbf{9}$ and $\mathbf{2 5}$, with respect to reference 66, on human neuronal SH-SY5Y cell viability in vitro by means of the colorimetric MTT metabolic activity assay. ${ }^{39}$ Cytotoxicity was determined by incubating neuronal SHSY-5Y cells for $24 \mathrm{~h}$ with increasing concentrations $(1-50 \mu \mathrm{M})$ of the selected compounds followed by an additional incubation of $3 \mathrm{~h}$ with a MTT solution as described in the experimental section. The ability of cells to reduce MTT provides an indication of the mitochondrial integrity and activity, which, in turn, can 
be intended as a measure of cell viability. A threshold of $25 \%$ cell viability was arbitrarily assigned to discriminate the severity of the observed cytotoxic effect. As shown in Figure 10, the treatment of SH-SY5Y cells with the selected compounds did not decrease neuronal cell viability. Indeed, compound 9 showed a cytotoxic effect only at the highest tested concentration $(50 \mu \mathrm{M})$. Taken together, these data suggest a good therapeutic window for all these compounds.

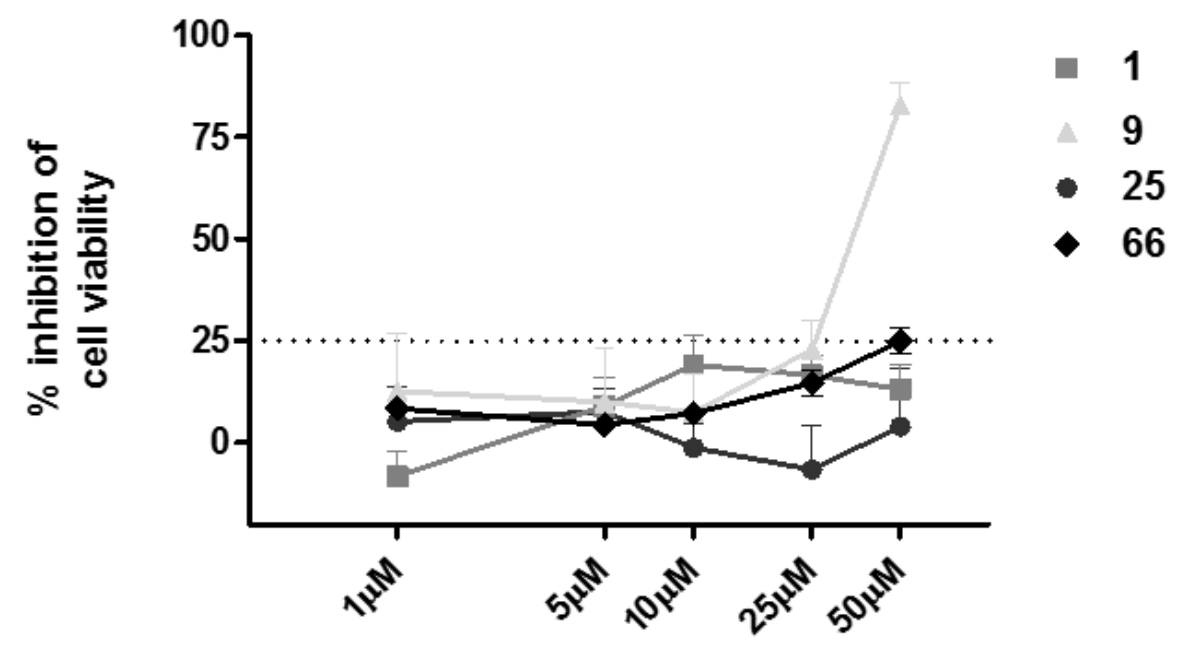

Figure 10. Effect of compounds 1, 9, 25 and reference compound 66 on human neuronal SHSY-5Y cell viability.

\section{Conclusions}

In this paper, appropriate modifications of the previously reported lead compound $\mathbf{1}$ were performed in order to find more potent and balanced dual inhibitors of ChEs and FAAH for AD treatment. All new compounds are carbamates that play an important role in modern medicinal chemistry, due to their chemical stability and capability to increase permeability across cellular membranes, even if they can bind to other targets. ${ }^{40}$ 
Some compounds proved to be extremely potent on a single target. In particular $\mathbf{1 7}$ was found to be a low nanomolar AChE inhibitor, while 10-11 and 15-17 showed sub-nanomolar inhibitory potency towards BuChE, being among the most potent inhibitors currently known for this enzyme. In regards FAAH inhibition, the most interesting compound was $\mathbf{2 5}$, with an $\mathrm{IC}_{50}$ value of $15 \mathrm{nM}$. Notwithstanding the fact that ChEs and FAAH greatly differ in both tridimensional structure and binding site topologies, 9 showed an improved inhibitory activity on all three selected targets while 19 were identified as dual inhibitor, with nanomolar and well-balanced activities on BuChE/FAAH. Hence, considering that $\mathrm{ChE}$ levels vary during disease progression with important implications in the selection of $\mathrm{AChE}$ or $\mathrm{BuChE}$ as main target for treatment, ${ }^{7,8} \mathbf{1 9}$ could represent a promising candidate for the treatment of moderate forms of AD.

Finally, as a general outcome, this paper also expands the knowledge on dual FAAH/ChE inhibitors, giving important insight on the structure-activity relationships for dual activity, which could be used in the future for further developments.

\section{Experimental section}

Chemistry. General Methods. Melting points were measured in glass capillary tubes on a Büchi SMP-20 apparatus and are uncorrected. Direct infusion ES-MS spectra were recorded on a Waters Micromass ZQ 4000 apparatus. ${ }^{1} \mathrm{H}$ NMR and ${ }^{13} \mathrm{C}$ NMR experiments were recorded in $\mathrm{CDCl}_{3}$, unless differently indicated, on Varian VXR $400 \mathrm{MHz}$ instrument. Chemical shifts are reported in parts per million (ppm) relative to tetramethylsilane (TMS), and spin multiplicities are given as s (singlet), $d$ (doublet), t (triplet), m (multiplet) or br (broad). Chromatographic separations were performed on silica gel columns (Kieselgel 40, 0.040-0.063 mm; Merck) by flash chromatography. Chemical purities of the tested compounds were determined by HPLC-MS and confirmed $\geq 95 \%$ purity. (HPLC-MS: Agilent Technologies HP1100 instrument, equipped with a ZOBRAX-Eclipse XDB-C8 
Agilent Technologies column, mobile phase: $\mathrm{H}_{2} \mathrm{O} / \mathrm{CH}_{3} \mathrm{CN}, 0.4 \mathrm{~mL} / \mathrm{min}$, gradient from 30 to $80 \%$ of $\mathrm{CH}_{3} \mathrm{CN}$ in 8 min. $80 \%$ of $\mathrm{CH}_{3} \mathrm{CN}$ until 25min, coupled with an Agilent Technologies MSD1100 single-quadrupole mass spectrometer: full scan mode from $m / z=50$ to 2600 , scan time $0.1 \mathrm{~s}$ in positive ion mode, ESI spray voltage $4500 \mathrm{~V}$, nitrogen gas $35 \mathrm{psi}$, drying gas flow $11.5 \mathrm{~mL} / \mathrm{min}$, fragmentor voltage $20 \mathrm{~V})$. Compounds were named relying on the naming algorithm developed by CambridgeSoft Corporation and used in ChemDraw Professional 15.0.

General method for the preparation of carbamates (2-25). A mixture of the selected $[N$-methyl$N$-(3-hydroxybenzyl]aminoalkoxy derivative $(1.0 \mathrm{mmol})$, the selected isocyanate $(1.0 \mathrm{mmol})$ and $\mathrm{NaH}(10 \mathrm{mg})$ in dry toluene was stirred at rt for $24 \mathrm{~h}$, quenched with water and then extracted with dichloromethane. The organic layer was washed with water, dried and evaporated under reduced pressure. The residue was purified by flash column chromatography (toluene/acetone 4:1).

\section{3-((Methyl(3-((4-methyl-2-oxo-2H-chromen-7-yl)oxy)propyl)amino)methyl)phenyl (5-}

phenylpentyl)carbamate (2). Using the previous procedure and starting from $\mathbf{5 0}$ and 5isocyanatopentylbenzene, ${ }^{17} 2$ was obtained. Yield $43 \%$, mp 81-82 ${ }^{\circ} \mathrm{C} .{ }^{1} \mathrm{H}$ NMR $\delta$ 77.45-7.05 (d, $J$ $=9.2 \mathrm{~Hz} 1 \mathrm{H}, \mathrm{Ar}), 7.43-7.25(\mathrm{~m}, 8 \mathrm{H}, \mathrm{Ar}), 6.95(\mathrm{~d}, J=8 \mathrm{~Hz}, 1 \mathrm{H}, \mathrm{Ar}), 6.90-6.70(\mathrm{~m}, 2 \mathrm{H}, \mathrm{Ar}), 6.12(\mathrm{~s}$, 1H, Ar), 5.35 (br, 1H, NH), 4.05 (t, $\left.J=13.2 \mathrm{~Hz}, 2 \mathrm{H}, \mathrm{OCH}_{2}\right), 3.50\left(\mathrm{~s}, 2 \mathrm{H}, \mathrm{NCH}_{2}-\mathrm{Ph}\right), 3.38-3.20(\mathrm{~m}$, 2H, $\mathrm{CH}_{2}-\mathrm{Ph}$ ), 2.70-2.45 (m, 4H, $\left.\mathrm{NCH}_{2}, \mathrm{CH}_{2}\right), 2.38\left(\mathrm{~s}, 3 \mathrm{H}, \mathrm{CH}_{3}\right), 2.25\left(\mathrm{~s}, 3 \mathrm{H}, \mathrm{NCH}_{3}\right), 2.05-1.85(\mathrm{~m}$, $\left.2 \mathrm{H}, \mathrm{CH}_{2}\right), 1.73-1.52\left(\mathrm{~m}, 4 \mathrm{H}, 2 \mathrm{CH}_{2}\right), 1.51-1.30\left(\mathrm{~m}, 2 \mathrm{H}, \mathrm{CH}_{2}\right) ;{ }^{13} \mathrm{C} \mathrm{NMR} \delta 162.26,161.49,155.29$, $152.72,151.22,142.43,141.52,137.98,128.89,128.66,128.36,128.25,126.33,125.35,121.96$, $120.33,113.32,112.98,111.67,101.22,66.89,62.12,53.03,42.44,40.52,35.77,31.04,29.69$, 26.35, 23.91, 18.65. ES-MS m/z: $543\left(\mathrm{M}+\mathrm{H}^{+}\right), 565(\mathrm{M}+\mathrm{Na})$; HRMS calcd for $\mathrm{C}_{33} \mathrm{H}_{38} \mathrm{~N}_{2} \mathrm{O}_{5}$ 542.2781, found 542.2789.

\section{3-((Methyl(3-((6-oxo-7,8,9,10-tetrahydro-6H-benzo[c]chromen-3-}

yl)oxy)propyl)amino)methyl)phenyl (5-phenylpentyl)carbamate (3). Using the previous procedure and starting from $\mathbf{5 1}$ and 5-isocyanatopentylbenzene, ${ }^{17} \mathbf{3}$ was obtained. Yield $68 \%$, mp 82-83 ${ }^{\circ} \mathrm{C} .{ }^{1} \mathrm{H}$ NMR $\delta 7.43(\mathrm{~d}, J=8.8 \mathrm{~Hz}, 1 \mathrm{H}, \mathrm{Ar}), 7.28-7.22(\mathrm{~m}, 3 \mathrm{H}, \mathrm{Ar}), 7.18-7.13$ (m, 4H, Ar), 
$7.10(\mathrm{~d}, J=7.2 \mathrm{~Hz}, 1 \mathrm{H}, \mathrm{Ar}), 6.99$ (d, $J=8.0 \mathrm{~Hz}, 2 \mathrm{H}, \mathrm{Ar}), 6.81-6.79$ (m, 2H, Ar), 5.30 (br, 1H, NH), $4.30\left(\mathrm{t}, J=12.8 \mathrm{~Hz}, 2 \mathrm{H}, \mathrm{OCH}_{2}\right), 3.50\left(\mathrm{~s}, 2 \mathrm{H}, \mathrm{OCH}_{2}-\mathrm{Ph}\right), 3.28\left(\mathrm{~d}, \mathrm{~J}=6.8 \mathrm{~Hz}, 2 \mathrm{H}, \mathrm{NCH}_{2}\right), 2.76-2.73$ (m, $\left.2 \mathrm{H}, \mathrm{CH}_{2}\right), 2.63-2.50\left(\mathrm{~m}, 6 \mathrm{H}, 3 \mathrm{CH}_{2}\right), 2.25\left(\mathrm{~s}, 3 \mathrm{H}, \mathrm{NCH}_{3}\right), 1.96\left(\mathrm{t}, \mathrm{J}=12.8 \mathrm{~Hz}, 2 \mathrm{H}, \mathrm{CH}_{2}\right), 1.85-$ $1.79\left(\mathrm{~m}, 4 \mathrm{H}, 2 \mathrm{CH}_{2}\right), 1.68-1.61\left(\mathrm{~m}, 4 \mathrm{H}, 2 \mathrm{CH}_{2}\right), 1.43-1.38\left(\mathrm{~m}, 2 \mathrm{H}, \mathrm{CH}_{2}\right) ;{ }^{13} \mathrm{C} \mathrm{NMR} \delta 162.26$, $161.49,155.29,152.72,151.22,142.43,141.52,137.98,128.89,128.66,128.36,128.25,126.33$, $125.35,121.96,120.33,119.59,113.32,112.98,101.22,67.17,63.93,55.78,43.22,41.65,36.78$, 29.87, 29.51, 27.26, 27.23, 26.54, 24.65, 24.40, 24.27. ES-MS $m / z: 583\left(\mathrm{M}+\mathrm{H}^{+}\right), 605(\mathrm{M}+\mathrm{Na})$. HRMS calcd for $\mathrm{C}_{36} \mathrm{H}_{42} \mathrm{~N}_{2} \mathrm{O}_{5} 582.3094$, found 582.3089.

3-((Methyl(3-((6-oxo-6H-benzo[c]chromen-3-yl)oxy)propyl)amino)methyl)phenyl (5phenylpentyl)carbamate (4). Using the previous procedure and starting from 52 and 5isocyanatopentylbenzene, ${ }^{17} 4$ was obtained. Yield $27 \%$, mp 79-80 ${ }^{\circ} \mathrm{C} .{ }^{1} \mathrm{H}$ NMR $\delta 8.37(\mathrm{~d}, J=8.0$ $\mathrm{Hz}, 1 \mathrm{H}, \mathrm{Ar}), 8.02$ (d, $J=8.4 \mathrm{~Hz}, 1 \mathrm{H}, \mathrm{Ar}), 7.93(\mathrm{~d}, J=8.8 \mathrm{~Hz}, 1 \mathrm{H}, \mathrm{Ar}), 7.78$ (t, $J=15.2 \mathrm{~Hz}, 1 \mathrm{H}, \mathrm{Ar})$, $7.50(\mathrm{t}, J=15.2 \mathrm{~Hz}, 1 \mathrm{H}, \mathrm{Ar}), 7.28-7.23(\mathrm{~m}, 4 \mathrm{H}, \mathrm{Ar}), 7.18-7.15(\mathrm{~m}, 3 \mathrm{H}, \mathrm{Ar}), 7.11(\mathrm{~d}, J=7.6 \mathrm{~Hz}, 1 \mathrm{H}$, Ar), $6.99(\mathrm{~d}, J=7.6 \mathrm{~Hz}, 1 \mathrm{H}, \mathrm{Ar}), 6.89(\mathrm{~d}, J=8.8 \mathrm{~Hz}, 2 \mathrm{H}, \mathrm{Ar}), 5.21(\mathrm{br}, 1 \mathrm{H}, N H), 4.07$ (t, $J=12.8$ $\left.\mathrm{Hz}, 2 \mathrm{H}, \mathrm{OCH}_{2}\right), 3.51\left(\mathrm{~s}, 2 \mathrm{H}, \mathrm{NCH}_{2}-\mathrm{Ph}\right), 3.26-3.24\left(\mathrm{~m}, 2 \mathrm{H}, \mathrm{NCH}_{2}\right), 2.61\left(\mathrm{t}, \mathrm{J}=15.2 \mathrm{~Hz}, 2 \mathrm{H}, \mathrm{NCH}_{2}\right)$, $2.53\left(\mathrm{t}, \mathrm{J}=13.2 \mathrm{~Hz}, 2 \mathrm{H}, \mathrm{CH}_{2}-\mathrm{Ph}\right), 2.27\left(\mathrm{~s}, 3 \mathrm{H}, \mathrm{NCH}_{3}\right), 1.67-1.58\left(\mathrm{~m}, 4 \mathrm{H}, 2 \mathrm{CH}_{2}\right), 1.41-1.37(\mathrm{~m}, 2 \mathrm{H}$, $\left.\mathrm{CH}_{2}\right) ;{ }^{13} \mathrm{C}$ NMR $\delta 163.49,158.20,152.56,151.20,142.43,136.54,135.31,134.86,130.51,128.91$, $128.36,128.25,127.62,126.33,125.67,124.38,123.63,121.95,121.05,120.30,119.88,113.11$, $110.87,102.06,66.72,62.11,53.13,41.18,40.50,35.78,31.06,30.08,29.67,26.44$. ES-MS m/z: $579\left(\mathrm{M}+\mathrm{H}^{+}\right), 601(\mathrm{M}+\mathrm{Na})$. HRMS calcd for $\mathrm{C}_{36} \mathrm{H}_{38} \mathrm{~N}_{2} \mathrm{O}_{5}$ 578.2781, found 578.2785.

\section{3-((Methyl-(3-((2-oxo-3-phenyl-2H-chromen-7-yl)oxy)propyl)amino)methyl)phenyl (5-}

phenylpentyl)carbamate (5). Using the previous procedure and starting from 53 and 5isocyanatopentylbenzene, ${ }^{17} 5$ was obtained. Yield $27 \%$, oil. ${ }^{1} \mathrm{H}$ NMR $\delta 7.76$ (s, 1H, Ar), 7.69 (d, J $=7.1 \mathrm{~Hz}, 2 \mathrm{H}, \mathrm{Ar}), 7.47-7.35(\mathrm{~m}, 4 \mathrm{H}, \mathrm{Ar}), 7.30-7.22(\mathrm{~m}, 3 \mathrm{H}, \mathrm{Ar}), 7.17$ (t, J= 7.4 Hz, 4H, Ar), 7.09 (d, $J=7.3 \mathrm{~Hz}, 1 \mathrm{H}, \mathrm{Ar}), 6.99(\mathrm{~d}, J=7.4 \mathrm{~Hz}, 1 \mathrm{H}, \mathrm{Ar}), 6.83(\mathrm{~m}, 2 \mathrm{H}, \mathrm{Ar}), 5.24(\mathrm{br}, 1 \mathrm{H}, N H), 4.06(\mathrm{t}, J$ $\left.=6.5 \mathrm{~Hz}, 2 \mathrm{H}, \mathrm{OCH}_{2}\right), 3.51\left(\mathrm{~s}, 2 \mathrm{H}, \mathrm{NCH}_{2}-\mathrm{Ph}\right), 3.26-3.21\left(\mathrm{~m}, 2 \mathrm{H}, \mathrm{CH}_{2}-\mathrm{Ph}\right), 2.66-2.58(\mathrm{~m}, 2 \mathrm{H}$, 
$\left.N \mathrm{NH}_{2}\right), 2.52\left(\mathrm{t}, \mathrm{J}=6.5 \mathrm{~Hz}, 2 \mathrm{H}, \mathrm{NCH}_{2}\right), 2.27\left(\mathrm{~s}, 3 \mathrm{H}, N C \mathrm{H}_{3}\right), 2.03-1.93\left(\mathrm{~m}, 2 \mathrm{H}, \mathrm{CH}_{2}\right), 1.70-1.57(\mathrm{~m}$, $\left.4 \mathrm{H}, 2 \mathrm{CH}_{2}\right), 1.45-1.38\left(\mathrm{~m}, 2 \mathrm{H}, \mathrm{CH}_{2}\right) ;{ }^{13} \mathrm{C} \mathrm{NMR} \delta 161.80,160.94,155.20,154.50,151.29,142.37$, $140.07,134.96,129.39,128.81,128.43,128.41,128.35,128.25,126.40,125.66,124.71,122.78$, $121.36,119.87,114.22,113.34,113.02,101.04,66.35,54.84,53.76,52.85,41.20,35.75,31.02$, 29.24, 26.33, 14.10. ES-MS $m / z: 605\left(\mathrm{M}+\mathrm{H}^{+}\right), 627(\mathrm{M}+\mathrm{Na})$. HRMS calcd for $\mathrm{C}_{38} \mathrm{H}_{40} \mathrm{~N}_{2} \mathrm{O}_{5}$ 604.2937, found 604.2940.

\section{3-(((3-((3-(4-Methoxyphenyl)-2-oxo-2H-chromen-7-}

yl)oxy)propyl)(methyl)amino)methyl)phenyl (5-phenylpentyl)carbamate (6). Using the previous procedure and starting from 54 and 5-isocyanatopentylbenzene, ${ }^{17} \mathbf{6}$ was obtained. Yield 43 $\%$, mp 123-124 ${ }^{\circ} \mathrm{C} .{ }^{1} \mathrm{H}$ NMR $\delta 7.71$ (s, $\left.1 \mathrm{H}, \mathrm{Ar}\right), 7.66$ (d, $\left.J=8.7 \mathrm{~Hz}, 2 \mathrm{H}, \mathrm{Ar}\right), 7.39$ (d, $J=8.6 \mathrm{~Hz}$, 1H, Ar), 7.27 (s, 3H, Ar), 7.18 (t, $J=7.2 \mathrm{~Hz}, 5 \mathrm{H}, \mathrm{Ar}), 6.99$ (t, $J=9.1 \mathrm{~Hz}, 3 \mathrm{H}, \mathrm{Ar}), 6.87-6.80$ (m, 2H, Ar), $5.26(\mathrm{br}, 1 \mathrm{H}, \mathrm{NH}), 4.08\left(\mathrm{t}, J=6.5 \mathrm{~Hz}, 2 \mathrm{H}, \mathrm{OCH}_{2}\right), 3.86\left(\mathrm{~s}, 3 \mathrm{H}, \mathrm{OCH}_{3}\right), 3.52(\mathrm{~s}, 2 \mathrm{H}, \mathrm{N}-$ $\left.\mathrm{CH}_{2}-\mathrm{Ph}\right), 3.34-3.19\left(\mathrm{~m}, 2 \mathrm{H}, \mathrm{CH}_{2}\right), 2.67-2.58\left(\mathrm{~m}, 2 \mathrm{H}, \mathrm{NCH}_{2}\right), 2.58-2.49\left(\mathrm{~m}, 2 \mathrm{H}, \mathrm{NCH}_{2}\right), 2.28(\mathrm{~s}, 3 \mathrm{H}$, $\left.\mathrm{NCH}_{3}\right), 2.08-1.95\left(\mathrm{~m}, 2 \mathrm{H}, \mathrm{CH}_{2}\right), 1.68-1.59\left(\mathrm{~m}, 4 \mathrm{H}, 2 \mathrm{CH}_{2}\right), 1.46-1.39\left(\mathrm{~m}, 3 \mathrm{H}, \mathrm{CH}_{3}\right) ;{ }^{13} \mathrm{C} \mathrm{NMR} \delta$ $161.94,161.25,159.79,155.06,154.71,151.21,142.43,140.87,138.89,136.38,129.60,128.90$, $128.46,128.35,128.25,127.43,125.61,124.12,121.96,120.30,113.86,113.38,113.25,100.77$, $66.89,62.13,55.33,53.06,42.44,41.18,40.54,35.77,31.03,26.93,26.42$. ES-MS m/z: 635 (M + $\left.\mathrm{H}^{+}\right), 657(\mathrm{M}+\mathrm{Na})$. HRMS calcd for $\mathrm{C}_{39} \mathrm{H}_{42} \mathrm{~N}_{2} \mathrm{O}_{6} 634.3043$, found 634.3046.

3-(((3-((3-(4-Methoxyphenyl)-2-oxo-2H-chromen-6-

yl)oxy)propyl)(methyl)amino)methyl)phenyl (5-phenylpentyl)carbamate (7). Using the

previous procedure and starting from 55 and 5-isocyanatopentylbenzene, ${ }^{17} \mathbf{7}$ was obtained. Yield 29 $\%$, mp 83.2-84 ${ }^{\circ} \mathrm{C} .{ }^{1} \mathrm{H}$ NMR $\delta 7.77$ (s, 1H, Ar), 7.44-7.33 (m, 2H, Ar), 7.29-7.24 (m, 6H, Ar), 7.217.13 (m, 4H, Ar), 7.13-7.09 (m, 1H, Ar), 7.00 (d, J=7.4 Hz, 1H, Ar), 6.94 (d, J=7.8 Hz, 1H, Ar), $6.84(\mathrm{~d}, J=8.7 \mathrm{~Hz}, 2 \mathrm{H}, \mathrm{Ar}), 5.25(\mathrm{~s}, 1 \mathrm{H}, N H), 4.07\left(\mathrm{t}, J=6.7 \mathrm{~Hz}, 2 \mathrm{H}, O C H_{2}\right), 3.86\left(\mathrm{~s}, 3 \mathrm{H}, O C H_{3}\right)$, $3.52\left(\mathrm{~s}, 2 \mathrm{H}, \mathrm{N}-\mathrm{CH}_{2}-\mathrm{Ph}\right), 3.27\left(\mathrm{~d}, \mathrm{~J}=6.0 \mathrm{~Hz}, 2 \mathrm{H}, \mathrm{CH}_{2}\right), 2.68-2.58\left(\mathrm{~m}, 2 \mathrm{H}, \mathrm{NCH}_{2}\right), 2.58-2.47(\mathrm{~m}, 2 \mathrm{H}$, $\left.\mathrm{NCH}_{2}\right), 2.28\left(\mathrm{~s}, 3 \mathrm{H}, \mathrm{NCH}_{3}\right), 2.04-1.91\left(\mathrm{~m}, 2 \mathrm{H}, \mathrm{CH}_{2}\right), 1.72-1.59\left(\mathrm{~m}, 4 \mathrm{H}, 2 \mathrm{CH}_{2}\right), 1.47-1.33(\mathrm{~m}, 3 \mathrm{H}$, 
$\left.\mathrm{CH}_{3}\right) ;{ }^{13} \mathrm{C}$ NMR $\delta 162.28,160.91,159.33,155.33,154.70,151.21,142.42,140.87,140.27,136.39$ ,129.40, 128.91, 128.72, 128.36, 128.25, 125.65, 124.29, 121.95, 120.76, 120.30, 114.07, 113.47, $113.04,100.78,66.93,62.14,55.32,53.05,42.45,41.19,35.77,31.03,29.69,26.93,26.35$. ES-MS $m / z: 635\left(\mathrm{M}+\mathrm{H}^{+}\right)$. HRMS calcd for $\mathrm{C}_{39} \mathrm{H}_{42} \mathrm{~N}_{2} \mathrm{O}_{6} 634.3043$, found 634.3047.

3-(((3-((3-(4-Chlorophenyl)-2-oxo-2H-chromen-7-yl)oxy)propyl)(methyl)amino)methyl)phenyl (5-phenylpentyl)carbamate (8). Using the previous procedure and starting from $\mathbf{5 6}$ and 5isocyanatopentylbenzene, ${ }^{17} 8$ was obtained. Yield $23 \%$, mp 76-77 ${ }^{\circ} \mathrm{C} .{ }^{1} \mathrm{H}$ NMR $\delta 7.75(\mathrm{~s}, 1 \mathrm{H}, \mathrm{Ar})$, $7.66(\mathrm{~d}, J=8.0 \mathrm{~Hz}, 2 \mathrm{H}, \mathrm{Ar}), 7.49(\mathrm{~d}, J=8.2 \mathrm{~Hz}, 2 \mathrm{H}, \mathrm{Ar}), 7.14-7.16(\mathrm{~m}, 4 \mathrm{H}, \mathrm{Ar}), 7.22-7.24(\mathrm{~m}, 3 \mathrm{H}$, Ar), $7.10(\mathrm{~d}, J=7.7 \mathrm{~Hz}, 2 \mathrm{H}, \mathrm{Ar}), 6.99$ (d, $J=7.7 \mathrm{~Hz}, 2 \mathrm{H}, \mathrm{Ar}), 6.85$ (d, $J=8.0 \mathrm{~Hz}, 2 \mathrm{H}, \mathrm{Ar}), 5.22$ (br, $1 \mathrm{H}, N H), 4.06\left(\mathrm{t}, J=6.3 \mathrm{~Hz}, 2 \mathrm{H}, O C H_{2}\right), 3.27\left(\mathrm{~s}, 2 \mathrm{H}, N C H_{2}-P h\right), 3.27\left(\mathrm{~d}, J=6.8 \mathrm{~Hz}, 2 \mathrm{H}, N C H_{2}\right)$, $2.61\left(\mathrm{t}, J=15.2 \mathrm{~Hz}, 2 \mathrm{H}, \mathrm{NCH}_{2}\right), 2.52\left(\mathrm{t}, J=13.2 \mathrm{~Hz}, 2 \mathrm{H}, \mathrm{CH}_{2}-\mathrm{Ph}\right), 2.27\left(\mathrm{~s}, 3 \mathrm{H}, \mathrm{NCH}_{3}\right), 1.98(\mathrm{t}, J=$ $\left.13.6 \mathrm{~Hz}, 2 \mathrm{H}, \mathrm{CH}_{2}\right), 1.62-1.55\left(\mathrm{~m}, 4 \mathrm{H}, 2 \mathrm{CH}_{2}\right), 1.49-1.38\left(\mathrm{~m}, 2 \mathrm{H}, \mathrm{CH}_{2}\right) ;{ }^{13} \mathrm{C} \mathrm{NMR} \delta 162.46,160.80$, $155.39,154.68,151.20,142.39,140.82,140.20,134.38,133.45,129.64,128.91,128.76,128.60$, $128.35,128.25,125.67,125.61,123.24,121.95,120.29,113.62,112.92,100.82,66.95,62.12$, 53.04, 42.44, 41.17, 35.76, 31.02, 29.67, 26.91, 26.33. ES-MS m/z: $639\left(\mathrm{M}+\mathrm{H}^{+}\right), 661(\mathrm{M}+\mathrm{Na})$. HRMS calcd for $\mathrm{C}_{38} \mathrm{H}_{39} \mathrm{ClN}_{2} \mathrm{O}_{5} 638.2548$, found 638.2546.

3-((Methyl(3-((2-oxo-2H-chromen-7-yl)oxy)propyl)amino)methyl)phenyl heptylcarbamate (9). Using the previous procedure and starting from 57 and 1-isocyanatoheptane, ${ }^{18} \mathbf{9}$ was obtained. Yield $80 \%$, mp $84-85^{\circ} \mathrm{C} .{ }^{1} \mathrm{H}$ NMR $\delta 7.61(\mathrm{~d}, J=9.4 \mathrm{~Hz}, 1 \mathrm{H}, \mathrm{Ar}), 7.31(\mathrm{~d}, J=9.0 \mathrm{~Hz}, 1 \mathrm{H}, \mathrm{Ar})$, $7.22(\mathrm{dd}, J=13.9$ and $6.2 \mathrm{~Hz}, 1 \mathrm{H}, \mathrm{Ar}), 7.10(\mathrm{~s}, 1 \mathrm{H}, \mathrm{Ar}), 7.06(\mathrm{~d}, J=7.4 \mathrm{~Hz}, 1 \mathrm{H}, \mathrm{Ar}), 6.96(\mathrm{~d}, J=$ $7.8 \mathrm{~Hz}, 1 \mathrm{H}, \mathrm{Ar}), 6.77$ (d, J = 4.8 Hz, 2H, Ar), 6.21 (d, J=9.4 Hz, 1H, Ar), $5.32(\mathrm{br}, 1 \mathrm{H}, N H), 4.01$ $\left(\mathrm{t}, J=6.3 \mathrm{~Hz}, 2 \mathrm{H}, \mathrm{OCH}_{2}\right), 3.47\left(\mathrm{~s}, 2 \mathrm{H}, \mathrm{NCH}_{2}-\mathrm{Ph}\right), 3.22\left(\mathrm{dd}, J=13.2\right.$ and $\left.6.6 \mathrm{~Hz}, 2 \mathrm{H}, \mathrm{CH}_{2}\right), 2.49(\mathrm{t}$, $\left.J=6.5 \mathrm{~Hz}, 2 \mathrm{H}, \mathrm{NCH}_{2}\right), 2.23\left(\mathrm{~s}, 3 \mathrm{H}, \mathrm{NCH}_{3}\right), 2.01-1.90\left(\mathrm{~m}, 2 \mathrm{H}, \mathrm{CH}_{2}\right), 1.60-1.48\left(\mathrm{~m}, 2 \mathrm{H}, \mathrm{NCH}_{2}\right)$, 1.37-1.17 (m, 8H, $\left.2 \mathrm{CH}_{2}-\mathrm{CH}_{2}\right), 0.84\left(\mathrm{t}, \mathrm{J}=5.8 \mathrm{~Hz}, 3 \mathrm{H}, \mathrm{CH}_{3}\right) ;{ }^{13} \mathrm{C} \mathrm{NMR} \delta 162.39,161.42,155.85$, $154.72,151.18,143.58,140.59,128.90,128.61,125.62,122.02,120.32,113.20,112.72,112.29$, 
$101.21,66.84,62.05,53.05,42.36,41.27,31.71,29.79,28.91,26.83,26.76,22.56,14.05$. ES-MS $m / z: 481\left(\mathrm{M}+\mathrm{H}^{+}\right), 503(\mathrm{M}+\mathrm{Na})$. HRMS calcd for $\mathrm{C}_{28} \mathrm{H}_{36} \mathrm{~N}_{2} \mathrm{O}_{5} 480.2624$, found 480.2626.

\section{3-((Methyl(3-((6-oxo-7,8,9,10-tetrahydro-6H-benzo[c]chromen-3-}

yl)oxy)propyl)amino)methyl)phenyl heptylcarbamate (10). Using the previous procedure and starting from $\mathbf{5 1}$ and 1-isocyanatoheptane, ${ }^{18} \mathbf{1 0}$ was obtained. Yield $61 \%$, mp $86-87{ }^{\circ} \mathrm{C} .{ }^{1} \mathrm{H}$ NMR $\delta$ $7.43(\mathrm{~d}, J=9.2 \mathrm{~Hz}, 1 \mathrm{H}, \mathrm{Ar}), 7.24(\mathrm{t}, J=17.6 \mathrm{~Hz}, 1 \mathrm{H}, \mathrm{Ar}), 7.13(\mathrm{~s}, 1 \mathrm{H}, \mathrm{Ar}), 7.09$ (d, J = 7.2 Hz, 1H, Ar), $6.99(\mathrm{~d}, J=8.0 \mathrm{~Hz}, 1 \mathrm{H}, \mathrm{Ar}), 6.81(\mathrm{~d}, J=6.4 \mathrm{~Hz}, 2 \mathrm{H}, \mathrm{Ar}), 5.29(\mathrm{br}, 1 \mathrm{H}, N H), 4.03$ (t, $J=12.8$ $\left.\mathrm{Hz}, 2 \mathrm{H}, \mathrm{OCH}_{2}\right), 3.49$ (s, 2H, $\left.\mathrm{OCH}_{2}-\mathrm{Ph}\right), 3.28-3.23\left(\mathrm{~m}, 2 \mathrm{H}, \mathrm{NCH}_{2}\right), 2.75\left(\mathrm{~m}, 2 \mathrm{H}, \mathrm{CH}_{2}\right), 2.57-2.49$ (m, 4H, $\left.\mathrm{CH}_{2}, \mathrm{NCH}_{2}\right), 2.25$ (s, 3H, $\left.\mathrm{NCH}_{3}\right), 1.99-1.95\left(\mathrm{~m}, 2 \mathrm{H}, \mathrm{CH}_{2}\right), 1.85-1.79\left(\mathrm{~m}, 4 \mathrm{H}, 2 \mathrm{CH}_{2}\right), 1.58-$ $1.48\left(\mathrm{~m}, 2 \mathrm{H}, \mathrm{CH}_{2}\right), 1.31-1.28(\mathrm{~m}, 8 \mathrm{H}), 0.88\left(\mathrm{t}, J=13.2 \mathrm{~Hz}, 3 \mathrm{H}, \mathrm{CH}_{3}\right) ;{ }^{13} \mathrm{C} \mathrm{NMR} \delta 162.27,160.99$, $154.72,153.51,151.23,147.37,140.83,128.87,125.54,123.94,121.94,120.26,119.88,113.52$, $112.57,101.05,66.71,62.10,53.19,42.38,41.27,31.72,29.81,28.91,26.97,26.69,25.20,23.81$, 22.55, 21.69, 21.39, 14.03. ES-MS $m / z: 535\left(\mathrm{M}+\mathrm{H}^{+}\right), 557(\mathrm{M}+\mathrm{Na})$. HRMS calcd for $\mathrm{C}_{28} \mathrm{H}_{36} \mathrm{~N}_{2} \mathrm{O}_{5}$ 534.3094, found 534.3098.

\section{3-((Methyl(3-((5-oxo-5H-chromeno[2,3-b]pyridin-8-yl)oxy)propyl)amino)methyl)phenyl}

heptylcarbamate (11). Using the previous procedure and starting from $\mathbf{5 8}$ and 1-

isocyanatoheptane, ${ }^{18} 11$ was obtained. Yield $74 \%, \mathrm{mp} 68-69{ }^{\circ} \mathrm{C} .{ }^{1} \mathrm{H}$ NMR $\delta$ 8.76-8.67 (m, 2H, Ar), $8.22(\mathrm{~d}, J=8.9 \mathrm{~Hz}, 1 \mathrm{H}, \mathrm{Ar}), 7.45(\mathrm{dd}, J=7.4$ and $4.9 \mathrm{~Hz}, 1 \mathrm{H}, \mathrm{Ar}), 7.33-7.21(\mathrm{~m}, 1 \mathrm{H}, \mathrm{Ar}), 7.16-7.05$ (m, 2H, Ar), 7.05-6.87 (m, 3H, Ar), $5.34(\mathrm{br}, 1 \mathrm{H}, N H), 4.14\left(\mathrm{t}, J=6.5 \mathrm{~Hz}, 2 \mathrm{H}, O C H_{2}\right), 3.52(\mathrm{~s}, 2 \mathrm{H}$, $\left.\mathrm{NCH}_{2}-\mathrm{Ph}\right), 3.26\left(\mathrm{~m}, 2 \mathrm{H}, \mathrm{NCH}_{2}\right), 2.54\left(\mathrm{t}, \mathrm{J}=6.5 \mathrm{~Hz}, 2 \mathrm{H}, \mathrm{NCH}_{2}\right), 2.29\left(\mathrm{~s}, 3 \mathrm{H}, N C H_{3}\right), 2.10-1.91(\mathrm{~m}$, 2H, $\left.\mathrm{CH}_{2}\right), 1.58-1.49\left(\mathrm{~m}, 2 \mathrm{H}, \mathrm{CH}_{2}\right), 1.39-1.24\left(\mathrm{~m}, 8 \mathrm{H}, 2 \mathrm{CH}_{2}-\mathrm{CH}_{2}\right), 0.88\left(\mathrm{t}, \mathrm{J}=6.8 \mathrm{~Hz}, 3 \mathrm{H}, \mathrm{CH}_{3}\right)$; ${ }^{13} \mathrm{C}$ NMR $\delta 176.86,165.69,160.93,157.87,153.68,151.56,142.41,137.59,129.25,128.41$, $125.96,122.35,121.33,120.64,119.88,117.33,115.51,114.86,101.56,67.43,62.53,53.27,42.82$, 41.64, 41.02, 32.07, 30.19, 29.30, 27.14, 22.91, 14.39. ES-MS m/z: $532\left(\mathrm{M}+\mathrm{H}^{+}\right), 554(\mathrm{M}+\mathrm{Na})$. HRMS calcd for $\mathrm{C}_{31} \mathrm{H}_{37} \mathrm{~N}_{3} \mathrm{O}_{5}$ 531.2733, found 531.2738. 


\section{3-((Methyl(3-((2-oxo-2H-chromen-7-yl)oxy)propyl)amino)methyl)phenyl (4-}

hexylphenyl)carbamate (12). Using the previous procedure and starting from 57 and 1-hexyl-4isocyanatobenzene (see SI), 12 was obtained. Yield $43 \%$, mp 93-94 ${ }^{\circ} \mathrm{C} .{ }^{1} \mathrm{H}$ NMR $\delta 7.61(\mathrm{~d}, J=9.6$ $\mathrm{Hz}, 1 \mathrm{H}, \mathrm{Ar}), 7.39$ (d, $J=8 \mathrm{~Hz}, 2 \mathrm{H}, \mathrm{Ar}), 7.32(\mathrm{~d}, J=10.8 \mathrm{~Hz}, 1 \mathrm{H}, \mathrm{Ar}), 7.26$ (d, $J=8 \mathrm{~Hz}, 1 \mathrm{H}, \mathrm{Ar})$, $7.20(\mathrm{~s}, 2 \mathrm{H}, \mathrm{Ar}), 7.14-7.11(\mathrm{~m}, 2 \mathrm{H}, \mathrm{Ar}), 7.04(\mathrm{~d}, J=8.0 \mathrm{~Hz}, 1 \mathrm{H}, \mathrm{Ar}), 6.81(\mathrm{~d}, J=10.0 \mathrm{~Hz}, 1 \mathrm{H}, \mathrm{Ar})$, $6.24(\mathrm{~d}, J=9.2 \mathrm{~Hz}, 1 \mathrm{H}, \mathrm{Ar}), 5.31(\mathrm{br}, 1 \mathrm{H}, \mathrm{NH}), 4.06\left(\mathrm{t}, J=12.8 \mathrm{~Hz}, 2 \mathrm{H}, O C H_{2}\right), 3.51(\mathrm{~s}, 2 \mathrm{H}$, $\left.\mathrm{NCH}_{2}-\mathrm{Ph}\right), 2.58-2.51\left(\mathrm{~m}, 4 \mathrm{H}, \mathrm{NCH}_{2}\right.$ and $\left.\mathrm{CH}_{2}\right), 2.26\left(\mathrm{~s}, 3 \mathrm{H}, \mathrm{NCH}_{3}\right), 1.98-1.95\left(\mathrm{~m}, 2 \mathrm{H}, \mathrm{CH}_{2}\right), 1.60-$ $1.57\left(\mathrm{~m}, 2 \mathrm{H}, \mathrm{CH}_{2}\right), 1.33-1.29\left(\mathrm{~m}, 6 \mathrm{H}, 3 \mathrm{CH}_{2}\right), 0.88\left(\mathrm{t}, \mathrm{J}=13.6 \mathrm{~Hz}, 3 \mathrm{H}, \mathrm{CH}_{3}\right) ;{ }^{13} \mathrm{C} \mathrm{NMR} \delta 162.46$, $161.51,155.89,150.80,143.54,142.41,141.09,138.16,135.12,128.99,128.92,128.60,125.96$, $121.98,120.30,118.88,118.68,113.25,112.75,112.30,101.28,66.79,62.11,53.02,42.44,35.27$, 31.69, 31.46, 28.88, 26.91, 22.58, 14.06. ES-MS $m / z: 543\left(\mathrm{M}+\mathrm{H}^{+}\right), 565(\mathrm{M}+\mathrm{Na})$. HRMS calcd for $\mathrm{C}_{33} \mathrm{H}_{38} \mathrm{~N}_{2} \mathrm{O}_{5} 542.2781$, found 542.2783.

\section{3-((Methyl(3-((2-oxo-2H-chromen-7-yl)oxy)propyl)amino)methyl)phenyl (6-}

phenylhexyl)carbamate (13). Using the previous procedure and starting from 57 and 6isocyanatohexyl)benzene (see SI), 13 was obtained. Yield $35 \%$, oil. ${ }^{1} \mathrm{H}$ NMR $\delta 7.63(\mathrm{~d}, J=9.2 \mathrm{~Hz}$, 1H, Ar), 7.34 (d, $J=8.8 \mathrm{~Hz}, 1 \mathrm{H}, \mathrm{Ar}), 7.29-7.24(\mathrm{~m}, 3 \mathrm{H}, \mathrm{Ar}), 7.17-7.13$ (m, 4H, Ar), 7.09 (d, $J=8$ $\mathrm{Hz}, 1 \mathrm{H}, \mathrm{Ar}), 6.97(\mathrm{~d}, J=8.0 \mathrm{~Hz}, 1 \mathrm{H}, \mathrm{Ar}), 6.81(\mathrm{~d}, J=7.6 \mathrm{~Hz}, 2 \mathrm{H}, \mathrm{Ar}), 6.25(\mathrm{~d}, J=9.6 \mathrm{~Hz}, 1 \mathrm{H}, \mathrm{Ar})$, $5.23(\mathrm{br}, 1 \mathrm{H}, \mathrm{NH}), 4.04\left(\mathrm{t}, \mathrm{J}=13.2 \mathrm{~Hz}, 2 \mathrm{H}, \mathrm{NCH}_{2}\right), 3.49\left(\mathrm{~s}, 2 \mathrm{H}, \mathrm{NCH}_{2}-\mathrm{Ph}\right), 3.27-3.23(\mathrm{~m}, 4 \mathrm{H}$, $\left.\mathrm{NCH}_{2}, \mathrm{CH}_{2}\right), 2.60\left(\mathrm{t}, \mathrm{J}=13.6 \mathrm{~Hz}, 2 \mathrm{H}, \mathrm{CH}_{2}\right), 2.51\left(\mathrm{t}, \mathrm{J}=13.2 \mathrm{~Hz}, 2 \mathrm{H}, \mathrm{CH}_{2}\right), 2.26(\mathrm{~s}, 3 \mathrm{H}, \mathrm{NCH})$, $1.98\left(\mathrm{~d}, J=13.2 \mathrm{~Hz}, 2 \mathrm{H}, C_{2}\right), 1.64-1.38\left(\mathrm{~m}, 4 \mathrm{H}, 2 \mathrm{CH}_{2}\right), 1.38-1.34\left(\mathrm{~m}, 6 \mathrm{H}, 3 \mathrm{CH}_{2}\right), 1.13(\mathrm{t}, J=$ 14.4 Hz, 2H, $\left.\mathrm{CH}_{2}\right) ;{ }^{13} \mathrm{C}$ NMR $\delta 162.43,155.91,151.21,143.54,142.62,128.91,128.60,128.35$, $128.22,128.20,125.64,125.60,125.57,122.01,120.33,119.81,113.24,112.76,112.30,101.23$, $66.88,62.07,53.02,42.39,41.22,35.83,31.37,29.75,28.88,26.84,13.85$. ES-MS m/z: $543(\mathrm{M}+$ $\left.\mathrm{H}^{+}\right), 565(\mathrm{M}+\mathrm{Na}) . \mathrm{HRMS}$ calcd for $\mathrm{C}_{33} \mathrm{H}_{38} \mathrm{~N}_{2} \mathrm{O}_{5} 542.2781$, found 542.2783.

\section{3-((Methyl-(5-((2-oxo-2H-chromen-7-yl)oxy)pentyl)amino)methyl)phenyl (5-}

phenylpentyl)carbamate (14). Using the previous procedure and starting from $\mathbf{5 9}$ and 5 - 
isocyanatopentylbenzene, ${ }^{17} 14$ was obtained. Yield $35 \%$, oil. ${ }^{1} \mathrm{H}$ NMR $\delta 7.63(\mathrm{~d}, J=9.2 \mathrm{~Hz}, 1 \mathrm{H}$, Ar), $7.36(\mathrm{~d}, J=8.8 \mathrm{~Hz}, 1 \mathrm{H}, \mathrm{Ar}), 7.28-7.24(\mathrm{~m}, 3 \mathrm{H}, \mathrm{Ar}), 7.19-7.10(\mathrm{~m}, 5 \mathrm{H}, \mathrm{Ar}), 7.01$ (d, J= 7.6 Hz, 1H, Ar), 6.84-6.80 (m, 2H, Ar), 6.25 (d, $J=9.6 \mathrm{~Hz}, 1 \mathrm{H}, \mathrm{Ar}), 5.01(\mathrm{br}, 1 \mathrm{H}, N H), 3.99$ (t, $J=12.8$ $\left.\mathrm{Hz}, 2 \mathrm{H}, \mathrm{OCH}_{2}\right), 3.47$ (s, 2H, $\left.\mathrm{NCH}_{2}-\mathrm{Ph}\right), 3.27$ (d, J=15.4 Hz, 2H, NCH $), 2.62(\mathrm{t}, J=15.2 \mathrm{~Hz}, 2 \mathrm{H}$, $\left.\mathrm{NCH}_{2}\right), 2.41\left(\mathrm{t}, \mathrm{J}=14 \mathrm{~Hz}, 2 \mathrm{H}, \mathrm{CH}_{2}\right), 2.19\left(\mathrm{~s}, 3 \mathrm{H}, \mathrm{NCH}_{3}\right), 1.81\left(\mathrm{t}, \mathrm{J}=14.4 \mathrm{~Hz}, 2 \mathrm{H}, \mathrm{CH}_{2}\right), 1.68-1.47$ $\left(\mathrm{m}, 8 \mathrm{H}, 4 \mathrm{CH}_{2}\right), 1.41-1.38\left(\mathrm{~m}, 2 \mathrm{H}, \mathrm{CH}_{2}\right) ;{ }^{13} \mathrm{C} \mathrm{NMR} \delta 162.38,161.27,155.88,154.62,151.08$, $143.44,142.35,140.80,128.90,128.66,128.35,128.26,125.68,122.01,120.10,119.81,112.94$, $112.85,112.34,101.33,68.51,61.95,57.14,42.27,41.15,35.75,31.01,29.68,28.79,27.02,26.32$, 23.70. ES-MS $m / z$ : $557\left(\mathrm{M}+\mathrm{H}^{+}\right)$. HRMS calcd for $\mathrm{C}_{34} \mathrm{H}_{40} \mathrm{~N}_{2} \mathrm{O}_{5}$ 556.2937, found 556.2933.

\section{3-((Methyl-(5-((2-oxo-2H-chromen-7-yl)oxy)pentyl)amino)methyl)phenyl heptylcarbamate}

(15). Using the previous procedure and starting from $\mathbf{5 9}$ and 1-isocyanatoheptane, ${ }^{18} \mathbf{1 5}$ was obtained. Yield $51 \%$, oil. ${ }^{1} \mathrm{H}$ NMR $\delta 7.64(\mathrm{~d}, J=9.2 \mathrm{~Hz}, 1 \mathrm{H}, \mathrm{Ar}), 7.36(\mathrm{~d}, J=8 \mathrm{~Hz}, 1 \mathrm{H}, \mathrm{Ar}), 7.27$ (t, $J=15.6 \mathrm{~Hz}, 1 \mathrm{H}, \mathrm{Ar}), 7.14-7.10(\mathrm{~m}, 2 \mathrm{H}, \mathrm{Ar}), 7.01$ (d, $J=7.6 \mathrm{~Hz}, 1 \mathrm{H}, \mathrm{Ar}), 6.83-6.79$ (m, 2H, Ar), 5.17 (br, $1 \mathrm{H}, \mathrm{NH}), 3.99$ (t, $\left.J=12.8 \mathrm{~Hz}, 2 \mathrm{H}, \mathrm{CH}_{2}-\mathrm{O}\right), 3.47$ (s, $2 \mathrm{H}, \mathrm{NCH}_{2}-\mathrm{Ph}$ ), 3.26-3.21 (d, J= 7.0 $\left.\mathrm{Hz}, 2 \mathrm{H}, \mathrm{NCH}_{2}\right), 2.39\left(\mathrm{t}, \mathrm{J}=13.6 \mathrm{~Hz}, 2 \mathrm{H}, \mathrm{NCH}_{2}\right), 2.19\left(\mathrm{~s}, 3 \mathrm{H}, \mathrm{NCH}_{3}\right), 1.84-1.77\left(\mathrm{~m}, 2 \mathrm{H}, \mathrm{CH}_{2}\right), 1.57-$ $1.46\left(\mathrm{~m}, 6 \mathrm{H}, 3 \mathrm{CH}_{2}\right), 1.32-1.28\left(\mathrm{~m}, 8 \mathrm{H}, 2 \mathrm{CH}_{2}-\mathrm{CH}_{2}\right), 0.88\left(\mathrm{t}, \mathrm{J}=13.2 \mathrm{~Hz}, 3 \mathrm{H}, \mathrm{CH}_{3}\right) ;{ }^{13} \mathrm{C} \mathrm{NMR} \delta$ $162.38,161.31,155.86,154.66,151.09,143.50,128.89,128.69,125.66,122.02,120.11,119.83$, $112.93,112.83,112.33,101.30,68.51,61.96,57.15,42.28,41.25,31.71,29.81,28.91,28.80$, 27.04, 26.69, 23.70, 22.56, 14.06. ES-MS m/z: $509\left(\mathrm{M}+\mathrm{H}^{+}\right), 531(\mathrm{M}+\mathrm{Na}), 547(\mathrm{M}+\mathrm{K}) . \mathrm{HRMS}$ calcd for $\mathrm{C}_{30} \mathrm{H}_{40} \mathrm{~N}_{2} \mathrm{O}_{5}$ 508.2937, found 508.2934.

\section{3-((Methyl-(5-((5-oxo-5H-chromeno[2,3-b]pyridin-8-yl)oxy)pentyl)amino)methyl)phenyl}

heptylcarbamate (16). Using the previous procedure and starting from 60 and 1isocyanatoheptane, ${ }^{18} \mathbf{1 6}$ was obtained. Yield $75 \%, \mathrm{mp} 73-74{ }^{\circ} \mathrm{C} .{ }^{1} \mathrm{H}$ NMR $\delta 7.43(\mathrm{~d}, J=8.7 \mathrm{~Hz}$, 1H, Ar), 7.31-7.27 (m, 1H, Ar), 7.16-7.08 (m, 2H, Ar), 7.00 (d, J=7.3 Hz, 1H, Ar), 6.85-6.76 (m, 2H, Ar), $5.05(\mathrm{br}, 1 \mathrm{H}, \mathrm{NH}), 3.98\left(\mathrm{t}, J=6.4 \mathrm{~Hz}, 2 \mathrm{H}, \mathrm{CH}_{2}\right), 3.48\left(\mathrm{~s}, 2 \mathrm{H}, \mathrm{CH}_{2}\right), 3.24(\mathrm{dd}, J=13.2$ and $\left.6.6 \mathrm{~Hz}, 2 \mathrm{H}, \mathrm{NHCH}_{2}\right), 2.74\left(\mathrm{t}, \mathrm{J}=5.6 \mathrm{~Hz}, 2 \mathrm{H}, \mathrm{CH}_{2}\right), 2.56\left(\mathrm{t}, \mathrm{J}=5.6 \mathrm{~Hz}, 2 \mathrm{H}, \mathrm{CH}_{2}\right), 2.39(\mathrm{t}, J=6.9$ 
$\left.\mathrm{Hz}, 2 \mathrm{H}, \mathrm{CH}_{2}\right), 2.18\left(\mathrm{~s}, 3 \mathrm{H}, \mathrm{NCH}_{3}\right), 1.92-1.71\left(\mathrm{~m}, 6 \mathrm{H}, 3 \mathrm{CH}_{2}\right), 1.61-1.42\left(\mathrm{~m}, 6 \mathrm{H}, 3 \mathrm{CH}_{2}\right), 1.37-1.24$ $\left(\mathrm{m}, 8 \mathrm{H}, 4 \mathrm{CH}_{2}\right), 0.88\left(\mathrm{t}, J=6.4 \mathrm{~Hz}, 3 \mathrm{H}, \mathrm{CH}_{3}\right) ;{ }^{13} \mathrm{C} \mathrm{NMR} \delta 162.12,160.87,153.41,151.00,147.20$, $140.84,128.80,125.57,123.92,121.89,120.26,119.97,119.81,113.48,112.23,101.04,68.27$, $61.89,57.11,42.21,41.17,31.63,29.73,28.82,27.00,26.61,25.12,23.73,23.65,22.48,21.62$, 21.31, 17.79, 13.96. ES-MS m/z: $563\left(\mathrm{M}+\mathrm{H}^{+}\right), 585(\mathrm{M}+\mathrm{Na})$. HRMS calcd for $\mathrm{C}_{30} \mathrm{H}_{40} \mathrm{~N}_{2} \mathrm{O}_{5}$ 559.3046, found 559.3045.

\section{3-((Methyl-(5-((5-oxo-5H-chromeno[2,3-b]pyridin-8-yl)oxy)pentyl)amino)methyl)phenyl} heptylcarbamate (17). Using the previous procedure and starting from 61 and 1isocyanatoheptane, ${ }^{18} 17$ was obtained. Yield $56 \%$, colorless oil. ${ }^{1} \mathrm{H}$ NMR $\delta 8.71(\mathrm{~d}, J=6.8 \mathrm{~Hz}, 2 \mathrm{H}$, Ar), $8.23(\mathrm{~d}, J=8.8 \mathrm{~Hz}, 1 \mathrm{H}, \mathrm{Ar}), 7.42(\mathrm{~d}, J=5.2 \mathrm{~Hz}, 1 \mathrm{H}, \mathrm{Ar}), 7.28-7.32(\mathrm{~m}, 1 \mathrm{H}, \mathrm{Ar}), 7.14-7.11(\mathrm{~m}$, 2H, Ar), 7.01-6.96 (m, 3H, Ar), $5.03(\mathrm{br}, 1 \mathrm{H}, \mathrm{NH}), 4.09$ (t, $\left.J=13.2 \mathrm{~Hz}, 2 \mathrm{H}, \mathrm{CH}_{2}\right), 3.48\left(\mathrm{~s}, 2 \mathrm{H}, \mathrm{CH}_{2}\right)$, 3.27-3.22 (m, 2H, $\left.\mathrm{NH}-\mathrm{CH}_{2}\right), 2.40\left(\mathrm{t}, \mathrm{J}=13.6 \mathrm{~Hz}, 2 \mathrm{H}, \mathrm{CH}_{2}\right), 2.20\left(\mathrm{~s}, 3 \mathrm{H}, \mathrm{NCH}_{3}\right), 1.88-1.82(\mathrm{~m}, 2 \mathrm{H}$, $\left.\mathrm{CH}_{2}\right), 1.57-1.53\left(\mathrm{~m}, 6 \mathrm{H}, 3 \mathrm{CH}_{2}\right), 1.31-1.28\left(\mathrm{~m}, 8 \mathrm{H}, 4 \mathrm{CH}_{2}\right), 0.88\left(\mathrm{t}, \mathrm{J}=13.2 \mathrm{~Hz}, 3 \mathrm{H}, \mathrm{CH}_{3}\right) ;{ }^{13} \mathrm{C}$ NMR $\delta 176.49,165.30,160.49,157.72,154.59,153.42$,151.12, 137.18, 128.93, 128.16, 125.73, $122.06,120.95,120.17,119.81,116.94,115.20,114.28,101.26,68.76,61.91,57.05,42.21,41.26$, $31.69,29.81,28.88,28.73,26.94,26.68,23.69,22.53,14.01$. ES-MS $m / z: 560\left(\mathrm{M}+\mathrm{H}^{+}\right), 582(\mathrm{M}+$ Na). HRMS calcd for $\mathrm{C}_{33} \mathrm{H}_{41} \mathrm{~N}_{3} \mathrm{O}_{5} 559.3046$, found 559.3045.

\section{4-((4-(((2-Oxo-2H-chromen-7-yl)oxy)methyl)-1H-1,2,3-triazol-1-yl)methyl)phenyl (5-}

phenylpentyl)carbamate (18). Using the previous procedure and starting from 64a and 5isocyanatopentylbenzene, ${ }^{17} \mathbf{1 8}$ was obtained. Yield $20 \%$, mp $129-130{ }^{\circ} \mathrm{C}(\mathrm{MeOH}) .{ }^{1} \mathrm{H}$ NMR $\delta 7.61$ (d, $J=9.5 \mathrm{~Hz}, 1 \mathrm{H}, \mathrm{Ar}), 7.54$ (s, 1H, Ar), 7.35 (d, $J=8.5 \mathrm{~Hz}, 1 \mathrm{H}, \mathrm{Ar}), 7.28-7.25$ (m, 4H, Ar), 7.197.07 (m, 4H, Ar), 6.95-6.82 (m, 2H, Ar), 6.24 (d, J=9.5 Hz, 1H, Ar), 5.50 (s, 2H, $\left.C H_{2}\right), 5.20$ (s, 2H, $\left.\mathrm{CH}_{2}\right), 5.04(\mathrm{br}, 1 \mathrm{H}, \mathrm{NH}), 3.23\left(\mathrm{dd}, J=13.3\right.$ and $\left.6.8 \mathrm{~Hz}, 2 \mathrm{H}, \mathrm{CH}_{2}\right), 2.61(\mathrm{t}, J=7.6 \mathrm{~Hz}, 2 \mathrm{H}$, $\left.\mathrm{CH}_{2}\right), 1.72-1.49\left(\mathrm{~m}, 4 \mathrm{H}, \mathrm{CH}_{2}-\mathrm{CH}_{2}\right), 1.41-1.34\left(\mathrm{~m}, 2 \mathrm{H}, \mathrm{CH}_{2}\right) ;{ }^{13} \mathrm{C} \mathrm{NMR} \delta 161.27,161.06,155.68$, $154.16,151.46,143.29,142.29,131.05,129.23,128.87,128.35,128.28,125.72,122.86,122.37$, 
113.44, 112.97, 112.73, 102.10, 62.30, 53.73, 41.20, 35.74, 30.99, 29.64, 26.28. ES-MS m/z: 539 $\left(\mathrm{M}+\mathrm{H}^{+}\right)$. HRMS calcd for $\mathrm{C}_{31} \mathrm{H}_{30} \mathrm{~N}_{4} \mathrm{O}_{5} 538.2216$, found 538.2219.

3-((4-(((2-Oxo-2H-chromen-7-yl)oxy)methyl)-1H-1,2,3-triazol-1-yl)methyl)phenyl (5phenylpentyl)carbamate (19). Using the previous procedure and starting from 64b and 5isocyanatopentylbenzene, ${ }^{17} 19$ was obtained. Yield $22 \%$, oil. ${ }^{1} \mathrm{H}$ NMR $\delta 7.61$ (s, 1H, Ar), 7.58 (d, $J$ $=7.8 \mathrm{~Hz}, 1 \mathrm{H}, \mathrm{Ar}), 7.33(\mathrm{t}, J=8.2 \mathrm{~Hz}, 2 \mathrm{H}, \mathrm{Ar}), 7.25(\mathrm{dd}, J=9.6$ and $5.4 \mathrm{~Hz}, 2 \mathrm{H}, \mathrm{Ar}), 7.18-715(\mathrm{~m}$, 3H, Ar), 7.13-7.00 (m, 3H, Ar), 6.89-6.75 (m, 2H, Ar), 6.23 (d, J=9.5 Hz, 1H, Ar), 5.51 (s, 2H, $\left.\mathrm{CH}_{2}\right), 5.20\left(\mathrm{~s}, 2 \mathrm{H}, \mathrm{CH}_{2}\right), 5.13(\mathrm{br}, 1 \mathrm{H}, \mathrm{NH}), 3.23\left(\mathrm{dd}, \mathrm{J}=13.3\right.$ and $\left.6.8 \mathrm{~Hz}, 2 \mathrm{H}, \mathrm{CH}_{2}\right), 2.61(\mathrm{t}, J=7.7$ $\left.\mathrm{Hz}, 2 \mathrm{H}, \mathrm{CH}_{2}\right), 1.63-1.55\left(\mathrm{~m}, 4 \mathrm{H}, \mathrm{CH}_{2}-\mathrm{CH}_{2}\right), 1.39-1.17\left(\mathrm{~m}, 2 \mathrm{H}, \mathrm{CH}_{2}\right) ;{ }^{13} \mathrm{C}$ NMR $\delta 161.31,161.13$, $155.71,154.24,151.60,143.36,142.35,135.59,130.10,128.92,128.40,128.33,125.76,124.81$, $123.08,122.24,121.42,113.47,113.01,112.86,102.12,62.36,53.90,41.26,35.79,31.04,29.67$, 26.35. ES-MS $m / z: 539\left(\mathrm{M}+\mathrm{H}^{+}\right)$. HRMS calcd for $\mathrm{C}_{31} \mathrm{H}_{30} \mathrm{~N}_{4} \mathrm{O}_{5}$ 538.2216, found 538.2215.

\section{4-((4-(((2-Oxo-2H-chromen-7-yl)oxy)methyl)-1H-1,2,3-triazol-1-yl)methyl)phenyl}

heptylcarbamate (20). Using the previous procedure and starting from 64a and 1isocyanatoheptane, ${ }^{18} \mathbf{2 0}$ was obtained. Yield $22 \%$, mp 152-153 ${ }^{\circ} \mathrm{C} .{ }^{1} \mathrm{H}$ NMR $\delta 7.61(\mathrm{~d}, J=9.5 \mathrm{~Hz}$, 1H, Ar), 7.54 (s, 1H, Ar), 7.35 (d, J=8.7 Hz, 1H, Ar), 7.30-7.20 (m, 2H, Ar), 7.13 (d, J=8.3 Hz, 2H, Ar), $6.90(\mathrm{~d}, J=7.6 \mathrm{~Hz}, 2 \mathrm{H}, \mathrm{Ar}), 6.24(\mathrm{~d}, J=9.5 \mathrm{~Hz}, 1 \mathrm{H}, \mathrm{Ar}), 5.51\left(\mathrm{~s}, 2 \mathrm{H}, C H_{2}\right), 5.21(\mathrm{~s}, 2 \mathrm{H}$, $\mathrm{CH}_{2}$ ), $5.02(\mathrm{br}, 1 \mathrm{H}, \mathrm{NH}), 3.24\left(\mathrm{dd}, \mathrm{J}=13.4\right.$ and $\left.6.7 \mathrm{~Hz}, 2 \mathrm{H}, \mathrm{CH}_{2}\right), 1.32-1.20\left(\mathrm{~m}, 8 \mathrm{H}, 4 \mathrm{CH}_{2}\right), 0.87$ $\left(\mathrm{t}, J=6.6 \mathrm{~Hz}, 3 \mathrm{H}, \mathrm{CH}_{3}\right) ;{ }^{13} \mathrm{C} \mathrm{NMR} \delta 161.26,161.06,155.66,154.16,153.37,152.26,151.47$, $143.30,131.01,129.22,128.8,122.3,113.41,112.95,112.73,102.07,62.25,53.80,41.30,31.69$, 29.74, 28.88, 26.66, 22.55, 14.04. ES-MS m/z: $491\left(\mathrm{M}+\mathrm{H}^{+}\right), 513(\mathrm{M}+\mathrm{Na})$. HRMS calcd for $\mathrm{C}_{27} \mathrm{H}_{30} \mathrm{~N}_{4} \mathrm{O}_{5} 490.2216$, found 490.2218 .

\section{3-((4-(((2-Oxo-2H-chromen-7-yl)oxy)methyl)-1H-1,2,3-triazol-1-yl)methyl)phenyl}

heptylcarbamate (21). Using the previous procedure and starting from $64 \mathrm{~b}$ and 1isocyanatoheptane, ${ }^{18} 21$ was obtained. Yield $32 \%, \mathrm{mp}>250{ }^{\circ} \mathrm{C} .{ }^{1} \mathrm{H} \mathrm{NMR} \delta 7.62(\mathrm{~d}, J=9.5 \mathrm{~Hz}, 1 \mathrm{H}$, Ar), 7.58 (s, 1H, Ar), 7.35 (t, $J=9.4 \mathrm{~Hz}, 2 \mathrm{H}, \mathrm{Ar}), 7.15-7.04$ (m, 3H, Ar), 6.94-6.86 (m, 2H, Ar), 
$6.25(\mathrm{~d}, J=9.5 \mathrm{~Hz}, 1 \mathrm{H}, \mathrm{Ar}), 5.52\left(\mathrm{~s}, 2 \mathrm{H}, C_{2}\right), 5.22\left(\mathrm{~s}, 2 \mathrm{H}, C H_{2}\right), 5.14(\mathrm{br}, 1 \mathrm{H}, N H), 3.24(\mathrm{dd}, J=$ 13.4 and $\left.6.7 \mathrm{~Hz}, 2 \mathrm{H}, \mathrm{CH}_{2}\right), 1.40-1.20\left(\mathrm{~m}, 10 \mathrm{H}, 5 \mathrm{CH}_{2}\right), 0.88\left(\mathrm{t}, \mathrm{J}=6.2 \mathrm{~Hz}, 3 \mathrm{H}, \mathrm{CH}_{3}\right) ;{ }^{13} \mathrm{C} \mathrm{NMR} \delta$ $161.23,161.05,155.64,154.16,151.55,143.38,143.28,135.50,130.02,128.84,124.72,122.95$, $122.16,121.36,113.40,112.93,112.77,102.04,62.29,53.82,41.28,31.67,29.72,28.86,26.65$, 22.53, 14.02. ES-MS m/z: $491\left(\mathrm{M}+\mathrm{H}^{+}\right), 513(\mathrm{M}+\mathrm{Na}), 529(\mathrm{M}+\mathrm{K}) . \mathrm{HRMS}$ calcd for $\mathrm{C}_{27} \mathrm{H}_{30} \mathrm{~N}_{4} \mathrm{O}_{5}$ 490.2216, found 490.2220.

\section{4-(4-(((2-Oxo-2H-chromen-7-yl)oxy)methyl)-1H-1,2,3-triazol-1-yl)phenyl (5-}

phenylpentyl)carbamate (22). Using the previous procedure and starting from 65a and 5isocyanatopentylbenzene, ${ }^{17} 22$ was obtained. Yield $50 \%$, mp $168-169{ }^{\circ} \mathrm{C}(\mathrm{MeOH}) .{ }^{1} \mathrm{H}$ NMR $\delta 8.06$ (s, 1H, Ar), 7.73 (d, $J=8.8 \mathrm{~Hz}, 2 \mathrm{H}, \mathrm{Ar}), 7.65$ (d, $J=9.5 \mathrm{~Hz}, 1 \mathrm{H}, \mathrm{Ar}), 7.45-7.37$ (m, 1H, Ar), 7.32$7.26(\mathrm{~m}, 4 \mathrm{H}, \mathrm{Ar}), 7.20(\mathrm{t}, J=6.8 \mathrm{~Hz}, 3 \mathrm{H}, \mathrm{Ar}), 6.98(\mathrm{dd}, J=5.5$ and $2.3 \mathrm{~Hz}, 2 \mathrm{H}, \mathrm{Ar}), 6.29(\mathrm{~d}, J=9.5$ $\mathrm{Hz}, 1 \mathrm{H}, \mathrm{Ar}), 5.35\left(\mathrm{~s}, 2 \mathrm{H}, \mathrm{CH}_{2}\right), 5.09(\mathrm{br}, 1 \mathrm{H}, \mathrm{NH}), 3.29\left(\mathrm{dd}, \mathrm{J}=13.3\right.$ and $\left.6.8 \mathrm{~Hz}, 2 \mathrm{H}, \mathrm{CH}_{2}\right), 2.65$ (t, $\left.J=7.6 \mathrm{~Hz}, 2 \mathrm{H}, \mathrm{CH}_{2}\right), 1.74-1.63\left(\mathrm{~m}, 4 \mathrm{H}, \mathrm{CH}_{2}-\mathrm{CH}_{2}\right), 1.51-1.37(\mathrm{~m}, 2 \mathrm{H} \mathrm{CH})_{2} ;{ }^{13} \mathrm{C} \mathrm{NMR} \delta 161.18$, $160.99,155.71,153.89,151.34,143.71,143.24,142.26,133.79,128.93,128.34,128.28,125.72$, $122.89,121.64,121.24,113.54,113.07,112.69,102.14,62.23,41.24,35.73,30.97,29.63,26.27$. ES-MS m/z: $525\left(\mathrm{M}+\mathrm{H}^{+}\right)$. HRMS calcd for $\mathrm{C}_{30} \mathrm{H}_{28} \mathrm{~N}_{4} \mathrm{O}_{5}$ 524.2061, found 524.2063.

\section{3-(4-(((2-Oxo-2H-chromen-7-yl)oxy)methyl)-1H-1,2,3-triazol-1-yl)phenyl (5-}

phenylpentyl)carbamate (23). Using the previous procedure and starting from $65 \mathrm{~b}$ and 5isocyanatopentylbenzene, ${ }^{17} \mathbf{2 3}$ was obtained. Yield $51 \%$, mp 132-132 ${ }^{\circ} \mathrm{C} .{ }^{1} \mathrm{H}$ NMR $\delta 8.09$ (s, $1 \mathrm{H}$, Ar), $7.65(\mathrm{~d}, J=9.5 \mathrm{~Hz}, 1 \mathrm{H}, \mathrm{Ar}), 7.60(\mathrm{~d}, J=6.8 \mathrm{~Hz}, 2 \mathrm{H}, \mathrm{Ar}), 7.51(\mathrm{t}, J=8.2 \mathrm{~Hz}, 1 \mathrm{H}, \mathrm{Ar}), 7.41(\mathrm{~d}$, $J=9.5 \mathrm{~Hz}, 1 \mathrm{H}, \mathrm{Ar}), 7.32-7.15(\mathrm{~m}, 6 \mathrm{H}, \mathrm{Ar}), 6.97(\mathrm{~d}, J=6.4 \mathrm{~Hz}, 2 \mathrm{H}, \mathrm{Ar}), 6.28(\mathrm{~d}, J=9.5 \mathrm{~Hz}, 1 \mathrm{H}$, $\mathrm{Ar}), 5.35\left(\mathrm{~s}, 2 \mathrm{H}, \mathrm{CH}_{2}\right), 5.11(\mathrm{br}, 1 \mathrm{H}, \mathrm{NH}), 3.28\left(\mathrm{dd}, J=13.3\right.$ and $\left.6.8 \mathrm{~Hz}, 2 \mathrm{H}, \mathrm{CH}_{2}-\mathrm{N}\right), 2.65(\mathrm{t}, J=$ $\left.7.6 \mathrm{~Hz}, 2 \mathrm{H}, \mathrm{CH}_{2}\right), 1.73-1.61\left(\mathrm{~m}, 4 \mathrm{H}, \mathrm{CH}_{2}-\mathrm{CH}_{2}\right), 1.43\left(\mathrm{dd}, \mathrm{J}=15.2\right.$ and $\left.8.1 \mathrm{~Hz}, 2 \mathrm{H}, \mathrm{CH}_{2}\right) ;{ }^{13} \mathrm{C} \mathrm{NMR}$ $\delta 161.15,160.99,155.72,153.73,151.91,143.84,143.24,137.35,130.44,128.95,128.35,128.29$, $125.73,122.10,121.21,117.12,114.34,113.56,113.09,112.67,102.19,62.24,41.26,35.73,30.97$, 29.62, 26.27. ES-MS m/z: $525\left(\mathrm{M}+\mathrm{H}^{+}\right)$. HRMS calcd for $\mathrm{C}_{30} \mathrm{H}_{28} \mathrm{~N}_{4} \mathrm{O}_{5}$ 524.2061, found 524.2065. 


\section{4-(4-(((2-Oxo-2H-chromen-7-yl)oxy)methyl)-1H-1,2,3-triazol-1-yl)phenyl heptylcarbamate}

(24). Using the previous procedure and starting from 65a and 1-isocyanatoheptane, ${ }^{18} \mathbf{2 4}$ was obtained. Yield $64 \%$, mp 180-181 ${ }^{\circ} \mathrm{C} .{ }^{1} \mathrm{H}$ NMR $\delta 8.05$ (s, 1H, Ar), 7.71 (d, J=8.8 Hz, 2H, Ar), $7.64(\mathrm{~d}, J=9.5 \mathrm{~Hz}, 1 \mathrm{H}, \mathrm{Ar}), 7.43-7.36(\mathrm{~m}, 1 \mathrm{H}, \mathrm{Ar}), 7.31(\mathrm{~d}, J=8.8 \mathrm{~Hz}, 2 \mathrm{H}, \mathrm{Ar}), 6.97$ (dd, $J=4.4$ and $2.2 \mathrm{~Hz}, 2 \mathrm{H}, \mathrm{Ar}), 6.27(\mathrm{~d}, J=9.5 \mathrm{~Hz}, 1 \mathrm{H}, \mathrm{Ar}), 5.33\left(\mathrm{~s}, 2 \mathrm{H}, \mathrm{CH}_{2}\right), 5.11(\mathrm{br}, 1 \mathrm{H}, \mathrm{NH}), 3.28$ (dd, $J$ $=13.4$ and $\left.6.7 \mathrm{~Hz}, 2 \mathrm{H}, \mathrm{CH}_{2}-\mathrm{N}\right), 1.58-1.23\left(\mathrm{~m}, 2 \mathrm{H}, \mathrm{CH}_{2}\right), 1.31-1.18\left(\mathrm{~m}, 8 \mathrm{H}, 4 \mathrm{CH}_{2}\right), 0.89(\mathrm{t}, \mathrm{J}=6.6$ $\left.\mathrm{Hz}, 3 \mathrm{H}, \mathrm{CH}_{3}\right) ;{ }^{13} \mathrm{C} \mathrm{NMR} \delta 161.18,161.02,155.69,153.92,151.36,143.68,143.28,133.72,128.94$, $122.90,121.62,121.35,113.51,113.05,112.70,102.10,62.21,41.35,31.69,29.73,28.88,26.67$, 22.55, 14.03. ES-MS m/z: $499(\mathrm{M}+\mathrm{Na})$. HRMS calcd for $\mathrm{C}_{26} \mathrm{H}_{28} \mathrm{~N}_{4} \mathrm{O}_{5} 476.2060$, found 476.2064.

\section{3-(4-(((2-oxo-2H-chromen-7-yl)oxy)methyl)-1H-1,2,3-triazol-1-yl)phenyl heptylcarbamate} (25). Using the previous procedure and starting from $\mathbf{6 5 b}$ and 1-isocyanatoheptane,${ }^{18} \mathbf{2 5}$ was obtained. Yield $41 \%, \mathrm{mp} 127-128{ }^{\circ} \mathrm{C} .{ }^{1} \mathrm{H}$ NMR $\delta 8.09$ (s, 1H, Ar), 7.63 (d, $J=9.5 \mathrm{~Hz}, 1 \mathrm{H}, \mathrm{Ar}$ ), 7.61-7.57 (m, 2H, Ar), 7.48 (t, $J=8.1 \mathrm{~Hz}, 1 \mathrm{H}, \mathrm{Ar}), 7.39$ (d, $J=8.5 \mathrm{~Hz}, 1 \mathrm{H}, \mathrm{Ar}), 7.22$ (d, $J=8.0 \mathrm{~Hz}$, 1H, Ar), 6.98-6.94 (m, 2H, Ar), $6.26(\mathrm{~d}, J=9.4 \mathrm{~Hz}, 1 \mathrm{H}, \mathrm{Ar}), 5.32\left(\mathrm{~s}, 2 \mathrm{H}, C_{2}\right), 5.21(\mathrm{br}, 1 \mathrm{H}, N H)$, $3.26\left(\mathrm{~d}, \mathrm{~J}=6.3 \mathrm{~Hz}, 2 \mathrm{H}, \mathrm{CH}_{2}-\mathrm{N}\right), 1.59-1.51\left(\mathrm{~m}, 2 \mathrm{H}, \mathrm{CH}_{2}\right), 1.31-1-19\left(\mathrm{~m}, 8 \mathrm{H}, 4 \mathrm{CH}_{2}\right), 0.88(\mathrm{~s}, 3 \mathrm{H}$, $\left.\mathrm{CH}_{3}\right) ;{ }^{13} \mathrm{C}$ NMR $\delta 161.15,161.03,155.68,153.83,151.94,143.75,143.28,137.34,130.42,128.95$, $122.10,121.27,117.04,114.31,113.50,113.06,112.67,102.13,62.20,41.36,31.69,29.72,28.88$, 26.66, 22.55, 14.04. ES-MS m/z: $477\left(\mathrm{M}+\mathrm{H}^{+}\right), 499(\mathrm{M}+\mathrm{Na})$. HRMS calcd for $\mathrm{C}_{26} \mathrm{H}_{28} \mathrm{~N}_{4} \mathrm{O}_{5}$ 476.2060, found 476.2063 .

7-(3-Chloropropoxy)-4-methyl-2H-chromen-2-one (26). A stirred mixture of 7-hydroxy-4methyl-2H-chromen-2-one (1.26 g, $7.16 \mathrm{mmol}), 1$-bromo-3-chloropropane (1.67 g, $10.74 \mathrm{mmol})$ and $\mathrm{K}_{2} \mathrm{CO}_{3}(2.47 \mathrm{~g}, 17.89 \mathrm{mmol})$ was refluxed in acetone $(100 \mathrm{~mL})$ for $10 \mathrm{~h}$. The suspension was hot filtered and the solvent was removed under reduced pressure. After adding petroleum ether, the residue was kept in the freezer overnight and the solid that formed was filtered off, affording 26 $(1.42 \mathrm{~g}, 79 \%), \mathrm{mp} 79-80{ }^{\circ} \mathrm{C} .{ }^{1} \mathrm{H}$ NMR $\delta: 7.58(\mathrm{~d}, J=8.2 \mathrm{~Hz}, 1 \mathrm{H}), 6.95-6.81(\mathrm{~m}, 2 \mathrm{H}), 6.15(\mathrm{~s}, 1 \mathrm{H})$, $4.19(\mathrm{t}, J=11.2 \mathrm{~Hz}, 2 \mathrm{H}), 3.78(\mathrm{t}, J=11.6 \mathrm{~Hz}, 2 \mathrm{H}), 2.45(\mathrm{~s}, 3 \mathrm{H}), 2.35-2.26(\mathrm{~m}, 2 \mathrm{H})$. 
3-(3-Chloropropoxy)-7,8,9,10-tetrahydro-6H-benzo[c]chromen-6-one (27). Using the previous procedure and starting from 3-hydroxy-7,8,9,10-tetrahydro-6H-benzo[c]chromen-6-one, ${ }^{41} 27$ was obtained. Yield $78 \%, \mathrm{mp} 100-101{ }^{\circ} \mathrm{C} .{ }^{1} \mathrm{H}$ NMR $\delta 7.44(\mathrm{~d}, J=8.8 \mathrm{~Hz}, 1 \mathrm{H}) .6 .90-6.70(\mathrm{~m}, 2 \mathrm{H}), 4.07$ (t, $J=12.4 \mathrm{~Hz}, 2 \mathrm{H}), 3.85-3.70(\mathrm{~m}, 2 \mathrm{H}), 2.75(\mathrm{t}, J=11.6 \mathrm{~Hz}, 2 \mathrm{H}), 2.57-2.54(\mathrm{~m}, 2 \mathrm{H}), 2.00-1.97(\mathrm{~m}$, 2H), $1.86-1.78(\mathrm{~m}, 4 \mathrm{H})$.

3-(3-Chloropropoxy)-6H-benzo[c]chromen-6-one (28). To a suspension of DDQ (2,3-dichloro5,6-dicyano-p-benzoquinone, $2.58 \mathrm{~g}, 11.37 \mathrm{mmol})$ in anhydrous dioxane $(30 \mathrm{~mL}), 27(1.1 \mathrm{~g}, 3.79$ mmol) was added and the mixture was stirred and refluxed for $24 \mathrm{~h}$. The solution was concentrated under vacuum, then water was added and the aqueous phase was extracted with ethyl acetate $(3 \times 20$ $\mathrm{mL})$. The combined organic layers were dried and concentrated under vacuum. The crude was purified via flash column chromatography (petroleum ether/ethyl acetate 3:2), and $\mathbf{2 8}$ was obtained $(0.23 \mathrm{~g}, 21 \%), \mathrm{mp} 84-85^{\circ} \mathrm{C} .{ }^{1} \mathrm{H}$ NMR $\delta 8.35(\mathrm{~d}, J=8.8 \mathrm{~Hz}, 1 \mathrm{H}), 8.11-7.95(\mathrm{~m}, 2 \mathrm{H}), 7.83(\mathrm{t}, J=$ $8.2 \mathrm{~Hz}, 1 \mathrm{H}), 7.55(\mathrm{t}, J=6.4 \mathrm{~Hz}, 1 \mathrm{H}), 7.09-6.81(\mathrm{~m}, 2 \mathrm{H}), 4.19(\mathrm{t}, J=11.2 \mathrm{~Hz}, 2 \mathrm{H}), 3.78(\mathrm{t}, J=11.6$ $\mathrm{Hz}, 2 \mathrm{H}), 2.35-2.26(\mathrm{~m}, 2 \mathrm{H})$.

7-(3-Chloropropoxy)-3-phenyl-2H-chromen-2-one (29). A stirred mixture of 7-hydroxy-3phenyl-2H-chromen-2-one (1.7 g, $7.16 \mathrm{mmol}), 1$-bromo-3-chloropropane (1.67 g, $10.74 \mathrm{mmol})$ and $\mathrm{K}_{2} \mathrm{CO}_{3}(2.47 \mathrm{~g}, 17.89 \mathrm{mmol})$ was refluxed in acetone $(100 \mathrm{~mL})$ for 24 hours. The suspension was hot filtered and the solvent was removed under reduced pressure. After adding petroleum ether, the residue was kept in the freezer overnight and the solid that formed was filtered off, affording 29 $(1.09 \mathrm{~g}, 49 \%), \mathrm{mp} 108-110{ }^{\circ} \mathrm{C} .{ }^{1} \mathrm{H}$ NMR $\delta 7.75(\mathrm{~s}, 1 \mathrm{H}), 7.68(\mathrm{~d}, J=8.8 \mathrm{~Hz}, 2 \mathrm{H}), 7.45-737(\mathrm{~m}$, 4H), $6.87(\mathrm{~d}, J=10.9 \mathrm{~Hz}, 2 \mathrm{H}), 4.19(\mathrm{t}, J=11.8 \mathrm{~Hz}, 2 \mathrm{H}), 3.76(\mathrm{t}, J=12.2 \mathrm{~Hz}, 2 \mathrm{H}), 2.31-2.26(\mathrm{~m}$, $2 \mathrm{H})$.

7-(3-Chloropropoxy)-3-(4-methoxyphenyl)-2H-chromen-2-one (30). Using the previous procedure and starting from 7-hydroxy-3-(4-methoxyphenyl)-2H-chromen-2-one, 30 was obtained. Yield $52 \%$, mp 110-114 ${ }^{\circ} \mathrm{C} .{ }^{1} \mathrm{H}$ NMR $\delta 7.81(\mathrm{~s}, 1 \mathrm{H}), 7.51-7.25(\mathrm{~m}, 4 \mathrm{H}), 7.01-6.87(\mathrm{~m}, 3 \mathrm{H}), 4.19(\mathrm{t}$, $J=11.8 \mathrm{~Hz}, 2 \mathrm{H}), 3.92(\mathrm{~s}, 3 \mathrm{H}), 3.78(\mathrm{t}, J=12.6 \mathrm{~Hz}, 2 \mathrm{H}), 2.35-2.26(\mathrm{~m}, 2 \mathrm{H})$. 
6-(3-Chloropropoxy)-3-(4-methoxyphenyl)-2H-chromen-2-one (31). Using the previous procedure and starting from 6-hydroxy-3-(4-methoxyphenyl)-2H-chromen-2-one, 31 was obtained. Yield $49 \%$, mp 114-116 ${ }^{\circ} \mathrm{C} .{ }^{1} \mathrm{H}$ NMR 7.89 (s, 1H), 7.64 (d, J=8.8 Hz, 2H), 7.49-7.31 (m, 3H), 7.08-6.91 (m, 2H), $4.19(\mathrm{t}, J=11.8 \mathrm{~Hz}, 2 \mathrm{H}), 3.95(\mathrm{~s}, 3 \mathrm{H}), 3.78(\mathrm{t}, J=12.6 \mathrm{~Hz}, 2 \mathrm{H}), 2.35-2.26(\mathrm{~m}$, $2 \mathrm{H})$.

3-(4-Chlorophenyl)-7-(3-chloropropoxy)-2H-chromen-2-one (32). Using the previous procedure and starting from 3-(4-chlorophenyl)-7-hydroxy-2H-chromen-2-one, 32 was obtained. Yield $74 \%$, mp 157-158 ${ }^{\circ} \mathrm{C} .{ }^{1} \mathrm{H}$ NMR $\delta 7.76(\mathrm{~s}, 1 \mathrm{H}), 7.66(\mathrm{~d}, J=8.4 \mathrm{~Hz}, 2 \mathrm{H}), 7.46-7.40(\mathrm{~m}, 3 \mathrm{H})$, 6.89-6.87 (m, 2H), 4.22-4.18 (m, 2H), 3.79-3.75 (m, 2H), 2.31-2.26 (m, 2H).

7-(3-Chloropropoxy)-2H-chromen-2-one (33). Using the previous procedure and starting from 7hydroxycoumarin, $\mathbf{3 3}$ was obtained. ${ }^{17}$

8-(3-Chloropropoxy)-5H-chromeno[2,3-b]pyridin-5-one (34). Using the previous procedure and starting from 8-hydroxy-5H-chromeno[2,3-b]pyridin-5-one, $\mathbf{3 4}$ was obtained. ${ }^{17}$

7-((5-Chloropentyl)oxy)-2H-chromen-2-one (35). Using the previous procedure and starting from 7-hydroxycoumarin and 1-bromo-5-chloropentane, 35 was obtained. Yield 51.2 \%, mp 52-54 ${ }^{\circ} \mathrm{C}$. ${ }^{1} \mathrm{H}$ NMR $\delta 7.60(\mathrm{~d}, J=9.5 \mathrm{~Hz}, 1 \mathrm{H}), 7.33(\mathrm{~d}, J=8.6 \mathrm{~Hz}, 1 \mathrm{H}), 6.80(\mathrm{dd}, J=8.6$ and $2.4 \mathrm{~Hz}, 1 \mathrm{H})$, $6.76(\mathrm{~d}, J=2.3 \mathrm{~Hz}, 1 \mathrm{H}), 6.20(\mathrm{~d}, J=9.5 \mathrm{~Hz}, 1 \mathrm{H}), 4.13(\mathrm{t}, J=5.8 \mathrm{~Hz}, 2 \mathrm{H}), 3.71(\mathrm{t}, J=6.3 \mathrm{~Hz}, 2 \mathrm{H})$, 1.98-1.89 (m, 4H), 1.69-1.68 (m, 2H).

3-((5-Chloropentyl)oxy)-7,8,9,10-tetrahydro-6H-benzo[c]chromen-6-one (36). Using the previous procedure and starting from 3-hydroxy-7,8,9,10-tetrahydro-6H-benzo[c]chromen-6-one and 1-bromo-5-chloropentane, 36 was obtained. Yield $96 \%$, yellow oil. ${ }^{1} \mathrm{H}$ NMR $\delta 7.38(\mathrm{~d}, J=8.8$ $\mathrm{Hz}, 1 \mathrm{H}), 6.76(\mathrm{~d}, J=8.8 \mathrm{~Hz}, 1 \mathrm{H}), 6.70(\mathrm{~s}, 1 \mathrm{H}), 3.94(\mathrm{t}, J=12.4 \mathrm{~Hz}, 2 \mathrm{H}), 3.50(\mathrm{t}, J=12.8 \mathrm{~Hz}, 2 \mathrm{H})$, 2.67-2.56 (m, 2H), 2.49-2.48 (m, 2H), 1.83-1.61 (m, 8H), 1.55-1.52 (m, 2H).

8-((5-Chloropentyl)oxy)-5H-chromeno[2,3-b]pyridin-5-one (37). Using the previous procedure and starting from 8-hydroxy-5H-chromeno[2,3-b]pyridin-5-one and 1-bromo-5-chloropentane, 37 was obtained. Yield $68 \%$, mp 109-110 ${ }^{\circ} \mathrm{C} .{ }^{1} \mathrm{H}$ NMR $\delta 8.72-8.69(\mathrm{~m}, 2 \mathrm{H}), 8.24(\mathrm{dd}, J=7.6 \mathrm{~Hz}, 1 \mathrm{H})$, 
$7.45(\mathrm{~d}, J=11.8 \mathrm{~Hz}, 1 \mathrm{H}), 6.99(\mathrm{~d}, J=11.8 \mathrm{~Hz}, 2 \mathrm{H}), 4.12(\mathrm{t}, J=12.8 \mathrm{~Hz}, 2 \mathrm{H}), 3.61(\mathrm{t}, J=13.2 \mathrm{~Hz}$, 2H), $1.92-1.87(\mathrm{~m}, 4 \mathrm{H}), 1.69-1.68(\mathrm{~m}, 2 \mathrm{H})$.

General method for the preparation of iodo derivatives (38-49). A mixture of the selected chloro derivative $(1.0 \mathrm{mmol})$ and $\mathrm{NaI}(1.0 \mathrm{mmol})$ in methyl ethyl ketone $(15 \mathrm{~mL})$ was refluxed for $3 \mathrm{~h}$, then it was concentrated under reduced pressure. The crude was dissolved in DCM and washed with water. The organic layer was evaporated under reduced pressure, affording compounds 38-49 that were used for the next reaction without any further purification.

7-(3-((3-Hydroxybenzyl)(methyl)amino)propoxy)-4-methyl-2H-chromen-2-one (50). A mixture of 38 (1.53 g, $4.46 \mathrm{mmol}), 3-(($ methylamino)methyl)phenol (0.61 g, $4.46 \mathrm{mmol})$ and TEA (0,404 g, $4.46 \mathrm{mmol})$ in toluene $(20 \mathrm{~mL})$ was refluxed for $24 \mathrm{~h}$. The organic phase was washed with water, dried and concentrated under reduced pressure. The crude was purified by flash column chromatography (toluene/acetone 3:2), affording $\mathbf{5 0}(0.44 \mathrm{~g}, 28 \%)$, mp 133-135 ${ }^{\circ} \mathrm{C} .{ }^{1} \mathrm{H} \mathrm{NMR} \delta$ $7.58(\mathrm{~d}, J=8.2 \mathrm{~Hz}, 1 \mathrm{H}), 7.15(\mathrm{t}, J=15.6 \mathrm{~Hz}, 1 \mathrm{H}), 6.95-6.79(\mathrm{~m}, 5 \mathrm{H}), 6.15(\mathrm{~s}, 1 \mathrm{H}), 4.19(\mathrm{t}, J=11.2$ $\mathrm{Hz}, 2 \mathrm{H}), 3.50(\mathrm{~s}, 2 \mathrm{H}), 2.63-2.58(\mathrm{~m}, 2 \mathrm{H}), 2.45(\mathrm{~s}, 3 \mathrm{H}), 2.25(\mathrm{~s}, 3 \mathrm{H}), 2.15-1.89(\mathrm{~m}, 2 \mathrm{H})$.

3-(3-((3-Hydroxybenzyl)(methyl)amino)propoxy)-7,8,9,10-tetrahydro-6H-benzo[c]chromen-6one (51). Using the previous procedure and starting from 39, 51 was obtained. Yield $41 \%$, purple oil. ${ }^{1} \mathrm{H}$ NMR $\delta 7.44(\mathrm{~d}, J=8.8 \mathrm{~Hz}, 1 \mathrm{H}), 7.14(\mathrm{t}, J=15.6 \mathrm{~Hz}, 1 \mathrm{H}), 6.91-6.79(\mathrm{~m}, 4 \mathrm{H}), 6.77-6.75(\mathrm{~m}$, 1H), $4.07(\mathrm{t}, J=11.8 \mathrm{~Hz}, 2 \mathrm{H}), 3.45(\mathrm{~s}, 2 \mathrm{H}), 2.57(\mathrm{t}, J=11.6 \mathrm{~Hz}, 2 \mathrm{H}), 2.57-2.52(\mathrm{~m}, 4 \mathrm{H}), 2.23(\mathrm{~s}$, $3 \mathrm{H}), 2.00-1.94(\mathrm{~m}, 2 \mathrm{H}), 1.86-1.78(\mathrm{~m}, 4 \mathrm{H})$.

3-(3-((3-Hydroxybenzyl)(methyl)amino)propoxy)-6H-benzo[c]chromen-6-one (52). Using the previous procedure and starting from 40, 52 was obtained. Yield $49 \%$, pale yellow oil. ${ }^{1} \mathrm{H}$ NMR $\delta$ $8.35(\mathrm{~d}, J=8.8 \mathrm{~Hz}, 1 \mathrm{H}), 8.11-7.95(\mathrm{~m}, 2 \mathrm{H}), 7.83(\mathrm{t}, J=8.2 \mathrm{~Hz}, 1 \mathrm{H}), 7.55(\mathrm{t}, J=8.1 \mathrm{~Hz}, 1 \mathrm{H}), 7.22-$ $7.09(\mathrm{~m}, 3 \mathrm{H}), 6.95-6.72(\mathrm{~m}, 3 \mathrm{H}), 4.09(\mathrm{t}, J=11.2 \mathrm{~Hz}, 2 \mathrm{H}), 3.45(\mathrm{~s}, 2 \mathrm{H}), 2.5-2.33(\mathrm{~m}, 2 \mathrm{H}), 2.15(\mathrm{~s}$, $3 \mathrm{H}), 2.05-1.89(\mathrm{~m}, 2 \mathrm{H})$.

7-(3-((3-Hydroxybenzyl)(methyl)amino)propoxy)-3-phenyl-2H-chromen-2-one (53). Using the previous procedure and starting from 41, 53 was obtained. Yield $85 \%$, colorless oil. ${ }^{1} \mathrm{H}$ NMR $\delta$ 
$7.77(\mathrm{~s}, 1 \mathrm{H}), 7.71(\mathrm{~d}, J=8.8 \mathrm{~Hz}, 2 \mathrm{H}), 7.48-7.38(\mathrm{~m}, 4 \mathrm{H}), 7.15(\mathrm{t}, J=15.6 \mathrm{~Hz}, 1 \mathrm{H}), 6.92(\mathrm{~d}, J=8$

$\mathrm{Hz}, 2 \mathrm{H}), 6.85(\mathrm{~d}, J=10.4 \mathrm{~Hz}, 2 \mathrm{H}), 6.74(\mathrm{~d}, J=10.4 \mathrm{~Hz}, 1 \mathrm{H}), 4.11(\mathrm{t}, J=12.8 \mathrm{~Hz}, 2 \mathrm{H}), 3.47(\mathrm{~s}$, 2H), $2.55(\mathrm{t}, J=13.4 \mathrm{~Hz}, 2 \mathrm{H}), 2.24(\mathrm{~s}, 3 \mathrm{H}), 2.01(\mathrm{t}, J=13.2 \mathrm{~Hz}, 2 \mathrm{H})$.

7-(3-((3-Hydroxybenzyl)(methyl)amino)propoxy)-3-(4-methoxyphenyl)-2H-chromen-2-one

(54). Using the previous procedure and starting from 42, 54 was obtained. Yield $39 \%$, oil. ${ }^{1} \mathrm{H}$ NMR $\delta$ 7.82-7.78 (m, 3H), $7.42(\mathrm{~d}, J=9.2 \mathrm{~Hz}, 1 \mathrm{H}), 7.17-7.05(\mathrm{~m}, 2 \mathrm{H}), 7.02(\mathrm{~d}, J=8 \mathrm{~Hz}, 2 \mathrm{H}), 6.95-6.76$ $(\mathrm{m}, 5 \mathrm{H}), 4.11(\mathrm{t}, J=12.8 \mathrm{~Hz}, 2 \mathrm{H}), 3.89(\mathrm{~s}, 3 \mathrm{H}), 3.47(\mathrm{~s}, 2 \mathrm{H}), 2.55(\mathrm{t}, J=13.4 \mathrm{~Hz}, 2 \mathrm{H}), 2.24(\mathrm{~s}, 3 \mathrm{H})$, $2.01(\mathrm{t}, J=13.2 \mathrm{~Hz}, 2 \mathrm{H})$.

6-(3-((3-Hydroxybenzyl)(methyl)amino)propoxy)-3-(4-methoxyphenyl)-2H-chromen-2-one (55). Using the previous procedure and starting from 43, 55 was obtained. Yield $37 \%$, oil. ${ }^{1} \mathrm{H}$ NMR $\delta 7.75(\mathrm{~s}, 1 \mathrm{H}), 7.43-7.05(\mathrm{~m}, 5 \mathrm{H}), 6.98-6.65(\mathrm{~m}, 6 \mathrm{H}), 4.14(\mathrm{t}, J=12.8 \mathrm{~Hz}, 2 \mathrm{H}), 3.87(\mathrm{~s}, 3 \mathrm{H}), 3.46(\mathrm{~s}$, 2H), $2.57(\mathrm{t}, J=13.6 \mathrm{~Hz}, 2 \mathrm{H}), 2.22(\mathrm{~s}, 3 \mathrm{H}), 2.07(\mathrm{t}, J=13.2 \mathrm{~Hz}, 2 \mathrm{H})$.

3-(4-Chlorophenyl)-7-(3-((3-hydroxybenzyl)(methyl)amino)propoxy)-2H-chromen-2-one (56).

Using the previous procedure and starting from 44, 56 was obtained. Yield $38 \%, \mathrm{mp} 144-145^{\circ} \mathrm{C}$. ${ }^{1} \mathrm{H}$ NMR $\delta 7.79(\mathrm{~s}, 1 \mathrm{H}), 7.66(\mathrm{~d}, J=8.4 \mathrm{~Hz}, 2 \mathrm{H}), 7.44-7.41(\mathrm{~m}, 4 \mathrm{H}), 7.15(\mathrm{~d}, J=15.6 \mathrm{~Hz}, 1 \mathrm{H}), 6.94$ $(\mathrm{d}, J=14.4 \mathrm{~Hz}, 2 \mathrm{H}), 6.85-6.83(\mathrm{~m}, 2 \mathrm{H}), 4.13(\mathrm{t}, J=12.8 \mathrm{~Hz}, 2 \mathrm{H}), 3.47(\mathrm{~s}, 2 \mathrm{H}), 2.56(\mathrm{t}, J=12.8 \mathrm{~Hz}$ $2 \mathrm{H}), 2.24(\mathrm{~s}, 3 \mathrm{H}), 2.04-2.00(\mathrm{~m}, 2 \mathrm{H})$.

7-(3-((3-Hydroxybenzyl)(methyl)amino)propoxy)-2H-chromen-2-one (57). Using the previous procedure and starting from $\mathbf{4 5 , 5 7}$ was obtained. Yield $31 \%$, brown oil. ${ }^{1} \mathrm{H}$ NMR $\delta 7.65(\mathrm{~d}, J=9.6$ Hz, 1H), $7.36(\mathrm{~d}, J=8.4 \mathrm{~Hz}, 1 \mathrm{H}), 7.26(\mathrm{~s}, 1 \mathrm{H}), 7.13(\mathrm{t}, J=12.8 \mathrm{~Hz}, 1 \mathrm{H}), 6.86-6.79(\mathrm{~m}, 3 \mathrm{H}), 6.75-$ $6.73(\mathrm{~m}, 1 \mathrm{H}), 6.26(\mathrm{~d}, J=9.6 \mathrm{~Hz}, 1 \mathrm{H}), 4.07(\mathrm{t}, J=12.8 \mathrm{~Hz}, 2 \mathrm{H}), 3.46(\mathrm{~s}, 2 \mathrm{H}), 2.55(\mathrm{t}, J=13.4 \mathrm{~Hz}$ 2H), $2.33(\mathrm{t}, J=6.0 \mathrm{~Hz}, 2 \mathrm{H}), 2.24(\mathrm{~s}, 3 \mathrm{H}), 2.01-1.98(\mathrm{~m}, 2 \mathrm{H})$.

8-(3-((3-Hydroxybenzyl)(methyl)amino)propoxy)-5H-chromeno[2,3-b]pyridin-5-one (58). Using the previous procedure and starting from 46, 58 was obtained. Yield $74 \%$, colorless oil. ${ }^{1} \mathrm{H}$ NMR $\delta 8.65(\mathrm{~d}, J=12 \mathrm{~Hz}, 2 \mathrm{H}), 8.13(\mathrm{~d}, J=8.8 \mathrm{~Hz}, 1 \mathrm{H}), 7.39-7.37(\mathrm{~m}, 1 \mathrm{H}), 7.17-7.07(\mathrm{~m}, 3 \mathrm{H})$, 
6.89-6.87 (m, 1H), $6.75(\mathrm{~d}, J=7.2 \mathrm{~Hz}, 1 \mathrm{H}), 6.71(\mathrm{~d}, J=8.0 \mathrm{~Hz}, 1 \mathrm{H}), 4.16(\mathrm{t}, J=12.4 \mathrm{~Hz}, 2 \mathrm{H}), 3.41$ (s, 2H), $2.52(\mathrm{t}, J=13.0 \mathrm{~Hz}, 2 \mathrm{H}), 2.18(\mathrm{~s}, 3 \mathrm{H}), 1.99-1.96(\mathrm{~m}, 2 \mathrm{H})$.

7-((5-((3-Hydroxybenzyl)(methyl)amino)pentyl)oxy)-2H-chromen-2-one (59). Using the previous procedure and starting from 47, 59 was obtained. Yield $18 \%$, oil. ${ }^{1} \mathrm{H}$ NMR $\delta 7.60(\mathrm{~d}, J=$ $9.5 \mathrm{~Hz}, 1 \mathrm{H}), 7.33(\mathrm{~d}, J=8.6 \mathrm{~Hz}, 1 \mathrm{H}), 7.25-7.11(\mathrm{~m}, 1 \mathrm{H}), 6.79-6.68(\mathrm{~m}, 5 \mathrm{H}), 6.20(\mathrm{~d}, J=9.5 \mathrm{~Hz}$, $1 \mathrm{H}), 4.13(\mathrm{t}, J=5.8 \mathrm{~Hz}, 2 \mathrm{H}), 3.71(\mathrm{t}, J=6.3 \mathrm{~Hz}, 2 \mathrm{H}), 3.44(\mathrm{~s}, 2 \mathrm{H}), 2.24(\mathrm{~s}, 3 \mathrm{H}), 1.98-1.89(\mathrm{~m}, 4 \mathrm{H})$, $1.69-1.68(\mathrm{~m}, 2 \mathrm{H})$.

3-((5-((3-Hydroxybenzyl)(methyl)amino)pentyl)oxy)-7,8,9,10-tetrahydro-6Hbenzo[c]chromen-6-one (60). Using the previous procedure and starting from 48, 60 was obtained. Yield $37 \%$, yellow oil. ${ }^{1} \mathrm{H}$ NMR $\delta .42(\mathrm{~d}, J=8.8 \mathrm{~Hz}, 1 \mathrm{H}), 7.14(\mathrm{t}, J=8.0 \mathrm{~Hz}, 1 \mathrm{H}), 6.85-6.78(\mathrm{~m}$, 3H), $6.73(\mathrm{dd}, J=10.2$ and $2.0 \mathrm{~Hz}, 2 \mathrm{H}), 3.96(\mathrm{t}, J=6.5 \mathrm{~Hz}, 2 \mathrm{H}), 3.45(\mathrm{~s}, 2 \mathrm{H}), 2.74(\mathrm{t}, J=5.8 \mathrm{~Hz}$, 2H), $2.55(\mathrm{t}, J=5.7 \mathrm{~Hz}, 2 \mathrm{H}), 2.47-2.38(\mathrm{~m}, 2 \mathrm{H}), 2.21(\mathrm{~s}, 3 \mathrm{H}), 1.88-1.73(\mathrm{~m}, 6 \mathrm{H}), 1.58(\mathrm{dd}, J=14.8$ and $7.6 \mathrm{~Hz}, 2 \mathrm{H}), 1.48(\mathrm{dd}, J=14.9$ and $7.9 \mathrm{~Hz}, 2 \mathrm{H})$.

8-((5-((3-Hydroxybenzyl)(methyl)amino)pentyl)oxy)-5H-chromeno[2,3-b]pyridin-5-one (61). Using the previous procedure and starting from 49, 61 was obtained. Yield $64 \%$, yellow oil. ${ }^{1} \mathrm{H}$ NMR $\delta 8.72(\mathrm{~d}, J=6.4 \mathrm{~Hz}, 2 \mathrm{H}), 8.21(\mathrm{~d}, J=8.8 \mathrm{~Hz}, 1 \mathrm{H}), 7.45(\mathrm{~d}, J=5.2 \mathrm{~Hz}, 1 \mathrm{H}), 7.26(\mathrm{~s}, 1 \mathrm{H})$, $7.16(\mathrm{t}, J=15.6 \mathrm{~Hz}, 1 \mathrm{H}), 6.97-6.93(\mathrm{~m}, 2 \mathrm{H}), 6.84(\mathrm{~d}, J=7.2 \mathrm{~Hz}, 1 \mathrm{H}), 6.78(\mathrm{~d}, J=9.6 \mathrm{~Hz}, 1 \mathrm{H}), 4.06$ $(\mathrm{t}, J=12.8 \mathrm{~Hz}, 2 \mathrm{H}), 3.49(\mathrm{~s}, 2 \mathrm{H}), 2.45(\mathrm{~d}, J=13.2 \mathrm{~Hz}, 2 \mathrm{H}), 2.25(\mathrm{~s}, 3 \mathrm{H}), 1.87-1.79(\mathrm{~m}, 2 \mathrm{H}), 1.66$ $(\mathrm{m}, 2 \mathrm{H}), 1.55-1.48(\mathrm{~m}, 2 \mathrm{H})$.

7-(Prop-2-yn-1-yloxy)-2H-chromen-2-one (62). To a solution of 7-hydroxycoumarin (1.00 g, 6.17 $\mathrm{mmol})$ in acetone $(40 \mathrm{~mL})$, propargyl bromide $(0.88 \mathrm{~g}, 7.40 \mathrm{mmol})$ and anhydrous $\mathrm{K}_{2} \mathrm{CO}_{3}(1.00 \mathrm{~g})$ were added. The mixture was refluxed for $8 \mathrm{~h}$, then it was hot filtered and concentrated under reduced pressure. The crude was crystallized with petroleum ether, affording $1.22 \mathrm{~g}(97 \%)$ of $\mathbf{6 2}$, mp 120-121 ${ }^{\circ} \mathrm{C} .{ }^{1} \mathrm{H}$ NMR $\delta 7.26(\mathrm{~d}, J=9.5 \mathrm{~Hz}, 1 \mathrm{H}), 7.01(\mathrm{~d}, J=8.5 \mathrm{~Hz}, 1 \mathrm{H}), 6.87(\mathrm{~s}, 1 \mathrm{H}), 6.56(\mathrm{~d}$, $J=2.3 \mathrm{~Hz}, 1 \mathrm{H}), 6.52(\mathrm{dd}, J=8.5$ and $2.4 \mathrm{~Hz}, 1 \mathrm{H}), 5.89(\mathrm{~d}, J=9.5 \mathrm{~Hz}, 1 \mathrm{H}), 4.37(\mathrm{~d}, J=2.4 \mathrm{~Hz}$, $2 \mathrm{H}), 2.19(\mathrm{t}, J=2.4 \mathrm{~Hz}, 1 \mathrm{H})$. 


\section{7-((1-(4-Methoxybenzyl)-1H-1,2,3-triazol-4-yl)methoxy)-2H-chromen-2-one (63a). To a}

solution of $62(0.50 \mathrm{~g}, 2.49 \mathrm{mmol})$ in DMSO $(15 \mathrm{~mL}), 1$-(azidomethyl)-4-methoxybenzene $(0.53 \mathrm{~g}$, $3.24 \mathrm{mmol}$, see SI) and TEA $(0.02 \mathrm{~g}, 0.25 \mathrm{mmol})$ were added. $\mathrm{CuSO}_{4}(0.04 \mathrm{~g}, 0.25 \mathrm{mmol})$ and sodium ascorbate $(0.25 \mathrm{~g}, 1.25 \mathrm{mmol})$ were dissolved in water and were stirred for $5 \mathrm{~min}$; this solution was added to the reaction flask and the mixture was stirred at $\mathrm{rt}$ for $24 \mathrm{~h}$. A saturated solution of $\mathrm{NH}_{4} \mathrm{Cl}$ was added to the reaction mixture, that was then extracted with ethyl acetate. The solvent was removed and the crude mixture was purified by flash column chromatography (toluene/acetone 4:1), affording $0.89 \mathrm{~g}$ (yield $98 \%$ ) of 63a, mp $134-136{ }^{\circ} \mathrm{C} .{ }^{1} \mathrm{H} \mathrm{NMR}(200 \mathrm{MHz}$, $\left.\mathrm{CDCl}_{3},\right) \delta 7.63(\mathrm{~d}, J=9.4 \mathrm{~Hz}, 1 \mathrm{H}), 7.54(\mathrm{~s}, 1 \mathrm{H}), 7.37(\mathrm{~d}, J=8.4 \mathrm{~Hz}, 1 \mathrm{H}), 7.25(\mathrm{~d}, J=8.4 \mathrm{~Hz}, 2 \mathrm{H})$, 6.93-6.87 (m, 4H), $6.26(\mathrm{~d}, J=9.4 \mathrm{~Hz}, 1 \mathrm{H}), 5.48(\mathrm{~s}, 2 \mathrm{H}), 5.22(\mathrm{~s}, 2 \mathrm{H}), 3.81(\mathrm{~s}, 3 \mathrm{H})$.

7-((1-(3-Methoxybenzyl)-1H-1,2,3-triazol-4-yl)methoxy)-2H-chromen-2-one (63b). Using the previous procedure and starting from 62 and 1-(azidomethyl)-3-methoxybenzene (see SI), $63 \mathbf{b}$ was obtained. Yield $95 \%, \mathrm{mp} 101-102{ }^{\circ} \mathrm{C} .{ }^{1} \mathrm{H}$ NMR $\delta$ 7.61-7.69 (m, 2H), $7.33(\mathrm{~d}, J=8.4 \mathrm{~Hz}, 1 \mathrm{H}), 7.25$ $(\mathrm{t}, J=15.6 \mathrm{~Hz}, 1 \mathrm{H}), 6.88-6.76(\mathrm{~m}, 4 \mathrm{H}), 6.20(\mathrm{~d}, J=9.6 \mathrm{~Hz}, 1 \mathrm{H}), 5.47(\mathrm{~s}, 2 \mathrm{H}), 5.18(\mathrm{~s}, 2 \mathrm{H}), 3.73(\mathrm{~s}$, $3 \mathrm{H})$.

\section{7-((1-(4-Hydroxybenzyl)-1H-1,2,3-triazol-4-yl)methoxy)-2H-chromen-2-one (64a). To a} solution of $63 \mathbf{a}(0.89 \mathrm{~g}, 2.45 \mathrm{mmol})$ in anhydrous dichloromethane $(50 \mathrm{~mL})$ kept at $0{ }^{\circ} \mathrm{C}$, under nitrogen atmosphere, $\mathrm{BBr}_{3}(4.0 \mathrm{~mL}$ of $1 \mathrm{M}$ solution in $\mathrm{DCM})$ was added dropwise and the mixture was stirred at $\mathrm{rt}$ for $48 \mathrm{~h}$. The reaction was quenched with water and washed with brine. The organic layer was concentrated under reduced pressure. The crude was purified by flash column chromatography (toluene/acetone 4:1), affording $0.32 \mathrm{~g}(37 \%)$ of $\mathbf{6 4 a}$ as a yellow oil. ${ }^{1} \mathrm{H}$ NMR $\delta$ $7.49(\mathrm{~d}, J=9.4 \mathrm{~Hz}, 1 \mathrm{H}), 7.54(\mathrm{~s}, 1 \mathrm{H}), 7.37(\mathrm{~d}, J=8.4 \mathrm{~Hz}, 1 \mathrm{H}), 7.18(\mathrm{~d}, J=8.4 \mathrm{~Hz}, 2 \mathrm{H}), 6.88(\mathrm{~m}$, $4 \mathrm{H}), 6.26(\mathrm{~d}, J=9.4 \mathrm{~Hz}, 1 \mathrm{H}), 5.98(\mathrm{~s}, 1 \mathrm{H}), 5.46(\mathrm{~s}, 2 \mathrm{H}), 5.21(\mathrm{~s}, 2 \mathrm{H})$.

7-((1-(3-Hydroxybenzyl)-1H-1,2,3-triazol-4-yl)methoxy)-2H-chromen-2-one (64b). Using the previous procedure and starting from $\mathbf{6 3 b}, \mathbf{6 4 b}$ was obtained. Yield $21 \%, \mathrm{mp} 65-66{ }^{\circ} \mathrm{C} .{ }^{1} \mathrm{H} \mathrm{NMR} \delta$ 
7.61-7.59 (m, 2H), $7.34(\mathrm{~d}, J=11.2 \mathrm{~Hz}, 1 \mathrm{H}), 7.24(\mathrm{t}, 1 \mathrm{H}, J=15.2), 6.87-6.84(\mathrm{~m}, 4 \mathrm{H}), 6.24(\mathrm{~d}, J=$ $9.4 \mathrm{~Hz}, 1 \mathrm{H}), 5.47(\mathrm{~s}, 2 \mathrm{H}), 5.18(\mathrm{~s}, 2 \mathrm{H})$.

\section{7-((1-(4-Hydroxyphenyl)-1H-1,2,3-triazol-4-yl)methoxy)-2H-chromen-2-one (65a). To a}

solution of $62(0.43 \mathrm{~g}, 2.16 \mathrm{mmol})$ in DMSO $(15 \mathrm{~mL})$, (4-azidophenoxy)-(tert-butyl)dimethylsilane $\left(0.70 \mathrm{~g}, 2.81 \mathrm{mmol}\right.$, see SI) and TEA $(0.02 \mathrm{~g}, 0.216 \mathrm{mmol})$ were added. $\mathrm{CuSO}_{4}(0.04 \mathrm{~g}, 0.22 \mathrm{mmol})$ and sodium ascorbate $(0.25 \mathrm{~g}, 1.08 \mathrm{mmol})$ were dissolved in water and were stirred for $5 \mathrm{~min}$; the solution was added to the reaction flask and the mixture was stirred at $\mathrm{rt}$ for $24 \mathrm{~h}$. A saturated solution of $\mathrm{NH}_{4} \mathrm{Cl}$ was added to the reaction and the organic compound was extracted with ethyl acetate. The 1H NMR spectrum of the crude product confirmed that the reaction had occurred. The mixture was purified by flash column chromatography (toluene/acetone 4:1). During purification the molecule was deprotected, therefore peaks corresponding to the TBDMS groups disappeared from the NMR spectrum. 65a $(0.18 \mathrm{~g}, 25 \%)$ was obtained, mp $239-240{ }^{\circ} \mathrm{C} .{ }^{1} \mathrm{H}$ NMR (DMSO- $\left.d_{6}\right) \delta$ $9.97(\mathrm{~s}, 1 \mathrm{H}), 8.81(\mathrm{~s}, 1 \mathrm{H}), 8.00(\mathrm{~d}, J=9.5 \mathrm{~Hz}, 1 \mathrm{H}), 7.66(\mathrm{dd}, J=8.8$ and $2.6 \mathrm{~Hz}, 2 \mathrm{H}), 7.19(\mathrm{~s}, 1 \mathrm{H})$, $7.06(\mathrm{~d}, J=8.7 \mathrm{~Hz}, 1 \mathrm{H}), 6.93(\mathrm{~d}, J=8.7 \mathrm{~Hz}, 2 \mathrm{H}), 6.31(\mathrm{~d}, J=9.6 \mathrm{~Hz}, 1 \mathrm{H}), 5.33(\mathrm{~s}, 2 \mathrm{H})$.

7-((1-(3-Hydroxyphenyl)-1H-1,2,3-triazol-4-yl)methoxy)-2H-chromen-2-one (65b). Using the previous procedure and starting from 62 and (3-azidophenoxy)-(tert-butyl)dimethylsilane (see SI), 65b was obtained. Yield $63 \%, \mathrm{mp} 218-219{ }^{\circ} \mathrm{C} .{ }^{1} \mathrm{H}$ NMR (DMSO-d $) \delta 10.07(\mathrm{~s}, 1 \mathrm{H}), 8.94(\mathrm{~s}, 1 \mathrm{H}$ ), $8.01(\mathrm{~d}, J=9.5 \mathrm{~Hz}, 1 \mathrm{H}), 7.66(\mathrm{~d}, J=8.6 \mathrm{~Hz}, 1 \mathrm{H}), 7.38(\mathrm{t}, J=8.3 \mathrm{~Hz}, 1 \mathrm{H}), 7.33-7.28(\mathrm{~m}, 2 \mathrm{H}), 7.20$ $(\mathrm{d}, J=1.8 \mathrm{~Hz}, 1 \mathrm{H}), 7.06(\mathrm{dd}, J=8.6,2.0 \mathrm{~Hz}, 1 \mathrm{H}), 6.89(\mathrm{~d}, J=8.1 \mathrm{~Hz}, 1 \mathrm{H}), 6.32(\mathrm{~d}, J=9.5 \mathrm{~Hz}$, 1H), $5.34(\mathrm{~s}, 2 \mathrm{H})$.

\section{Biological evaluation methods.}

Inhibition of AChE and BuChE. The capacity of 2-17 and 18-25 to inhibit human ChE activity was assessed using the Ellman's method. ${ }^{19}$ Initial rate assays were performed at $37{ }^{\circ} \mathrm{C}$ with a Jasco V-530 double beam spectrophotometer. Stock solutions of the tested compound (1 mM) were 
prepared in methanol and diluted in bidistilled water. The assay solution consisted of a $0.1 \mathrm{M}$ phosphate buffer, $\mathrm{pH} 8.0$, with the addition of $340 \mu \mathrm{M}$ 5,5'-dithiobis(2-nitrobenzoic acid), 0.02 unit/mL human recombinant $\mathrm{AChE}$ or human serum BuChE (Sigma-Aldrich, Italy), and $550 \mu \mathrm{M}$ substrate (acetylthiocholine iodide or butyrylthiocholine iodide, respectively (Sigma -Aldrich, Italy). Assay solutions with and without inhibitor were preincubated at $37{ }^{\circ} \mathrm{C}$ for $120 \mathrm{~min}$ in the case of AChE-based assay (for all compounds but 12) and for 15 min (phenylpentyl and phenylhexyl derivatives) or 20 min (heptyl and p-hexyl-phenyl derivatives) in the case of BuChEbased assay followed by the addition of substrate. The proper incubation time was determined on the basis of the kinetic studies in order carbamoylation is completed. AChE inhibition by $\mathbf{1 2}$ was determined after 60 min-incubation. Blank solutions containing all components except AChE or BuChE were prepared in parallel to account for the non enzymatic hydrolysis of the substrate. Five increasing concentrations of the inhibitor, able to give an inhibition of the enzymatic activity in the range of $20-80 \%$, were used. The results were plotted by placing the percentage of inhibition in function of the decimal $\log$ of the final inhibitor concentration. Linear regression and $\mathrm{IC}_{50}$ values were calculated.

Kinetic characterization of carbamoylation events. Tested compounds were added to the assay solution in order to have a final concentration equal to their $\mathrm{IC}_{50}$ values, and preincubated with the enzyme for 15-120 min for AChE-based assays and 2-30 min for BuChE based-assays, followed by the addition of substrate (acetylthiocholine or butyrylthiocholine for $\mathrm{AChE}$ and BuChE, respectively). Assays were performed with a blank containing all components except AChE or BuChE to account for the nonenzymatic reaction. The rate of substrate hydrolysis was determined following Ellman's method. ${ }^{19}$ The percentages of inhibition at different incubation times were plotted vs time (GraphPad Prism, 4.0, GraphPad Software Inc).

Determination of the carbamoylation rate constant $\mathrm{k}_{3}$ for ChE inhibition by 9. 
(a) $h A C h E$. The stopped time assay was performed, in which AChE and $\mathbf{9}$ at five concentrations comprised in the range 16.7-167.5 $\mathrm{nM}$ were mixed in the assay buffer at $\mathrm{pH}$ 8.0. After 15, 30, 60, $90 \& 120$ min incubation at $37^{\circ} \mathrm{C}$, the determination of residual activity of the AChE-catalyzed hydrolysis of acetylthiocholine was carried out by Ellman's method. ${ }^{19}$ A parallel control (i.e., no inhibitors in the mixture) allowed to adjust activities measured at the same incubation times. (b) $h B u C h E$. The stopped time assay was performed, in which BuChE from human serum and 9 at five concentrations comprised in the range $0.46-4.58 \mathrm{nM}$ were mixed in the assay buffer at $\mathrm{pH}$ 8.0. After $1,2,5,10,15 \& 30 \mathrm{~min}$ incubation at $37^{\circ} \mathrm{C}$, the determination of residual activity of the $h$ BuChE-catalyzed hydrolysis of butyrylthiocholine was carried out by Ellman's method. ${ }^{19} \mathrm{~A}$ parallel control (i.e., no inhibitor in the mixture) allowed to adjust activities measured at the same incubation time.

Data were fitted to the following equation ${ }^{27}$

$$
R=R_{0} \exp \left(-k_{\mathrm{obs}} t\right)+R_{\infty}
$$

where $R, R_{0}$, and $\mathrm{R} \propto$ are ratios of the inhibited enzyme activity $\left(v_{\mathrm{i}}\right)$ to the control activity $\left(v_{0}\right)$ at times $t, 0$, and $\infty$, respectively. The values of the observed pseudo-first-order inhibition rate constant $\left(k_{\text {obs }}\right)$ for each concentration of inhibitor were obtained. Double reciprocal plots of $k_{\text {obs }}$ versus inhibitor concentration ([I]) were then used to compute $k_{3}$ from the intercept according to the equation:

$1 / k_{\text {obs }}=K_{d} / k_{3} 1 /[1]+1 / k_{3}$

FAAH assay. The effect of compounds on FAAH activity was detected by co-incubating them with the $10,000 \mathrm{x} g$ membrane fraction of rat brain $(70 \mu \mathrm{g} / \mathrm{sample})$ and synthetic $\mathrm{N}$-arachidonoyl- $\left[{ }^{14} \mathrm{C}\right]-$ ethanolamine (110mCi/mmol, ARC St. Louis, MO, USA) properly diluted with AEA (Tocris Bioscience, Avonmouth, Bristol, UK) in Tris- $\mathrm{HCl} 50 \mathrm{mM}$, at $\mathrm{pH} 9.00-10.00$ at $37^{\circ} \mathrm{C}$ for $30 \mathrm{~min}$. For the pre-incubation protocol, compounds were pre-incubated at various concentrations in the presence of the enzyme $(10,000 \mathrm{x} g$ membrane fraction of rat brain, $70 \mu \mathrm{g} / \mathrm{sample})$ for $20 \mathrm{~min}$ at 37 
${ }^{\circ} \mathrm{C}$. The reaction was then initiated by adding of the substrate. After incubation, the amount of $\left[{ }^{14} \mathrm{C}\right]$-ethanolamine produced was measured by scintillation counting of the aqueous phase after extraction of the incubation mixture with 2 volumes of $\mathrm{CHCl}_{3} / \mathrm{MeOH}$ 1:1 (by vol.). Data are expressed as means \pm SD of at least three separate experiments of the concentration exerting $50 \%$ inhibition of $\left[{ }^{14} \mathrm{C}\right]$-AEA hydrolysis $\left(\mathrm{IC}_{50}\right)$ calculated by fitting sigmoidal concentration response curves by GraphPad.

\section{Computational Studies.}

Molecular modeling studies were performed with the Schrodinger 2014-2 software suite. Ligand molecules were built with Maestro $9.8^{42}$ and prepared with LigPrep $3.0{ }^{43}$ the protein structures were refined with the Protein Preparation Wizard tool. ${ }^{44}$ Induced Fit Docking and Docking studies were conducted with Glide $6.3^{45}$ using the SP scoring function.

Protein preparation. The crystal structure of rat FAAH in its covalent adduct with methylarachidonyl phosphonate (MAP; PDB 1MT5, ${ }^{31}$ chain A and B) was used for Induced Fit Docking studies. The homodimer C- and N-termini were capped with acetyl and methylamino groups, respectively. The bound inhibitor was removed and missing hydrogen atoms were added. The orientation of thiol and hydroxyl groups, the conformations of asparagine, glutamine and histidine residues were adjusted to optimize the overall hydrogen bonding network. Basic and acid amino acids were modeled in their charged form, with the exception of K142, which was maintained neutral. The resulting structure was submitted to a first minimization run with the OPLS2005 force field ${ }^{46}$ in which only hydrogen atoms were free to move. A second minimization was then performed on the whole structure, restraining the position of heavy atoms to an RMSD value of $0.3 \AA$ A. Crystallized water molecules were removed before docking studies. 
The crystal structure of human BuChE in complex with a non covalent inhibitor (PDB 4TPK, ${ }^{36}$ chain A) was used for docking studies. The inhibitor molecule and water molecules were removed and the protein was prepared following the procedure described above.

rFAAH Induced Fit Docking studies. The docking grid was built using Glide 6.3 and was centered on the position of the known FAAH inhibitor 66, setting the dimensions of bounding and enclosing boxes to 26 and $39 \AA$, respectively. As a first step, a softened-potential docking run was performed applying van der Waals radii scaling factors of 0.7 and 0.5 factor on protein and ligand non-polar atoms, respectively. The side chain of residue L278, hindering the accommodation of the aminomethyl linker, was temporarily mutated to alanine. Hydrogen bond constraints were imposed between the carbamate oxygen of the ligands and the backbone nitrogen atoms of I238 and G239, and between the carbamate nitrogen of the ligands and the backbone oxygen atom of M191. The resulting ligand-receptor complexes were then submitted to a protein refinement step. Once the L278 side chain temporarily removed was re-introduced, the amino acids side chains within a shell of $5 \AA$ around the ligands were refined through a conformational search, and the overall complex was minimized. In the last docking step, each ligand structure was optimized in the field of the receptor and scored by applying the default Glide settings. The complexes obtained were finally ranked according to the IFD score, which accounts for the ligand-receptor interaction energy, the solvation terms and the receptor strain. The top-ranked complexes were then evaluated and minimized with the OPLS2005 force field implemented in MacroModel 10.4 ${ }^{47}$ applying the PolakRibiere conjugate gradient method to a convergence threshold of $0.05 \mathrm{~kJ} \mathrm{~mol}^{-1} \AA^{-1}$. During the minimization the ligands and residues within $10 \AA$ from them were free to move, while the backbone of other residues was kept fixed.

hBuChE Docking studies. The docking grid was built using Glide 6.3 and was centered on the position of the co-crystalized inhibitor, setting the dimensions of bounding and enclosing boxes to 16 and $31 \AA$, respectively. A softened-potential docking run was performed by applying a van der 
Waals radii scaling factors of 0.7 and 0.6 factors on protein and on ligands non-polar atoms, respectively. A positional constraint was imposed on the carbamate group, in order to obtain binding poses compatible with the carbamoylation-based mechanism of the ligands. The top-ranked ligand-protein complexes were then submitted to a refinement procedure using the Prime 3.6 implementation. ${ }^{48}$ The amino acid side chains within a shell of $8 \AA$ around the ligands, excepted the residues of the catalytic triad (S198, H438 and E325) and W82, were refined through a conformational search, while each ligand structure was optimized in the field of the receptor and scored by applying the default Glide settings. The complexes obtained were ranked taking into account the ligand-receptor interaction energy, the solvation terms and the receptor strain. The topranked complexes were then evaluated and minimized with the OPLS2005 force field implemented in MacroModel 10.4, applying the Polak-Ribiere conjugate gradient method to a convergence threshold of $0.05 \mathrm{~kJ} \mathrm{~mol}^{-1} \AA^{-} 1$. During the minimization the ligands and residues within $10 \AA$ from them were free to move, while the backbone of other residues was kept fixed.

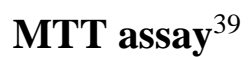

Immortalized SHSY-5Y neuroblastoma cells were purchased from ATCC (Manassas, VA, USA) and routinely grown in Dulbecco's modified Eagle's medium (DMEM) supplemented with 2 mM L-glutamine, $100 \mathrm{U} / \mathrm{ml}$ penicillin $/ 1001 \mathrm{~g} / \mathrm{ml}$ streptomycin and $10 \%$ fetal bovine serum (FBS). Cells were seeded in a 96-well plate at $3.5 \times 10^{4}$ cell/well, and cultured overnight at $37^{\circ} \mathrm{C}$ in a $5 \% \mathrm{CO}_{2}$ atmosphere. Test compounds were incubated in regular media for 24 hours and following incubation, media were replaced with a MTT (Thiazol Blue Tetrazolium Bromide) solution $(0.5 \mathrm{mg} / \mathrm{mL})$ and cultured for additional 3 hours. MTT is taken up into cells by endocytosis or protein-facilitated mechanism and reduced, mainly by mitochondrial enzymes, to yield a purple formazan product which is largely impermeable to cell membranes, thus resulting in its accumulation within living cells (cell lyses results in the liberation of the purple product). Formazan 
(MTT metabolic product) was resuspended by isopropanol and absorbance at $620 \mathrm{~nm}$ was read on a GENios-Pro 96/384 Multifunction Microplate Reader. Optical density values from vehicle-treated cells were considered as $100 \%$ of cell viability and the results were expressed as a percentage (\%) of inhibition of the control (vehicle alone). Data are given as the mean from three independent experiments conducted in quadruplicate. All compounds were dissolved in DMSO and freshly stock solutions were prepared the day of the experiment. The final percentage of solvent used was less than $0.1 \%$ per well.

Supporting Information Available: experimental details for the synthesis of hydroxycoumarins, isocyanates and azides which represent starting material for the synthesis of the new compounds described in Schemes 1 and 2; kinetics of ChE carbamoylation of compounds 12 and 13; binding mode of $\mathbf{9}$ in FAAH; binding mode of $\mathbf{1 0}$ in BuChE. This material is available free of charge via the Internet at http://pubs.acs.org

\section{Author information}

Corresponding Author*

Phone: +39-051-2099710. Fax: +39-051-2099734. E-mail: angela.rampa@unibo.it.

†Present Address: Department for Life Quality Studies, Alma Mater Studiorum University of Bologna, Corso d'Augusto 237, 47921 Rimini, Italy

\section{Notes}

The authors declare no competing financial interest.

Acknowledgements: This research was partially supported by a MERIT grant and by the Italian Ministry for Education, Universities and Research (MIUR). The authors wish to thank Viviana Marolda for her technical assistance with the MTT assay.

\section{Abbreviations used}

$\mathrm{AD}$, Alzheimer's disease; $\mathrm{A} \beta$, amyloid $\beta$ peptide; $\mathrm{AChE}$, acetylcholinesterase, BuChE, butyrylcholinesterase; IL-1, interleukin 1; IL-6, interleukin 6; TNF- $\alpha$, tumor necrosis factor $\alpha$; ROS, reactive oxygen species; ECS, endogenous cannabinoid system; AEA, $N$ - 
arachidonoylethanolamine; 2-AG, 2-arachidonoyl glycerol; $\mathrm{CB}$, cannabinoid receptor; FAAH, fatty acid hydrolase; MAGL, monoacylglycerol lipase; MTDL, multi-target-directed ligand; ACB, acyl chain binding; RMSD, root-mean-square deviation

\section{References}

1. Prince, M.; Jackson, J. World Alzheimer disease report. Alzheimer's Disease International: London, 2009; pp. 25-46.

2. Masters, C. L.; Selkoe, D. J. Biochemistry of amyloid $\beta$-protein and amyloid deposits in Alzheimer Disease. Cold Spring Harb. Perspect. Med. 2012; 2:a006262.

3. Avila, J. Tau phosphorylation and aggregation in Alzheimer's disease pathology. FEBS Lett. 2006, 580, 2922-2927.

4. Bell, K. F.; Cuello, A. C. Altered synaptic function in Alzheimer's disease. Eur. J. Pharmacol. 2006, 545, 11-21.

5. Kanaan, N. M.; Pigino, G. F.; Brady, S. T.; Lazarov, O.; Binder, L. I.; Morfini, G. A. Axonal degeneration in Alzheimer's disease: when signaling abnormalities meet the axonal transport system. Exp. Neurol. 2013, 246, 44-53.

6. Contestabile, A. The history of the cholinergic hypothesis. Behav. Brain Res. 2011, 221, 334-340.

7. Weinstock, M. Selectivity of cholinesterase inhibition: Clinical implications for the treatment of Alzheimer's disease. CNS Drugs 1999, 12, 307-323.

8. Greig, N. H.; Utsuki, T.; Ingram, D. K.; Wang, Y.; Pepeu, G.; Scali, C.; Yu, Q-S.; Mamczarz, J.; Holloway, H. W.; Giordano, T.; Chen, D. M.; Furukawa, K.; Sambamurti, K.; Brossi, A.; Lahiri, D. K. Selective butyrylcholinesterase inhibition elevates brain acetylcholine, augments learning and lowers Alzheimer $\beta$-amyloid peptide in rodent. PNAS 2005, 102, 17213-17218.

9. Fernandez, J. A.; Rojo, L.; Kuljisa, R. O.; Maccioni, R. B. The damage signals hypothesis of Alzheimer's Disease pathogenesis. J. Alzheimer's Dis. 2008, 14, 329-333. 
10. Frank-Cannon, T. C.; Alto, L. T.; McAlpine, F. E.; Tansey, M. G. Does neuroinflammation fan the flame in neurodegenerative diseases? Mol. Neurodegener. 2009, 4, 47.

11. Fagan, S. G.; Campbell, V. A. The influence of cannabinoids on generic traits of neurodegeneration. Br. J. Pharmacol. 2014, 171, 1347-1360.

12. Di Marzo V. Endocannabinoids: synthesis and degradation. Rev. Physiol. Biochem. Pharmacol. 2008, 160, 1-24.

13. Jung, K. M.; Astarita, G.; Yasar, S.; Vasilevko, V.; Cribbs, D. H.; Head, E.; Cotman, C. W.; Piomelli, D. An amyloid $\beta(42)$-dependent deficit in anandamide mobilization is associated with cognitive dysfunction in Alzheimer's disease. Neurobiol. Aging 2012, 33, 1522-1532.

14. Benito, C.; Nunez, E.; Tolon, R. M.; Carrier, E. J.; Rabano, A.; Hillard, C. J.; Romero, J. Cannabinoid CB2 receptors and fatty acid amide hydrolase are selectively overexpressed in neuritic plaque-associated glia in Alzheimer's disease brains. J. Neurosci. 2003, 23, 1113611141.

15. Cavalli, A.; Bolognesi, M. L.; Minarini, A.; Rosini, M.; Tumiatti, V.; Recanatini, M.; Melchiorre, C. Multi-target-directed ligands to combat neurodegenerative diseases. J. Med. Chem. 2008, 51, 347-372.

16. Morphy, R.; Rankovic, Z. Designing multiple ligands - medicinal chemistry strategies and challenges. Curr. Pharm. Des. 2009, 15, 587-600.

17. Rampa, A.; Bartolini, M.; Bisi, A.; Belluti, F.; Gobbi, S.; Andrisano, V.; Ligresti, A.; Di Marzo, V. The first dual ChE/FAAH inhibitors: new perspective for Alzheimer's disease? ACS Med. Chem. Lett. 2012, 3, 182-186.

18. Rampa, A.; Bisi, A.; Valenti, P.; Recanatini, M.; Cavalli, A.; Andrisano, V.; Cavrini, V.; Fin, L.; Buriani, A.; Giusti, P. Acetylcholinesterase inhibitors: synthesis and structureactivity relationships of $\omega$-[N-methyl-N-(3-alkylcarbamoyloxyphenyl)-methyl]aminoalkoxyheteroaryl derivatives. J. Med. Chem. 1998, 41, 3976-3986. 
19. Ellman, G. L.; Courtney, K. D.; Andres, V.; Featherstone, R. M. A new rapid colorimetric determination of acetylcholinesterase activity. Biochem. Pharmacol. 1961, 7, 88-95.

20. Wilson, I. B.; Hatch, M. A.; Ginsburg, S. Carbamylation of acetvlcholinesterase. J. Biol. Chem. 1960, 235, 2312-2315.

21. Wilson, I. B.; Harrison, M. A.; Ginsburg, S. Carbamyl derivatives of acetylcholinesterase. J. Biol. Chem. 1961, 236, 1498-1500.

22. Bolognesi, M. L.; Bartolini, M.; Cavalli, A.; Andrisano, V.; Rosini, M.; Minarini, A.; Melchiorre, C. Design, synthesis, and biological evaluation of conformationally restricted Rivastigmine analogues. J. Med. Chem. 2004, 47, 5945-5952.

23. Marta, M.; Gatta, F.; Pomponi, M. Physostigmine analogs anticholinesterases: effects of the lengthening of the N-carbamic chain on the inhibition kinetics. Biochim. Biophys. Acta 1992, 1120, 262-266.

24. Yu, Q.-S.; Holloway, H. W.; Luo, W.; Lahiri, D. K.; Brossi, A.; Greig, N. H. Long-acting anticholinesterases for myasthenia gravis: synthesis and activities of quaternary phenylcarbamates of neostigmine, pyridostigmine and physostigmine. Bioorg. Med. Chem. 2010, 18, 4687-4693.

25. Mant, T.; Troetel, W. M.; Imbimbo, B. P. Maximum tolerated dose and pharmacodynamics of eptastigmine in elderly healthy volunteers. J. Clin. Pharmacol. 1998, 38, 610-617.

26. Asthana, S.; Greig, N. H.; Hegedus, L.; Holloway, H. H.; Raffaele, K.C.; Schapiro, M. B.; Soncrant, T. T. Clinical pharmacokinetics of physostigmine in patients with Alzheimer's disease. Clin. Pharmacol. Ther. 1995, 58, 299-309.

27. Feaster, R. S.; Quinn, D. M. Mechanism-based inhibitors of mammalian cholesterol esterase. Methods Enzymol. 1997, 286, 231-252.

28. Mor, M.; Lodola, A.; Rivara, S.; Vacondio, F.; Duranti, A.; Tontini, A.; Sanchini, S.; Piersanti, G.; Clapper, J. R.; King, A. R.; Tarzia, G.; Piomelli, D. Synthesis and quantitative 
structure-activity relationship of fatty acid amide hydrolase inhibitors: modulation at the Nportion of biphenyl-3-yl alkylcarbamates. J. Med. Chem. 2008, 51, 3487-3498.

29. Vacondio, F.; Silva, C.; Lodola, A.; Fioni, A.; Rivara, S.; Duranti, A.; Tontini, A.; Sanchini, S.; Clapper, J. R.; Piomelli, D.; Mor, M.; Tarzia, G. Structure-property relationships of a class of carbamate-based fatty acid amide hydrolase (FAAH) inhibitors: chemical and biological stability. ChemMedChem 2009, 4, 1495-1504.

30. Holt, S.; Nilsson, J.; Omeir, R.; Tiger, G.; Fowler, C. J. Effects of pH on the inhibition of fatty acid amidohydrolase by ibuprofen. Br. J. Pharmacol. 2001, 133, 513-520.

31. Lodola, A.; Mor, M.; Rivara, S.; Christov, C.; Tarzia, G; Piomelli, D.; Mulholland, A. J. Identification of productive inhibitor binding orientation in fatty acid amide hydrolase (FAAH) by QM/MM mechanistic modelling. Chem. Commun. 2008, 14, 214-216.

32. Patricelli, M. P.; Lovato, M. A.; Cravatt, B. F. Chemical and mutagenic investigations of fatty acid amide hydrolase: evidence for a family of serine hydrolases with distinct catalytic properties. Biochemistry 1999, 38, 9804-9812.

33. Patricelli, M. P.; Cravatt, B. F. Clarifying the catalytic roles of conserved residues in the amidase signature family. J. Biol. Chem. 2000, 275, 19177-19184.

34. Bracey, M. H.; Hanson, M. A.; Masuda, K. R.; Stevens, R. C.; Cravatt, B. F. Structural adaptations in a membrane enzyme that terminates endocannabinoid signaling. Science 2002, 298, 1793-1796.

35. Nicolet, Y.; Lockridge, O.; Masson, P.; Fontecilla-Camps, J. C.; Nachon, F. Crystal structure of human butyrylcholinesterase and of its complexes with substrate and products. J. Biol. Chem. 2003, 278, 41141-41147.

36. Brus, B.; Košak, U.; Turk, S.; Pišlar, A.; Coquelle, N.; Kos, J.; Stojan, J.; Colletier, J. P.; Gobec, S. Discovery, biological evaluation, and crystal structure of a novel nanomolar selective butyrylcholinesterase inhibitor. J. Med. Chem. 2014, 57, 8167-8179. 
37. Rizzo, S.; Cavalli, A.; Ceccarini, L.; Bartolini, M.; Belluti, F.; Bisi, A.; Andrisano, V.; Recanatini, M.; Rampa, A. Structure-activity relationships and binding mode in the human acetylcholinesterase active site of pseudo-irreversible inhibitors related to xanthostigmine. ChemMedChem 2009, 4, 670-679.

38. Więckowska, A.; Bajda, M.; Guzior, N.; Malawska, B. Novel alkyl- and arylcarbamate derivatives with $\mathrm{N}$-benzylpiperidine and $\mathrm{N}$-benzylpiperazine moieties as cholinesterasesinhibitors. Eur. J. Med. Chem. 2010, 45, 5602-5611.

39. Denizot, F.; Lang, R. Rapid colorimetric assay for cell growth and survival. Modifications to the tetrazolium dye procedure giving improved sensitivity and reliability. J. Immunol. Methods 1986, 89, 271-277.

40. Ghosh, A. K.; Brindisi, M. Organic carbamates in drug design and medicinal chemistry. $J$. Med. Chem. 2015, 58, 2895-2940.

41. Pisani, L.; Catto, M.; Giangreco, I.; Leonetti, F.; Nicolotti, O.; Stefanachi, A.; Cellamare, S.; Carotti, A. Design, synthesis, and biological evaluation of coumarin derivatives tethered to an edrophonium-like fragment as highly potent and selective dual binding site acetylcholinesterase inhibitors. ChemMedChem 2010, 5, 1616-1630.

42. Maestro, version 9.8, Schrödinger, LLC, New York, NY, 2014.

43. LigPrep, version 3.0, Schrödinger, LLC, New York, NY, 2014.

44. a) Schrödinger Suite 2014-2 Protein Preparation Wizard; b) Epik version 2.8, Schrödinger, LLC, New York, NY, 2014; c) Impact version 6.3, Schrödinger, LLC, New York, NY, 2014; d) Prime version 3.6, Schrödinger, LLC, New York, NY, 2014.

45. Glide, version 6.3, Schrödinger, LLC, New York, NY, 2014.

46. Jorgensen, W. L.; Maxwell, D. S.; Tirado-Rives, J. Development and testing of the OPLS all-atom force field on conformational energetics and properties of organic liquids. J. Am. Chem. Soc. 1996, 118, 11225-11236.

47. Macromodel, version 10.4, Schrödinger, LLC, New York, NY, 2014. 
48. Prime version 3.6, Schrödinger, LLC, New York, NY, 2014. 
Table of Contents Graphic

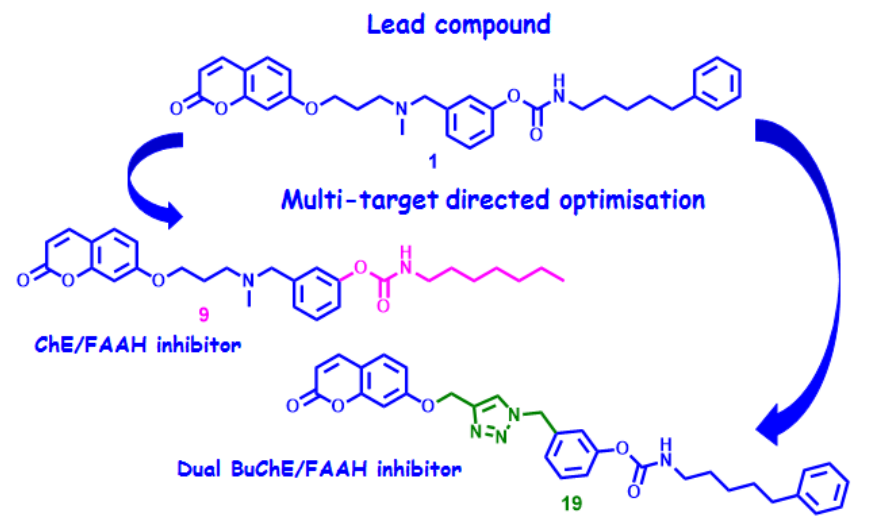

